GUILHERME MARCELLO QUEIROGA CRUZ

\author{
DESVENDANDO AS INTERAÇÕES ENTRE \\ RETROTRANSPOSONS E GENOMAS VEGETAIS, \\ COM ÊNFASE EM CANA-DE-AÇÚCAR
}

Tese apresentada ao Programa de Pós-Graduação Interunidades em Biotecnologia USP/ Instituto Butantan/ IPT, para obtenção do Título de Doutor em Biotecnologia. 
GUILHERME MARCELLO QUEIROGA CRUZ

\section{DESVENDANDO AS INTERAÇÕES ENTRE RETROTRANSPOSONS E GENOMAS VEGETAIS, COM ÊNFASE EM CANA-DE-AÇÚCAR}

Tese apresentada ao Programa de Pós-Graduação Interunidades em Biotecnologia USP/ Instituto Butantan/ IPT, para obtenção do Título de Doutor em Biotecnologia.

Área de concentração: Biotecnologia

Orientadora: Profa. Dra. Marie-Anne Van Sluys

Versão original 
DADOS DE CATALOGAÇÃO NA PUBLICAÇÃO (CIP)

Serviço de Biblioteca e Informação Biomédica do

Instituto de Ciências Biomédicas da Universidade de São Paulo

(C reprodução total

Cruz, Guilherme Marcello Queiroga.

Desvendando as interações entre retrotransposons e genomas vegetais, com ênfase em cana-de-açúcar / Guilherme Marcello Queiroga Cruz. -- São Paulo, 2014.

Orientador: Profa. Dra. Marie-Anne van Sluys.

Tese (Doutorado) - Universidade de São Paulo. Instituto de Ciências Biomédicas. Programa de Pós-Graduação Interunidades em

Biotecnologia USP/IPT/Instituto Butantan. Área de concentração:

Biotecnologia. Linha de pesquisa: Biologia molecular de plantas.

Versão do título para o inglês: Unraveling the interactions between retrotransposons and plant genomes, with emphasis on sugarcane.

1. Retroelementos 2. Genomas 3. Plantas 4. Saccharum I. Sluys, Profa. Dra. Marie Anne van II. Universidade de São Paulo. Instituto de Ciências Biomédicas. Programa de Pós-Graduação Interunidades em Biotecnologia USP/IPT/Instituto Butantan III. Título. 


\section{UNIVERSIDADE DE SÃO PAULO \\ Programa de Pós-Graduação Interunidades em Biotecnologia}

Universidade de São Paulo, Instituto Butantan, Instituto de Pesquisas Tecnológicas

Candidato(a):

Guilherme Marcello Queiroga Cruz.

Título da Tese:

Desvendando as interações entre retrotransposons e genomas vegetais, com ênfase em cana-de-açúcar .

Orientador(a): $\quad$ Profa. Dra. Marie-Anne van Sluys.

A Comissão Julgadora dos trabalhos de Defesa da Tese de Doutorado, em sessão pública realizada a .................., considerou
( ) Aprovado(a)
( ) Reprovado(a)

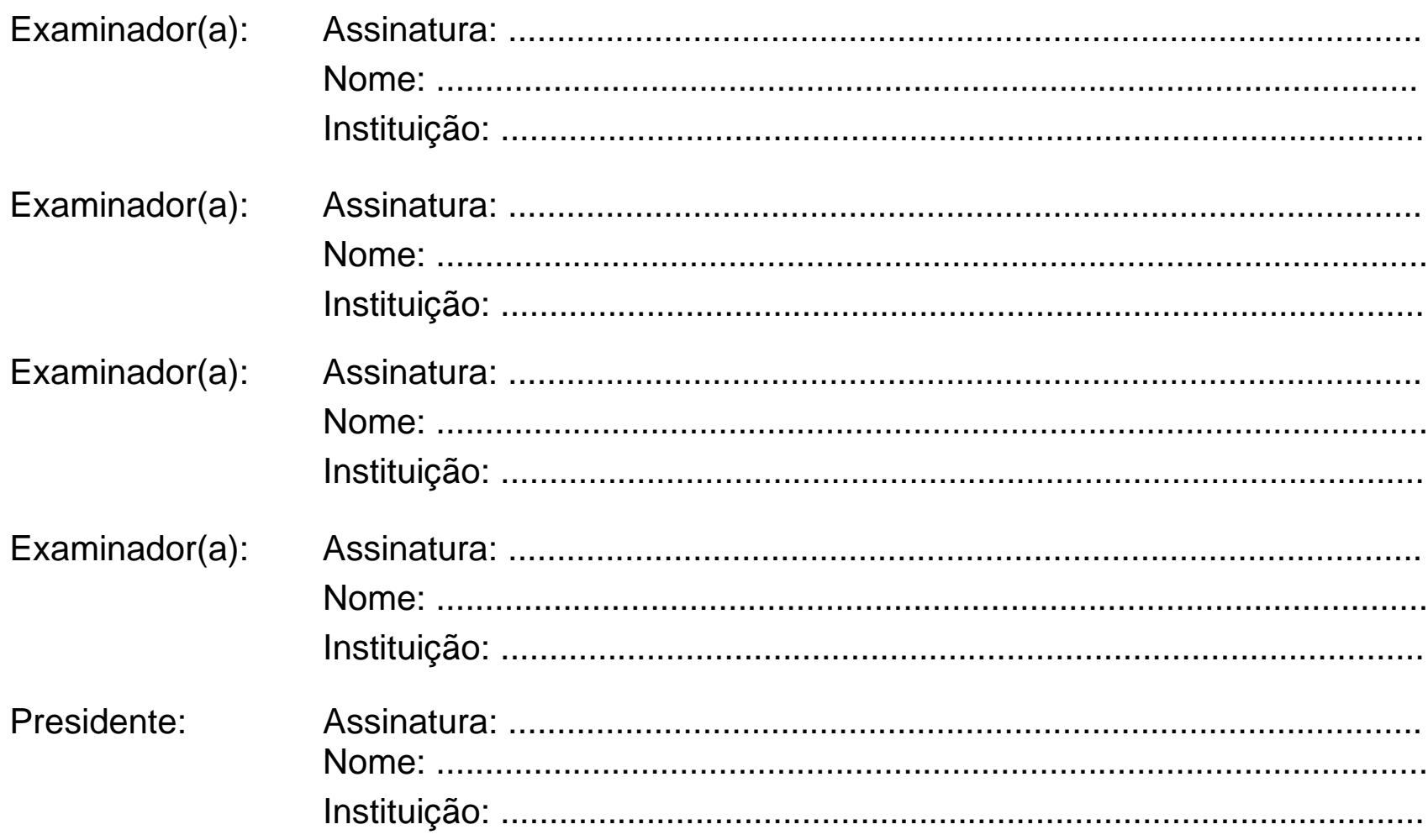


Dedico este trabalho ao meu "Vô Luiz", que de alguma maneira inexplicável já sabia disso tudo. 


\section{AGRADECIMENTOS}

Gostaria de agradecer à Marcia e ao Beto (meus pais), ao Pedro (meu irmão) e a Vó Terezinha (minha avó) pela estrutura, pelo exemplo, pela criação pelas risadas, pela companhia...por fazer de mim a pessoa que sou. E ainda por cima, por aguentar um biólogo falando de transposons na mesa do jantar.

Júlia, obrigado por me acompanhar durante toda esta jornada. Ao longo destes anos todos você me fez uma pessoa melhor. Não consigo imaginar minha vida sem você ao meu lado. Obrigado também por sua ajuda durante a escrita deste documento, você formatou texto, ajudou nas referências, me ensinou português, suportou minhas variações de humor e ainda me alimentou...pode escolher um presente.

Marie, obrigado pela liberdade que me ofereceu para fazer ciência do jeito que conheci no GaTE: motivado pela curiosidade, imaginação e praticamente sem limites. Obrigado também por discordar de mim tantas vezes...é incrível olhar para trás e perceber quantas vezes eu estive errado. Aprendi muito no processo, e se pudesse voltar no tempo seguiria o mesmo caminho (GaTE para sempre).

Amigos do laboratório, muitas passaram pelas bancadas ao meu redor. Todas contribuíram para que a minha passagem pelo GaTE Lab fosse tão agradável, que sair de lá foi dolorido. Para não ser injusto com ninguém, vou citá-los em ordem alfabética: Alessandro Varani, Ana Paula Pimentel Costa, Andréia Prata, Bruno Karolski, Cushla Jane Metcalfe, Daniela Kajihara, Daniela Milstein, Danielle Quitanilha, Douglas Domingues, Edgrar Andrés Ochoa Cruz, Eduardo Abrantes, Erika Maria de Jesus, Fabiana Godoy, Gesiele Barros, Hana Masuda, Jonas Gaiarsa, Juliana Almeida, Juliana Nico, Juliane ishida, Leonor, Luiza Fernanda Bermudez, Magdalena Rossi, Marcelo Zerilo, Maria Eliza Manetti, Marisa Momoli, Mayra Kuroki, Myna Nakabashi, Nathalia de Setta, Nilo Saccaro, Oberdan Cunha Lima, Robson Francisco de Souza, Rosário Medina, Sárah Oliveira, Silvia Blanco, Tatiana Correia, Verônica Gairsa. Deixo para trás só boas lembranças, e levo a amizade de vocês comigo.

Preciso agradecer a algumas pessoas que foram tutores, parceiros e extremamente pacientes comigo. Myna, por me ensinar a trabalhar como um biólogo e como apagar pequenos incêndios; Douglas, por ser um exemplo e um grande parceiro, quando eu cescer quero ser como você; Cushla, for all the help correcting my engish and being a partner in so many occasions; Jones, por manter a impressora funcionando; Tati, obrigado por salvar minha vida diversas vezes; Andréia, por ser o meu dedão esquerdo durante meses tão doloridos; 
Bruno Karolski, por encher o ambiente com a sua risada...ninguém ri melhor que o Bruno; Andres, tão parecido comigo e tão diferente, obrigado pela parceria...na bancada e fora dela.

Minha passagem pelo laboratório não seria a mesma sem as colaborações que tive a sorte de concretizar. Agradeço aos meus amigos Paula Elbl e José Hernandes, por toda ajuda com o estranho e fascinante mundo da anatomia vegetal. Agradeço ao Fábio Tebaldi Nogueira e ao Renato Vicentini pela interessantíssima colaboração com pequenos RNAs. Agradeço também a Raquel Kriedt, por me apresentar aos curiosos transposons de petúnias.

Amigos da Bio, sempre companheiros, estiveram sempre ao meu lado...mesmo quando estavam do outro lado do mundo. Todos mudaram a minha vida, todos fazem parte desta tese. Deixo um agradecimento especial para a turma do "Brunch" (Lui, Thali e Burso) que por tantos anos foram os meus fiéis companheiros de almoço. Encontro vocês mais tarde no “Green”.

Agradeço a todos do Ataliba Handball Mamute, pois quando minhas PCRs falhavam vocês me proporcionaram a melhor das terapias: a Muêção. Na próxima encarnação quero nascer Mamute.

Agradeço à Fundação de Amparo à Pesquisa do Estado de São Paulo (FAPESP), que financiou meu projeto através da bolsa de doutorado número 2008/58243-8. 
"I am enough of an artist to draw freely upon my imagination. Imagination is more important than knowledge. Knowledge is limited. Imagination encircles the world."

- Albert Einstein (1929) 


\section{RESUMO}

CRUZ, G. M. Q. Desvendando as interações entre retrotransposons e genomas vegetais, com ênfase em cana-de-açúcar. 2014. 94 f. Tese (Doutorado em Biotecnologia) - Instituto de Ciências Biomédicas, Universidade de São Paulo, São Paulo, 2014.

Esta tese é estruturada em dois capítulos. O primeiro capítulo explora os retrotransposons com LTR (LTR-RT) em cana-de-açúcar e grande parte de seus resultados foram publicados no artigo "Analysis of plant LTR-retrotransposons at the fine-scale family level reveals individual molecular patterns". Nossos resultados mostraram que as diferentes famílias de LTR-RT em cana-de-açúcar possuem estruturas e regulação distintas. O segundo capítulo desta tese visa responder a perguntas que surgiram durante a primeira metade deste trabalho, mas ao invés de focar no genoma de uma planta optamos por trabalhar com linhagem $\mathrm{Del}$ de LTR-RT em dez genomas de angiospermas sequenciados. Os resultados desta parte do trabalho foram submetidos para publicação no artigo intitulado "Virus-like attachment sites and plastic CpG islands: landmarks of diversity in plant Del retrotransposons". Os resultados mostraram que a LTR é uma região dinâmica e importante para a evolução dos LTR-RTs. Nós especulamos que mudanças nas LTR atuem como gatilhos para a diversificação dos LTR-RTs.

Palavras-chave: Retrotransposon. Linhagem evolutiva. Sítio Att. Ilha CpG. LTR. Plantas. Genoma. Cana-de-açúcar. 


\begin{abstract}
CRUZ, G. M. Q. Unraveling the interactions between retrotransposons and plant genomes, with emphasis on sugarcane. 2014. 94 p. Ph. D. thesis (Biotechnology) - Instituto de Ciências Biomédicas, Universidade de São Paulo, São Paulo, 2014.

This doctoral thesis is structured in two chapters. In the first chapter we explore the LTRretrotransposons (LTR-RT) in sugarcane, these results were published in an article entitled "Analysis of plant LTR-retrotransposons at the fine-scale family level reveals individual molecular patterns". In this paper we show that different sugarcane LTR-RT families have distinct structure and are differentially regulated. In the second chapter we try to find answers to questions that came up in the first half of this work, but instead of focusing in one plant genome we chose to work with the Del lineage of LTR-RT in tem angiosperm sequenced genomes. These results are submitted to publication as an article entitled "Virus-like attachment sites and plastic $C p G$ islands: landmarks of diversity in plant Del retrotransposons". Our results indicate that the LTR region is dynamic and important in the evolution of LTR-retrotransposons, we speculate that it is a trigger for retrotransposon diversification.
\end{abstract}

Keywords: Retrotransposon. Evolutionary lineage. Attachment site. CpG Island. LongTerminal Repeat. Plants. Genome. Sugarcane. 


\section{SUMÁRIO}

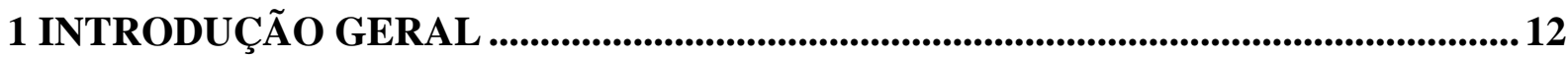

1.1 O que são elementos ............................................................................................................................. 12

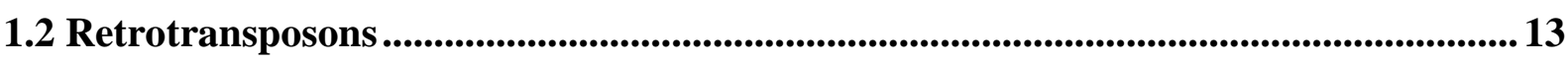

1.3 Retrotransposons com LTR em plantas ..................................................................... 16

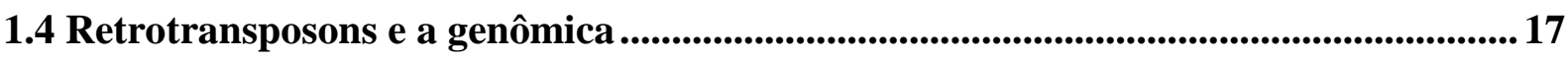

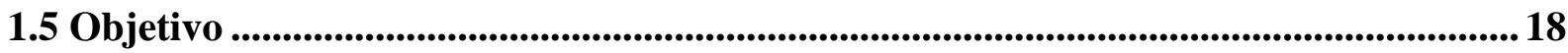

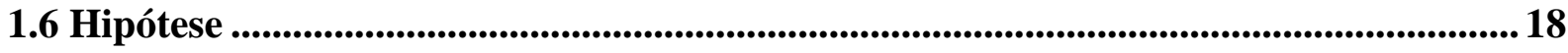

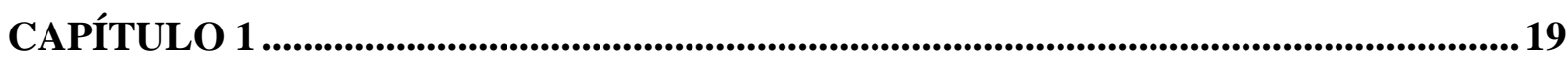

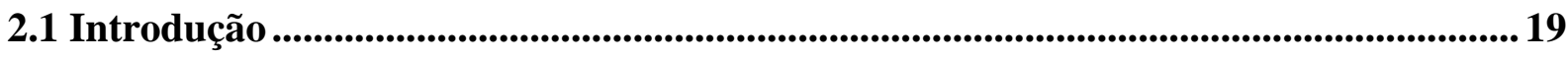

2.1.1 Cana-de-açúcar, aspectos botânicos ...................................................................... 19

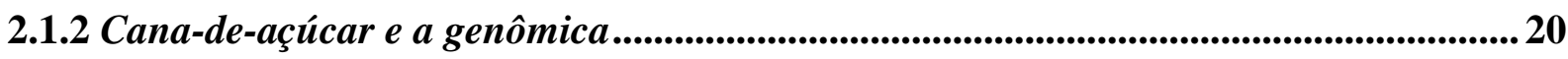

2.2 Materiais e métodos................................................................................................................ 21

2.2.1 Encontrando LTR-RTs em cana-de-açúcar ........................................................................ 21

2.2.2 Estrutura e Classificação ............................................................................................................ 22

2.2.3 Mapeando pequenos RNAs nos elementos encontrados ................................................ 23

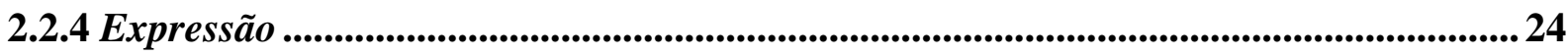

2.2.5 Localização tecidual da expressão do elemento "in situ”........................................... 24

2.2.6 Networks metilação ............................................................................................................... 25

2.2.7 RMs Maximus .................................................................................................................................. 26

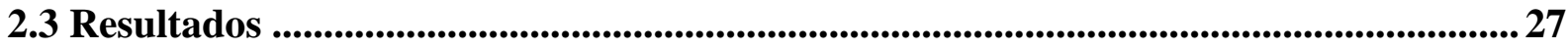

2.3.1 Estrutura e Classificação ..................................................................................................... 27

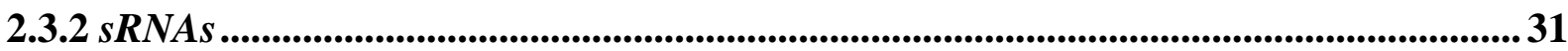

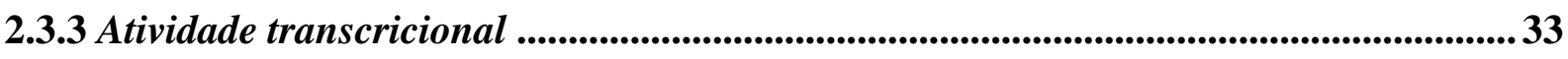

2.3.4 In situ ........................................................................................................................................................... 34

2.3.5 Networks e padrões de metilação ...........................................................................................36

2.3.6 RMs Maximus .......................................................................................................................................... 41

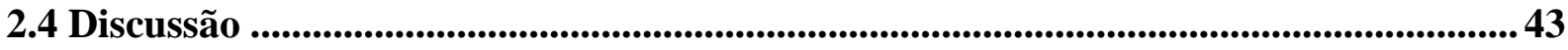

2.4.1 LTR-RTs possuem características estruturais diversas e pertencem a linhagens evolutivas compartilhadas entre monocotiledôneas $e$ eudicotiledôneas................................ 44

2.4.2 Atividade transcricional de LTR-RTs e pequenos RNAs associados ........................... 45

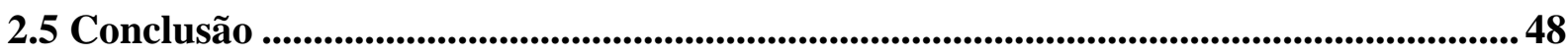

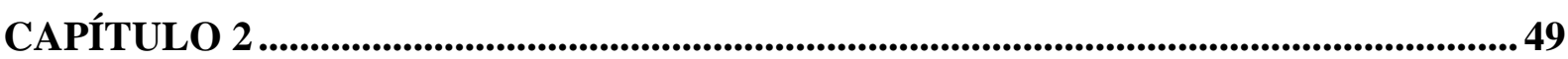


3.1 Introdução

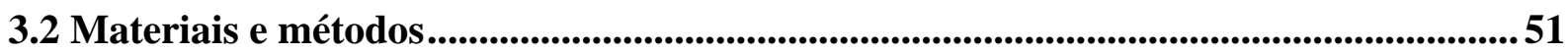

3.2.1 Extração e classificação de elementos completos da linhagem Del .............................51

3.2.2 Análise filogenética .................................................................................................................................5 52

3.2.3 Identificando sítios att nas LTRs ................................................................................................ 52

3.2.4 Explorando características das LTRs ....................................................................53

3.2.5 Distribuição de elementos Del nos cromossomos de milho e sorgo.............................. 54

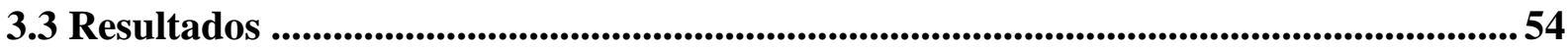

3.3.1 Encontrando elementos Del em dez genomas vegetais .................................................... 54

3.3.2 Análise filogenética da linhagem Del em plantas .....................................................55

3.3.3 Descobrindo os sítios att em LTR-RTs da linhagem Del presente nos 10 genomas.... 58

3.3.4 Explorando as LTRs ......................................................................................................60

3.3.5 Distribuição de elementos da linhagem Del por cromossomo de sorgo e milho........... 62

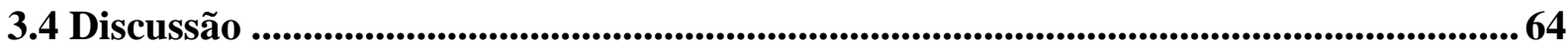

3.4.1 Sítios att identificados e conservados para todas as cópias completas de Del............. 65

3.4.2 A LTR é a estrutura com maior plasticidade em elementos da linhagem Del .............. 66

3.4.3 A presença de ilhas CpG nas LTRs de elementos da linhagem Del .............................. 66

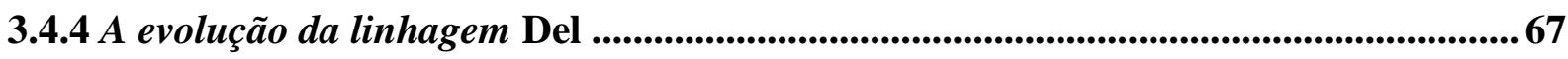

3.4.5 Distribuição de elementos da linhagem Del entre cromossomos de milho e sorgo ..... 68

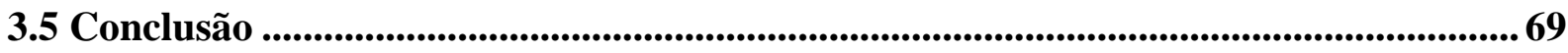

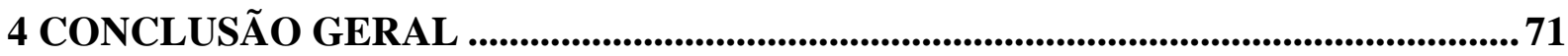

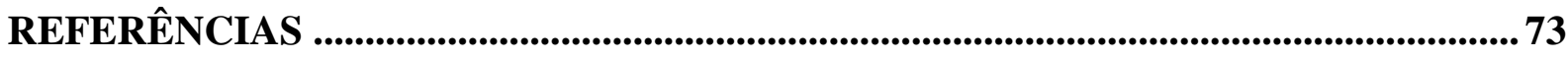

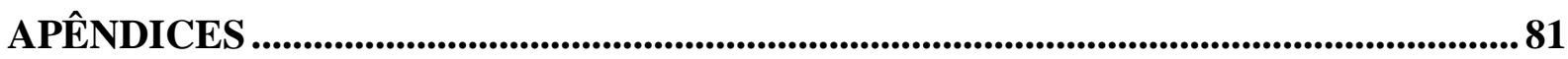

APÊNDICE A - Informações sobre os LTR-RT encontrados em cana-de-açúcar........... 81

APÊNDICE B - Filogenia das superfamílias Gypsy e Copia pela metodologia Maximum

Likelihood. .84

APÊNDICE D - Contagem de 20-22nt e 23-25nt sRNA para cada família de LTR-RT. 90 APÊNDICE E - Famílias a que pertencem os cDNAs previamente estudados de LTRRTs de cana-de-açúcar. .................................................................................................91

APÊNDICE F - Número total de elementos Del identificados em cada genoma e o número desses elementos que foram utilizados em análises envolvendo as LTRs. ..........92 APÊNDICE G - Fig. S2. Conservação dos sítios U5 att do tipo A e B.............................92 APÊNDICE H - Lista de artigos publicados ou em preparação. .......................................... 93 


\section{INTRODUÇÃO GERAL}

\subsection{0 que são elementos}

Elementos de transposição, TE (do inglês, Transposable Elements), são fragmentos de DNA que podem mudar de posição cromossômica e se inserir em novos sítios genômicos e frequentemente podem duplicar suas cópias durante este processo (FESCHOTTE et al., 2002). Eles foram caracterizados inicialmente em plantas de milho por Bárbara McClintock na década de 1940, como agentes responsáveis pela presença de setores de coloração alterada nos grãos. No entanto, somente a partir da descoberta de elementos de transposição em bactérias, fungos e animais-modelo que aspectos moleculares envolvidos na transposição passaram a ser melhor estudados, entre as décadas de 1960 e 1980. Esses elementos estão presentes em grande número de cópias e são capazes de se amplificar e inserir aleatoriamente em diferentes posições no genoma hospedeiro, e podem representar de 50\% a 90\% do genoma de certas espécies vegetais (FLAVELL et al., 1994; SANMIGUEL et al., 1996).

Classicamente, os elementos de transposição são classificados em duas classes, de acordo com algumas características estruturais básicas e ocorrência (ou não) de intermediários de transposição. Os elementos que necessitam de um intermediário de RNA para transposição, são considerados elementos de Classe I ou retrotransposons; os que não dependem de um RNA intermediário para sua replicação são denominados transposons "clássicos” de DNA - de classe II. Elementos de classe II (íntegros ou defectivos) podem também sair do local de inserção e por consequência em algumas situações ocorre a reversão do fenótipo. Já nos fenótipos que sofreram mutação por ação de um retrotransposon, a "reversão" de fenótipos é rara e geralmente dependente de eventos de recombinação (KUMAR; BENNETZEN, 1999).

O sequenciamento em larga escala de genomas, iniciado a partir de meados dos anos 90, resultou em grande volume de dados a respeito de elementos de transposição em diversos organismos, e permitiu a descoberta de novas categorias de elementos que não estão perfeitamente encaixados na divisão acima descrita. 


\subsection{Retrotransposons}

Considerando retrotransposons aqueles elementos que dependem de molde mRNA podemos subdividi-los pela presença ou não de repetições longas terminais (Long Terminal Repeats - LTR). Por sua vez, dentro de cada subclasse de retrotransposons há mais uma subdivisão:

a) Retrotransposons sem LTR (ou retroposons): Long Interspersed Nuclear Elements (LINE) e Short Interspersed Nuclear Elements (SINE).

b) Retrotransposons com LTR: Ty1/Copia e Ty3/Gypsy.

Os retrotransposons com LTR, fração majoritária do genoma de plantas superiores (MCCARTHY et al., 2002), têm características estruturais muito semelhantes aos retrovírus, diferenciando-se apenas por não possuírem uma sequência que codifique a proteína env, responsável pela capacidade de infecção dos retrovírus. No seu processo de mobilização, os retrotransposons não sofrem excisão e reinserção em outro ponto do genoma; a mobilização ocorre devido à inserção de uma nova cópia no genoma, reverso transcrita a partir de um mRNA (CASACUBERTA; SANTIAGO, 2003; KUMAR, 1996). Logo, haverá um aumento exponencial do número de cópias do elemento.

Os retrotransposons com LTR são constituídos por domínios funcionais codificados por dois genes: gag e pol. O domínio gag é responsável por uma proteína semelhante ao capsídeo viral, que está envolvida na maturação e "empacotamento" do RNA e proteínas do retrotransposon a ser posteriormente integrado ao genoma. O gene pol (poliproteína) é responsável por codificar a transcriptase reversa, RNAse H, integrase (ENDO) e uma protease (PROT). As duas primeiras enzimas são necessárias para replicação e transposição, e a integrase permite que o retrotransposon já em forma de DNA possa inserir-se em uma nova região cromossômica. A protease é responsável pela maturação dos diferentes domínios citados da poliproteína.

Baseado no grande número de retrotransposons identificados nos últimos anos decorrente do sequenciamento genômico, o Comitê Internacional de Taxonomia de Vírus descrevem com mais detalhes duas classes de retrotransposons com LTR (HAVECKER et al., 2004): Pseudoviridae e Metaviridae. Estas classes podem ser diferenciadas com base na ordem dos domínios protéicos de retrotransposons considerados arquétipos: os elementos Copia e Gypsy de Drosophila, respectivamente relacionados com os elementos Ty1 e Ty3 de levedura (GRIFFITHS et al., 2001). Os elementos Ty3/Gypsy (Metaviridae) têm uma 
organização mais próxima a dos retrovírus e diferenciam-se do grupo Ty1/Copia (Pseudoviridae) por apresentar o domínio da transcriptase reversa anterior ao domínio da integrase. Ambos os grupos de retrotransposons com LTR são amplamente distribuídos no reino vegetal (SUONIEMI et al., 1998; VOYTAS et al., 1992).

Embora os genes gag e pol sejam necessários e suficientes para um evento de transposição, outras organizações genômicas podem ser observadas para retrotransposons com LTR. Existem retrotransposons com quadros abertos de leitura (open reading frames ORF) extras, na mesma posição em que se encontra o gene env nos retrovírus. Em alguns casos, esta ORF de fato apresenta similaridade com genes env de retrovírus. Embora elementos desse tipo pareçam também estar dispersos por todo o reino vegetal (Vicient et al., 2001), existem poucos elementos completamente caracterizados em plantas, como o retrotransposon SIRE-1 de soja (LATEN et al., 1998) e Tat-1, de Arabidopsis thaliana (WRIGHT; VOYTAS, 1998). Há também casos em que a ORF possui função desconhecida, como no retrotransposon Grande1 de milho (MARTINEZ-IZQUIERDO et al., 1997), que possui uma ORF em orientação antisenso em relação à transcrição do retrotransposon.

Estes elementos podem ser encontrados em diversos genomas eucariotos, retrotransposons com LTR não-autônomos, provavelmente mobilizados em trans por elementos funcionais apenas a condição que possuam uma região promotora funcional. Estes contém algumas estruturas básicas como as LTR, o sítio de ligação do iniciador ("Primer Binding Site" - PBS) à 5' e uma região de polipurinas (“Polypurine Tract" - PPT) à 3'; no entanto, perderam sua capacidade codificante. São divididos em duas classes principais: grandes derivados de retrotransposons (Large Retrotransposon Derivatives - LARDS) (KALENDAR et al., 2004) e retrotransposons de repetição terminal em miniatura (terminalrepeat retrotransposons in miniature - TRIM). Os primeiros possuem alguns milhares de base $(\mathrm{kb})$ em extensão: no caso do LARD Dasheng, de arroz, este tamanho varia de 5.5 a $8 \mathrm{~kb}$ e existem evidências que Dasheng é mobilizado pelo retrotransposon RIRE2 (JIANG et al., 2002). Já os TRIM até hoje conhecidos possuem no máximo 540 pares de base (bp), e muitas vezes são encontrados em regiões promotoras e íntrons de genes, o que indica um potencial papel relevante na estruturação dos genomas vegetais (HAVECKER et al., 2004; WITTE et al., 2001). A figura 1.1 esquematiza a organização genômica dos diferentes tipos de retrotransposons com LTR. 


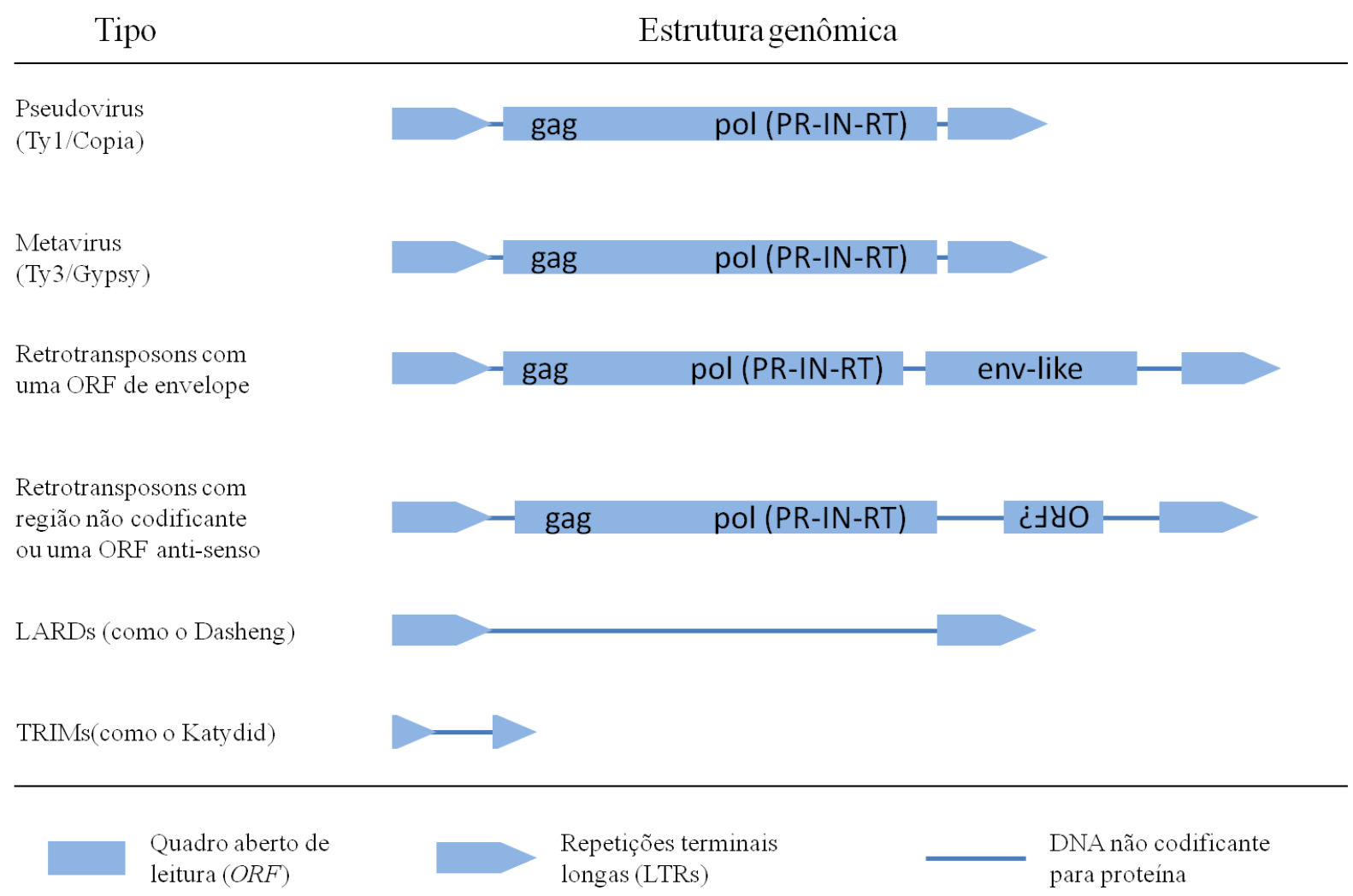

Figura 1.1 - Organização genômica dos principais tipos de retrotransposons com LTR. Adaptado de Havecker et al. (2004).

O papel dos elementos de transposição ainda é bastante controverso, pois eles são vistos basicamente sob dois prismas: de "DNA-parasita", cuja única atividade é sua autorreplicação ou como "reservatórios de variabilidade genética", que funcionariam como ferramenta para a evolução (BENNETZEN, 2000; KUMAR; BENNETZEN, 1999).

As visões não são excludentes, uma vez que existem evidências tanto sobre o papel dos elementos de transposição na evolução de genes e genomas quanto a possíveis impactos negativos oriundos de sua transposição ou atividade transcricional. (PASYUKOVA et al., 2004) observou uma relação negativa entre a capacidade adaptativa de linhagens de Drosophila melanogaster e o acúmulo de elementos de transposição, o que evidencia o reflexo da interrupção de genes e/ou sequências promotoras. No entanto, existem indicações de que elementos de transposição podem estar envolvidos na criação e evolução de genes ( BENNETZEN, 2005; JIANG et al., 2004), bem como já foi observada uma relação entre a função enzimática de telomerases e transcriptases reversas de elementos de transposição (PARDUE; DEBARYSHE, 1999). Estes fatos sugerem a multiplicidade de funções que os elementos de transposição apresentam em todos os seres vivos. 


\subsection{Retrotransposons com LTR em plantas}

Os retrotransposons com LTR em plantas estão dispersos por toda eucromatina, sem uma preferência de localização ao considerarmos o conjunto de elementos do tipo Ty1/Copia e Ty3/Gypsy (KUMAR; BENNETZEN, 1999). A análise de grandes regiões genômicas contíguas em gramíneas de interesse agronômico indica que as regiões intergênicas são ricas em retrotransposons com LTR, inclusive com a presença de elementos interrompidos pela inserção de outro TE (SANMIGUEL et al., 1996). Em cevada, no máximo 5\% do genoma é composto de genes celulares, e estes se encontram "ilhados" em meio a um grande número de cópias de retrotransposons (SCHULMAN; KALENDAR, 2005). Ainda assim, é possível observar que uma família individual de retrotransposons possui número de cópias e distribuição genômica característica (ALIX et al., 2005), inclusive com famílias de retrotransposons Ty3/Gypsy específicas de regiões próximas ao centrômero de cromossomos de gramíneas (PRESTING et al., 1998).

A regulação da expressão e da transposição de um retroelemento é bastante controlada pelo genoma hospedeiro, uma vez que a alta expressão de elementos de transposição tem grande potencial deletério. Embora mecanismos de regulação da expressão de retrotransposons vegetais pela interação com pequenos RNAs (sRNAs) (HAMILTON et al., 2002) já tenha sido descrita, a maior parte dos elementos estudados tem sua expressão controlada pela metilação do promotor do elemento.

Como observado na figura 1.1, a LTR dos retrotransposons tipo Ty1/Copia e Ty3/Gypsy é subdividida em 3 regiões: U3, R e U5. A região U3 da LTR contém a sequência promotora da transcrição do elemento, conforme demonstrado para o retrotransposon Tnt 1 de tabaco (VERNHETTES et al., 1998) e Retrolyc1 (ARAUJO et al., 2001).

Sabe-se que estresses biótico e abiótico são capazes de ativar a expressão de TEs em tecidos vegetais. Tnt1, por exemplo, tem sua transcrição ativada por lesões físicas e pela aplicação de metil jasmonato (MHIRI et al., 1997). Também se observa uma variação do número de cópias do elemento BARE-1 em populações naturais de cevada - plantas que ocupam regiões mais secas e altas possuem mais cópias do elemento, quando comparadas a plantas crescidas em clima mais ameno e baixios (KALENDAR, R., TANSKANEN et al., 2000). Dessa forma, indicam uma relação entre estresses abióticos e a replicação de BARE-1 em cevada. 


\subsection{Retrotransposons e a genômica}

Tradicionalmente, o ponto de partida para a identificação de elementos de transposição em espécies vegetais baseia-se em algumas estratégias como: identificação ao acaso de elementos de transposição que interrompiam algum gene estrutural passível de seleção, como Tnt1 (GRANDBASTIEN et al., 1989), identificação de uma sequência repetitiva majoritária no genoma estudado, como BARE-1 (MANNINEN; SCHULMAN, 1993) e RIRE1 (NOMA et al., 1997), sequências provenientes da amplificação de fragmentos genômicos (MATSUOKA; TSUNEWAKI, 1999) e/ou cDNAs ( GALINDO et al., 2004; HIROCHIKA, 1993) de regiões conservadas da transcriptase reversa de retrotransposons, ou apresentavam homologia nucleotídica com algum TE previamente descrito, caso de Retrolyc1 (COSTA et al., 1999). No entanto, as abordagens genômicas revolucionaram a metodologia de identificação de elementos de transposição, uma vez que o sequenciamento em larga escala de genomas e transcriptomas resultaram na identificação em massa de elementos de transposição em diversas espécies. A partir de sequências genômicas depositadas em bancos de dados, foram identificadas dezenas de famílias de retrotransposons em arroz (MCCARTHY et al., 2002) e Arabidopsis thaliana (ZHANG et al., 2004) e a partir de bancos de ESTs, foram identificados retrotransposons em Schistosoma mansoni (DEMARCO et al., 2004) e trigo (ECHENIQUE et al., 2002).

Com a criação do banco de dados do SUCEST (VETTORE et al., 2001; VINCENTZ et al., 2004), verificou-se in silico a presença de ESTs relacionados a elementos de transposição em cana (ROSSI; VAN SLUYS, 2001). Com um elevado grau de estringência foi possível identificar no banco de dados de quase 250.000 sequências, 276 clones relacionados claramente relacionados a elementos de transposição. Posteriormente, foi confirmada a similaridade de parte deste clones após sequenciamento integral dos cDNAs (ARAUJO, et al., 2005a). Foi elaborada em paralelo uma análise detalhada de duas famílias de transposons hAT e Mutator (DE JESUS et al., 2012; SACCARO et al., 2007).

Portanto, o banco de dados do SUCEST forneceu subsídios importantes para o isolamento e caracterização em larga escala de diversas famílias de elementos de transposição em cana. Algumas dessas famílias puderam ter seus níveis de expressão e atividade caracterizados mais detalhadamente, e demonstraram que alguns desses elementos ativam-se em condições específicas (ARAUJO et al., 2001).

Portanto, ao longo do tempo, novas metodologias passaram a ser utilizadas para a identificação de elementos de transposição, resultando em um volume crescente de 
informações. Assim o uso de diversas cópias de uma mesma família de elementos para a reconstrução de uma sequência consenso in silico. O elemento Tvv1 de uva (PELSY; MERDINOGLU, 2002) e as famílias Saci 1-7 e Perere (DEMARCO et al., 2004, 2005) são exemplos de retrotransposons "reconstruídos" a partir de um conjunto de estratégias in silico e de bancada.

\subsection{Objetivo}

Esta tese tem como objetivo atestar a individualidade dos LTR-RTs. Mesmo classificando-os em linhagens, cada família dentro da mesma linhagem possui particularidades. Dentro dessas famílias encontramos elementos de estrutura semelhante, mas que possuem comportamentos diferentes e podem impactar o genoma de maneiras distintas, dependendo de sua localização, orientação e atividade transcricional.

\subsection{Hipótese}

As linhagens de retrotransposons com LTR presentes em um dado genoma apresentam-se como unidades biológicas funcionais distintas. 


\section{CAPÍTULO 1}

\subsection{Introdução}

\subsubsection{Cana-de-açúcar, aspectos botânicos}

A cana-de-açúcar (Saccharum spp) é uma planta pertencente à família Poaceae, assim como o arroz (Oryza sativa) e juntamente com sorgo e milho (Sorghum bicolor e Zea mays) pertencem à tribo Andropogonae. Segundo (CASTRO; KLUGE, 2001) a cana pertence à sub tribo Saccharine, como Miscanthus sp. e Erianthus sp. É considerada originária do Sudeste Asiático, na grande região das ilhas da Nova Guiné e Indonésia (DANIELS; ROACH, 1987). Inicialmente, cultivava-se principalmente a espécie Saccharum officinarum (L.), mas com o desenvolvimento de programas de melhoramento genético, híbridos interespecíficos resistentes e melhor adaptados às diversas condições ambientais permitiram a expansão da cultura pelo planeta (MATSUOKA; TSUNEWAKI, 1999). Os parentais deste híbrido estão descritos abaixo:

S. officinarum L. $(2 \mathrm{n}=80)$ : esta é uma espécie poliploide, cujo centro de diversidade é a Nova Guiné, seu centro de origem é desconhecido. Admite-se que ela tenha surgido naquela mesma região, a partir de S.spontaneum, Miscanthus e Erianthus arundinaceus, também cruzando com S.robustum. Constitui-se a espécie-base dos programas de melhoramento para a qual se faz cruzamentos recorrentes (introgressão), com o objetivo de preservar características específicas, como colmos suculentos, elevado teor de sacarose, qualidade do caldo e teor de fibra adequado para moagem. São exigentes em clima e solo e muito sensíveis a doenças. Até 1925, no Brasil, principalmente no Estado de São Paulo, eram plantados os cultivares conhecidos como: Riscada, Roxa, Cristalina, Manteiga, Caiana, Preta, entre outras, todas pertencentes a essa espécie.

S. spontaneum L. $(2 \mathrm{n}=40$ - 128): é uma espécie altamente polimórfica, que cresce no trópico e subtrópico, provavelmente, produto da introgressão entre membros do complexo

Saccharum. É a espécie que moderadamente tem dado maior contribuição ao melhoramento genético, com suas características de vigor, perfilhamento e capacidade de rebrota de soqueira, especialmente devido ao vigoroso rizoma e a resistência a estresses, doenças e pragas. São plantas de menor porte, colmos curtos e finos, fibrosos e praticamente sem açúcar. O sistema radicular é bem desenvolvido com grande perfilhamento da touceira, 
repercutindo em adaptação a condições adversas de solo e clima. Sobretudo as cultivares desta espécie se diferenciam de $S$. officinarum pela resistência ao vírus da mosaico. Fazem parte desta espécie os cultivares Kans, da Índia e Glagah, de Java.

\subsubsection{Cana-de-açúcar e a genômica}

A cana-de-açúcar é uma importante cultura tropical produzida para obtenção de açúcar e em alguns países, como o Brasil, também para a produção de álcool e destilados. Cerca de $60 \%$ do açúcar bruto produzido no mundo é proveniente desta planta, que é cultivada em mais de noventa países (GRIVET; ARRUDA, 2002). O etanol ajudou a impulsionar as safras da cana no Brasil nos últimos anos, que segundo a união da indústria da cana-de-açúcar (UNICA) cresceu de 222.429.000 toneladas (1990/1991) para 532.758.000 toneladas (2007/2008). A despeito de sua importância econômica, aspectos genômicos da cana são pouco estudados em comparação a outras plantas de interesse econômico (HOTTA et al., 2010). A falta de abordagens genômicas mais amplas se deve ao fato do genoma desta planta, além de ser híbrido entre espécies, apresentar elevado grau de poliploidia e aneuploidia e contribuição heterogênea entre as espécies envolvidas. Os cultivares modernos apresentam genomas de até $10 \mathrm{~Gb}$, contendo entre 100 a 130 cromossomos nos núcleos de suas células (PIPERIDIS et al., 2010).

Uma abordagem eficiente que permitiu acessar parte do conteúdo gênico foi realizada no programa SUCEST no qual foram sequenciados parcialmente genes expressos em diferentes tecidos desta planta. Os bancos de dados de sequências expressas (ESTs-database) oferecem uma oportunidade para a construção de mapas funcionais, os quais servem de base para a estratégia de genes candidatos. O projeto de sequenciamento de ESTs (SUCEST) do programa Genoma da FAPESP permitiu o agrupamento em cerca de 40 mil SAS que representam os genes de cana-de-açúcar.

Originalmente, o SUCEST gerou 238.000 sequências parciais de cDNAs denominadas de ESTs, que foram agrupadas em quase 43.000 SAS (Sugarcane Assembled Sequences). O projeto SUCAST (Sugarcane Signal Transduction) (PAPINI-TERZI et al., 2005; SOUZA et al., 2001) utilizou estratégias computacionais de busca por padrões para selecionar neste banco sequências com similaridade a genes previamente estudados objetivando identificar proteínas-G, receptores, fatores de transcrição, entre outros. Além disso, SAS que estivessem envolvidos em processos ativados por estresse, invasão de patógenos, ou exercessem papéis importantes no crescimento ou desenvolvimento da planta, foram catalogados. 
Teve início em 2009 o sequenciamento do genoma da cana-de-açúcar, financiado pela FAPESP através do programa de bioenergia (BIOEN). Uma das estratégias adotada foi a de sequenciar BACs, de $100 \mathrm{~Kb}$ de tamanho médio, em pirossequenciadores (454 Roche). Grande parte destes BACs foram montados e sequenciados em nosso laboratório e se mostraram uma vasta fonte de elementos transponíveis.

Existem na literatura alguns trabalhos que descrevem elementos de transposição em cana-de-açúcar (GARSMEUR et al., 2010; JANNOO et al., 2007; ROSSI; VAN SLUYS, 2001; WANG et al., 2010; ), mas nosso grupo publicou o primeiro estudo detalhado de LTRRTs deste genoma (DOMINGUES et al., 2012). Identificar e classificar cópias completas de TEs é uma tarefa cada vez mais importante, uma vez que conhecer estes elementos auxilia a montagem de genomas, torna mais preciso o processo de anotação gênica e facilita estudos funcionais de genes do genoma em questão (BENNETZEN et al., 2004).

Em nosso trabalho, LTR-RTs do genoma da cana-de-açúcar foram caracterizados utilizando sequências públicas deste genoma assim como sequências de BACs do projeto BIOEN-FAPESP. Nós examinamos a estrutura, diversidade evolutiva e atividade transcricional destes elementos. Este estudo revelou que dentro de linhagens evolutivas bem definidas, LTR-RTs da mesma família possuem estrutura semelhante, mas comumente apresentam atividade transcricional e assinaturas regulatórias distintas. Estes resultados compõem um manuscrito aceito para publicação intitulado "Analysis of plant LTRretrotransposons at the fine-scale family level reveals individual molecular patterns".

\subsection{Materiais e métodos}

\subsubsection{Encontrando LTR-RTs em cana-de-açúcar}

Todos os BACs utilizados no presente estudo vieram da mesma biblioteca, preparada com DNA do cultivar R570 (TOMKINS et al., 1999). Alguns BACs foram sequenciados pelo projeto BIOEN enquanto outros estavam disponíveis no National Center for Biotechnology Information (NCBI; http://www.ncbi.nlm.nih.gov/) em 01/02/2011. Utilizamos o programa LTR_STRUC (MCCARTHY; MCDONALD, 2003) para buscar por LTR-RTs, o programa foi rodado com os parâmetros definidos pelo programa, na opção mais rigorosas (1). Sessenta elementos foram encontrados e atribuídos provisoriamente às superfamílias Gypsy ou Copia. Para tanto, as regiões codificantes destes elementos foram submetidas a uma busca em banco de dados por alinhamento local com a ferramenta BLASTx no Gypsy Database (GyDB) 
(LLORENS et al., 2011). Para determinar se os elementos eram completos, submetemos cada sequência a uma análise por alinhamento par a par BLAST2seq (SAYERS et al., 2011) no NCBI contra ela mesma. Deste modo, foi possível determinar as marcas de duplicação do sítio de inserção (TSDs).

\subsubsection{Estrutura e Classificação}

Os LTR-RTs encontrados em cana-de-açúcar, pelo método descrito acima, foram atribuídos a linhagens previamente descritas (WICKER; KELLER, 2007; DU et al., 2010; LLORENS et al., 2011) através de uma análise filogenética. Utilizamos o domínio codificante da transcriptase reversa encontrado em todos os LTR-RTs para a realização do estudo evolutivo com base em literatura prévia (LLORENS et al., 2011; WICKER; KELLER, $2007 ;)$.

Fizemos uma árvore filogenética para a superfamília copia e outra para a superfamília Gypsy. Utilizamos sequências do Gypsy database (GyDB) (LLORENS et al., 2011) para ambas as árvores, removendo apenas aquelas que não pertenciam a elementos de plantas.As transcriptases reversas de outros elementos usados para montar a árvore da superfamília Gypsy foram retiradas do trabalho de Du et al. de 2010, enquanto os elementos do trabalho de Wicker e Keller (2007) complementaram a análise da superfamília Copia. Todas as sequencias $(\sim 700 \mathrm{pb})$ foram renomeadas para melhor representar o nome das linhagens e foram então alinhadas no programa MUSCLE com parâmetros padrões (EDGAR, 2004), os alinhamentos foram corrigidos manualmente. O modelo ótimo de substituição de aminoácido foi estimado utilizando o programa MEGA5 (TAMURA et al., 2011a) com parâmetros padrões. Foram geradas árvores filogenéticas utilizando os métodos de Neighbor-Joining e Maximum-Likelihood com o programa MEGA5 (TAMURA et al., 2011a). Para tanto, foram utilizados os modelos de substituição sugeridos pelo programa e um bootstrap de 500 réplicas.

Dentro de cada linhagem evolutiva, os elementos de cana-de-açúcar foram associados a famílias se tivessem ao menos $80 \%$ de sua LTR alinhada a de outro elemento, com ao menos $80 \%$ de identidade (WICKER et al., 2007). Apesar de alguns estudos prévios darem nomes a LTR-RTs de cana-de-açúcar (ARAUJO et al., 2005a; GARSMEUR et al., 2010), nós optamos por padronizar a nomenclatura de todos os elementos de cana-de-açúcar adotando a classificação universal de TEs proposta por Wicker e colaboradores (2007). As sequências foram nomeadas como 'RLC' (se fossem Copia) ou 'RLG' (se fossem Gypsy), seguido por um 
'sc' de 'sugarcane', seguido pelo nome da linhagem (ex: 'Ale'), e então pelo número da família e pelo número da sequência dentro daquela família. A partir de então, cada sequência dentro de uma família foi nomeada em ordem numérica, por exemplo: 'RLC_scAle_1.1' é a primeira sequência descoberta dentro da família 1 da linhagem Ale, pertencendo a superfamília Copia.

Domínios codificantes foram encontrados através de busca no banco pFAM (PUNTA et al., 2012) ou através de alinhamentos dos domínios depositados no GyDb (LLORENS et al., 2011)e as sequências identificadas por nós utilizando o programa MUSCLE (EDGAR, 2004). Sequências completas foram alinhadas e analisadas através da ferramenta BioEdit (HALL, 1999), utilizando a ferramenta rápida de tradução. Deste modo foi possível alinhar as regiões codificantes, as LTRS, TSDs e as regiões entre as LTRs e a região codificante. Para encontrar as LTRs cada sequência foi submetida a um BLAST2seq (SAYERS et al., 2011) contra ela mesma no NCBI. A extremidade de cada LTR, assim como as duplicações vicinais foram identificados através de alinhamento e inspeção manual no BioEdit (HALL, 1999). Colocamos as coordenadas do começo de cada estrutura em uma planilha do Excel. Esta planilha foi inserida no programa domain draw (FINK; HAMILTON, 2007) para criar uma representação gráfica da estrutura de cada LTR-RT de cana-de-açúcar encontrado.

Caraterísticas gerais de cada sequência estão contidas na planilha do APÊNDICE A, sendo elas: tamanho do elemento (em pares de base; bp), tamanho da LTR (em pares de base; bp), Target Side Duplications (TSD) e os números de acesso do GenBank.

\subsubsection{Mapeando pequenos RNAs nos elementos encontrados}

Para avaliar a presença e a distribuição de pequenos RNAs, sequências oriundas de uma biblioteca de pequenos RNAs de tecido foliar de plantas de um mês de idade do cultivar SP80-32-80, crescidas em estufas foram alinhadas sobre as unidades de RT-LTRs isoladas acima. Esta biblioteca foi preparada por nosso colaborador Fábio Tebaldi Nogueira e sua equipe (ORTIZ-MOREA et al., 2013). Esses colaboradores sequenciaram em Illumina (GAIIx) um total de 4,388,665 sequências de tamanho variado entre 20 a 25 nucleotídeos.

Em uma segunda colaboração, o pesquisador Renato Vicentini utilizou a ferramenta MAQ (LI et al., 2008) para mapear estes pequenos RNAs ao longo das sequências de LTRRT encontradas em cana-de-açúcar. Aproximadamente três por cento das sequências desta biblioteca (131,641 pequenos RNAs) possuem similaridade (e no máximo dois mismatches) com os elementos descritos neste estudo. Estas sequências foram depositadas no banco de 
dados NCBI Gene Expression Omnibus (http://www.ncbi.nlm.nih.gov/geo) e receberam o número de acesso GSE35143.

\subsubsection{Expressão}

Todas as cópias completas de LTR-RTs encontradas foram submetidas a um BLASTn contra o banco de transcritos de cana-de-açúcar do cultivar SP80-3280. Essas sequências foram obtidas através do NCBI. Um total de 155,354 transcritos de cana-de-açúcar foram utilizados nessa análise, todos oriundos do projeto SUCEST (VETTORE et al., 2001).

Transcritos similares às unidades definidas como LTR-RTs foram assinalados a famílias de acordo com o critério descrito por Wicker e colaboradores (2007): mínimo de $80 \%$ de cobertura e $80 \%$ de identidade.

O número de sequências encontradas foi normalizado por biblioteca, dividindo o número de sequências encontradas pelo número de sequência de cada biblioteca. Este número, já normalizado, foi agrupado por tecido. Cada soma de números normalizados, representando um tecido, foi então multiplicada por 100.000 .

\subsubsection{Localização tecidual da expressão do elemento "in situ”}

Para o preparo de sondas, escolhemos utilizar os iniciadores das transcriptases reversas da família Ale1. Após a reação de amplificação e posterior clonagem em plasmídeo TOPO®

Dual Promoter (Life Technologies - Carlsbad, Califórnia, Estados Unidos) realizamos a digestão do DNA com a enzima NotI e seguimos o protocolo de marcação do DIG RNA Labeling Kit (SP6/T7) (Roche Cat. No 11175025910) com a enzima SP6, para gerar a sonda anti-senso de scAle1 marcada.

As pontas das raízes (aprox. $10 \mathrm{~cm}$ ) de cana-de-açúcar (var. R570) crescidas em vasos foram cortadas com bisturi imersas a vácuo em uma solução de 4\% paraformaldeído com duas pastilhas de $\mathrm{NaOH}$ em água DEPEC por uma noite (ON do inglês Over Night). No dia seguinte estas raízes foram submetidas a uma série de 30\% etanol - 5 horas, 50\% etanol - 5 horas e $70 \%$ etanol - ON. No dia seguinte continuamos a desidratação com imersões das raízes em $80 \%$ etanol $\left(4{ }^{\circ} \mathrm{C}\right)-5$ horas, $90 \%$ etanol $\left(4{ }^{\circ} \mathrm{C}\right)-5$ horas e $100 \%$ etanol $\left(-20{ }^{\circ} \mathrm{C}\right)$ ON. Posteriormente, secções de $\sim 1 \mathrm{~cm}$ foram emblocadas em Paraplast ${ }^{\circledR}$ (Sigma-Aldrich Saint Louis, Missouri, estados unidos) (mistura de parafina com polímeros plásticos) e secou em geladeira ON. O material emblocado foi cortado em micrótomo e fixado em lâminas 
preparadas com organossilana (para auxiliar a fixação). As lâminas foram desparafinadas através de uma série de lavagens de $15^{\prime}$ 100\% xylol, 15' 100\% xylol, 15' 3:1 xylol:etanol, 15' 1:1 xylol:etanol, 15 ' 1:3 xylol:etanol, $15,100 \%$ etanol e $15,100 \%$ etanol.

Para a hibridização das sondas uma cuba de plástico e placas de vidro para apoiar as lâminas foram limpas com álcool 70\%. O fundo das cubas foi forrado com papel umedecido com água destilada. As lâminas foram colocadas sobre as placas de vidro e foi adicionado homogeneamente $300 \mathrm{uL}$ da solução de hibridização $(300-600 \mathrm{ng} / \mathrm{ml}$ da sonda $36 \mathrm{ul}+132 \mathrm{ul}$ Tris HCL 1M pH:7,5-8 + $720 \mathrm{ul} \mathrm{NaCl} 5 \mathrm{M}+3 \mathrm{ml}$ Formamida deionizada + 120 ul EDTA 0,5 M + 144 ul Denharts $+1,44 \mathrm{ml}$ de Dextran Sulfato 50\%). Uma película de parafilm foi colocada sobre as lâminas, que foram incubadas em câmaras úmidas a $42^{\circ} \mathrm{C}, \mathrm{ON}$. Foram realizadas lavagens das lâminas em cubetas de vidro autoclavada depois da retirada rápida do parafilm: SSC $4 \mathrm{x}-30^{\prime}$ a $42^{\circ} \mathrm{C}(2 \mathrm{x})$, SSC $2 \mathrm{x}-30^{\prime}$ a $42^{\circ} \mathrm{C}(2 \mathrm{x})$. As lâminas foram lavadas por 1 min com água autoclavada em temperatura ambiente.

A imuno-detecção ocorreu através da incubação das lâminas por uma hora em camara úmida à temperatura ambiente com a solução de imuno-detecção: Anticorpo Anti-DIG:AP, 1:1000 em DB2 (300ul por lâmina). Para a revelação as lâminas foram incubadas O.N. com 300 ul por lamina de uma solução de revelação (4,5 ul NBT + 3.5 ul BCIP em DB3). Cobrir com a lamínula e deixar numa gaveta na escuridão. As lâminas foram montadas e o resultado foi observado em microscópio.

\subsubsection{Networks metilação}

DNA estoque do laboratório de duas variedades parentais Mandalay (S. spontaneum) e Badila (S. officinarum) e dois híbridos comerciais R570 e SP80-3280, previamente extraídos de folhas, foram utilizados nesta análise. Uma parte do DNA total da variedade R570 foi digerida com a enzima McrCB. Essa enzima é conhecida por digerir apenas sítios metilados permitindo contrastar estas regiões com as não metiladas presentes em um dado genoma. Resultando, portanto em cinco amostras de DNA: Mandalay, Badila, SP80-3280, R570 e R570 digerido com a enzima McrBC, que permite identificar a fração não metilada desses genomas, como veremos adiante.

A seguir foi realizada a amplificação de fragmentos da transcriptase reversa de elementos das linhagens Ale, Del e Maximus para cada material. Para tanto, foram utilizados os iniciadores, desenhados sobre a transcriptase reversa de cada elemento, em uma amplificação de 30 ciclos. 
Como apenas fragmentos não digeridos são amplificados, o material que foi digerido com a enzima McrBC é enriquecido em trechos de DNA não metilados, e a partir deste momento será chamado de R570 não metilado (ou R570NM).

Os fragmentos amplificados foram clonados em plasmídeos pGEM®-T Easy (Promega - Madison, Wisconsin, Estados Unidos). Os plasmídeos foram inseridos em bactérias E.coli DH10b através do protocolo de transformação por eletroporação (SAMBROOK et al., 1989). Os clones foram crescidos em meio de cultura LB Agar e realizamos a extração de DNA, também chamada de minipreparação plasmidial (SAMBROOK et al., 1989). O DNA extraído continha os fragmentos de interesse e foram sequenciados em sequenciador capilar automático do modelo 3130XL da empresa Applied Biosystems.

As sequências de todas as variedades foram alinhadas através da ferramenta online MUSCLE (EDGAR, 2004), com parâmetros pré-definidos. O alinhamento foi visualizado no programa JalView (WATERHOUSE et al., 2009), onde a orientação das sequências foi definida. Para deixar todas as sequências na mesma orientação utilizamos a ferramenta online Reverse Complement (STOTHARD, 2000). Em seguida, realizamos um novo alinhamento através do MUSCLE. O resultado deste alinhamento foi utilizado para a geração de diagramas de network, como descrito abaixo.

Para construir os diagramas de network, os alinhamentos foram convertidos em arquivo de formato Roehl (rdf), com deleção de sítios invariáveis e ignorando sítios com gaps, pelo programa DnaSP versão 5 (ROZAS; ROZAS, 1995). Esse arquivo foi utilizado para a geração dos diagramas de network pelo programa Network da Fluxus (BANDELT et al., 1999), através do método de Median-joining e com os parâmetros pré-definidos pelo programa.

\subsubsection{RMs Maximus}

Observamos motivos repetitivos (RM) nas LTRs dos retrotransposons da família scMaximus1. Utilizamos a ferramenta mFold (ZUKER, 2003) para analisar possíveis dobramentos de moléculas simples fita. Para tanto, as sequências de LTRs contendo os RMs foram submetidas a uma análise com os parâmetros padrão da ferramenta. 


\subsection{Resultados}

\subsubsection{Estrutura e Classificação}

A nomenclatura das linhagens evolutivas de LTR-RT não é utilizada de maneira consistente na literatura, com ao menos duas fontes dando nomes diferentes as mesmas linhagens (DU et al., 2010; LLORENS et al., 2011; WICKER; KELLER, 2007). Nós optamos por incluir sequências de ambas as fontes, possibilitando a comparação direta de nossos resultados com qualquer dado publicado que siga uma das duas nomenclaturas. Podemos inferir pela nossa árvore filogenética que as seguintes linhagens são equivalentes: Del é Tekay; Maximus é Sire; Ale é Retrofit e Ivana é Oryco. (Figuras 2.1 e 2.2; APÊNDICE B). As linhagens mais difíceis de traçar o paralelo foram: TAR, Angela, Tork e Bianca. Isto porque Bianca não está inclusa no GyDb (LLORENS et al., 2011); Tork parece ser a combinação das linhagens Angela e TAR (Figura 2.2; APÊNDICE B). 


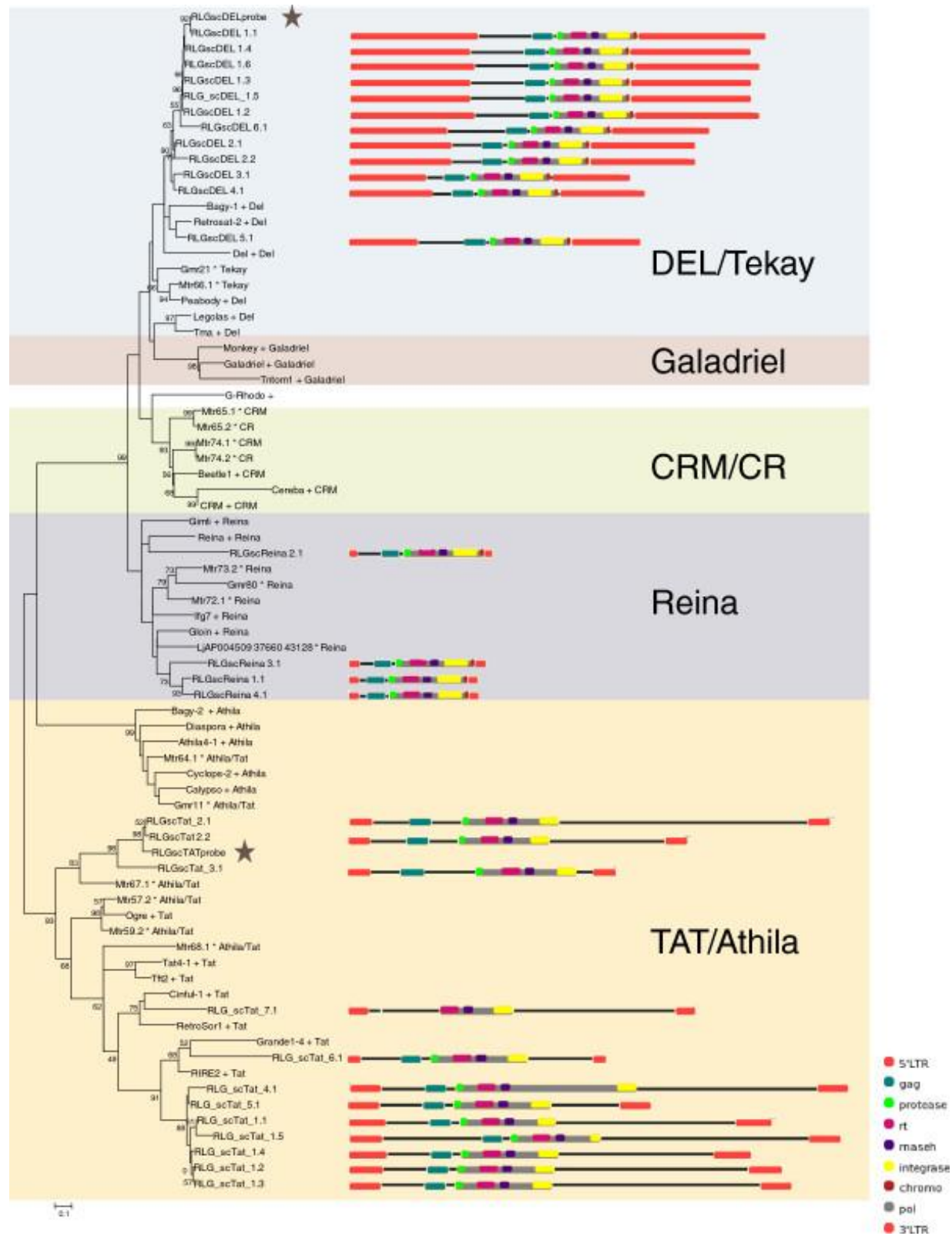

Figura 2.1 - Filogenia da superfamília Gypsy. A árvore filogenética da superfamília Gypsy foi construída através da metodologia de Neighbour-joining (NJ) e tem como base o alinhamento da sequência nucleotídica contendo o domínio proteico da transcriptase reversa $(\sim 700 \mathrm{pb})$ de elementos dessa superfamília. À direita da árvore podemos observar representações esquemáticas de elementos extraídos do genoma da cana-deaçúcar. As sequência retiradas do Gypsy database (LLORENS et al., 2011) estão marcadas com um sinal de mais (+) e aquelas encontradas por Du et al. (2010) estão marcadas com um asterisco (*). A robustez de cada nó foi estimada com um bootstrap de 500 réplicas. Bootstraps com valores inferiores a $50 \%$ não estão apresentados na árvore. As linhagens estão delimitadas por blocos coloridos. As representações esquemáticas foram criadas com o auxílio da ferramenta domain draw (FINK; HAMILTON, 2007). A legenda com as cores dos domínios codificantes apresentados nos esquemas está disponível no canto inferior direito da figura. As abreviações e cores estão representadas assim: LTR = long terminal repeat (vermelho); gag = Gag (verde escuro); protease = Protease (verde claro); $\mathrm{rt}=$ Transcriptase reversa (rosa); rnaseh = Ribonuclease $\mathrm{H}$ (roxo); integrase = Integrase (amarelo); chromo = Chromodomínio $($ marrom); pol = Polyprotein (cinza). 


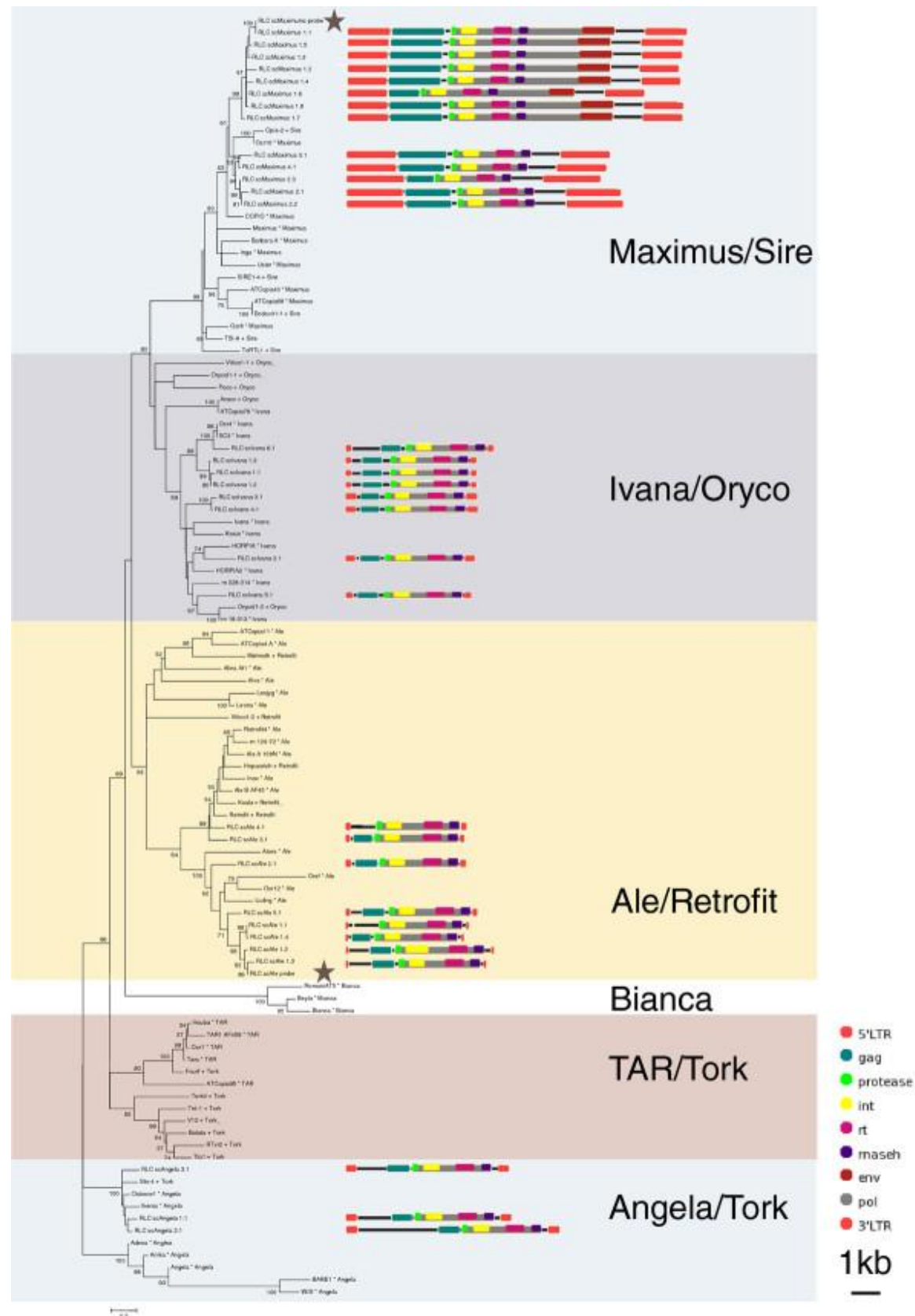

Figura 2.2 - Filogenia da superfamília Copia. A árvore filogenética da superfamília Copia foi construída através da metodologia de Neighbour-joining (NJ) e tem como base um alinhamento da sequência nucleotídica contendo o domínio proteico $(\sim 700 \mathrm{pb})$ de elementos dessa superfamília. À direita da árvore podemos observar representações esquemáticas de elementos extraídos do genoma da cana-de-açúcar. As sequência retiradas do Gypsy database (LLORENS et al., 2011) estão marcadas com um sinal de mais (+) e aquelas encontradas por Du et al.(2010) estão marcadas com um asterisco (*). A robustez de cada nó foi estimada com um bootstrap de 500 réplicas. Bootstraps com valores inferiores a $50 \%$ não estão apresentados na árvore. As linhagens estão indicadas por blocos coloridos. As representações esquemáticas foram criadas com o auxílio da ferramenta domain draw (FINK; HAMILTON, 2007). A legenda com as cores dos domínios codificantes apresentados nos esquemas está disponível no canto inferior direito da figura. As abreviações e cores estão representadas assim: LTR = long terminal repeat (vermelho); gag $=$ Gag (verde escuro); protease = Protease (verde claro); $\mathrm{rt}=$ Transcriptase reversa(rosa); rnaseh = Ribonuclease H (roxo); integrase = Integrase (amarelo); env = Envelope $($ marrom $) ;$ pol = Polyprotein $($ cinza $)$. 
Das sessenta cópias completas encontradas em BACs de cana-de-açúcar, trinta e duas são da superfamília Copia e vinte e oito da superfamília Gypsy (Tabela 2.1; Figuras 2.1 e 2.2). Nós encontramos, no genoma da cana-de-açúcar, elementos pertencentes a quatro das seis grandes linhagens evolutivas da superfamília Copia descritas por Wicker e Keller (WICKER; KELLER, 2007) (Figura2.2; APÊNDICE B), e três das seis linhagens de Gypsy descritas por Du e colaboradores (2010) e por Llorens e colaboradores (2011) (Figura 2.1; APÊNDICE B). Em termos de número absoluto de sequências, as linhagens mais representadas foram: Maximus, da superfamília Copia, com 13 sequências; as linhagens Del e Tat apresentaram 12 cópias cada e representam as linhagens mais numerosas da superfamília Gypsy. Deve-se lembrar que se trata de um conjunto restrito de BACs de R570. Classificamos os elementos em 35 famílias, de acordo com a identidade de suas LTRs (Tabela 2.1) (WICKER et al., 2007). Para facilitar a leitura no texto nós nos referimos a estas famílias simplesmente como Ale1, ao invés de utilizar o seu nome completo RLC_scAle_1.

Tabela 2.1 - Características gerais de linhagens de LTR-RT de cana-de-açúcar

\begin{tabular}{lcccc}
\hline Superfamília/Linhagem & Tamanho $(\mathrm{kb})$ & LTR $(\mathrm{pb})$ & Famílias & Sequências \\
\hline Copia & & & & \\
Ale & $4,7-5,9$ & $116-238$ & 5 & 8 \\
Angela & $6,5-8,5$ & $434-461$ & 3 & 3 \\
Ivana & $5-5,9$ & $238-454$ & 6 & 8 \\
Maximus & $10,2-13,6$ & $1607-2004$ & 4 & 13 \\
Total Copia & & & 18 & 32 \\
\hline Gypsy & & & 6 & 12 \\
DEL & $11,3-16,7$ & $2762-5139$ & 6 & 4 \\
Reina & $5,1-5,7$ & $315-416$ & 4 & 12 \\
TAT & $9,2-17,7$ & $458-1345$ & 7 & 28 \\
Total Gypsy & & 17 & 60 \\
\hline
\end{tabular}

Todos os domínios codificantes (gag, protease, reverso transcriptase, integrase e RNAseH) foram identificados em todas as sequência de cana-de-açúcar. Cabe ressaltar uma única exceção a ausência do domínio gag de RLG_scTat_7.1 (Figura 2.1). Além disso, identificamos um suposto domínio proteico de um envelope nos elementos da família 
Maximus1 (Figura 2.2) e um cromodomínio em todos os elementos das linhagens Del e Reina (Figura 2.1) (LLORENS et al., 2011).

Um padrão foi encontrado quando observamos o tamanho dos elementos das duas superfamílias. Em ambas as superfamílias encontramos uma linhagem em cada com LTRs longas (Maximus e Del, 10,2-16,7 kb), e pelo menos uma linhagem cujo tamanho era pequeno quando comparada às demais (Ivana, Ale e Reina, entre 4,7 e 5,9 kb) (Figuras 2.1 e 2.2). Dentro da superfamília Copia a linhagem Angela apresentou tamanho intermediário (6.5-8.5 $\mathrm{kb})$, enquanto na superfamília Gypsy a linhagem Tat $(9.2-17.7 \mathrm{~kb})$ mostrou ter um tamanho mais comparável a linhagem Del (11.3-16.7 kb) (Figuras 2.1 e 2.2). As diferenças de tamanho dos elementos exploradas aqui derivam majoritariamente de diferenças no tamanho das LTRs (Figuras 2.1 e 2.2), com a exceção da linhagem Tat, cujos elementos apresentaram regiões não codificantes de tamanho variável depois da região da Pol (Figura 2.1).

\subsection{2 sRNAs}

A população de sRNA foi organizada em duas classes: 20 a 22 nucleotídeos e 23 a 25 nucleotídeos. Deste ponto em diante essas classes serão chamadas de $21 \mathrm{nt}(20-22 \mathrm{nt})$ e $24 \mathrm{nt}$ (23-25nt). Nesta análise permitimos 1 ou 2nt de mismatch entre cada sRNA e a sequência referência de LTR-RT. Obtivemos alinhamento perfeito em $25 \%$ e $22 \%$ entre os LTR-RT referência e os sRNA das classes 21 e 24nt, respectivamente. Na linhagem Maximus, todas as famílias apresentaram mais de 8000 sRNA mapeados à suas sequências referência, em sua maioria pertencentes à classe de 24nt (Figura 2.3; APÊNDICE C e APÊNDICE D). Estes elementos tiveram a maior contagem de sRNA, entre 1,5 e 5,5 vezes maior do que as outras linhagens, sendo que a maioria dos alinhamentos ocorreu nas LTR destes elementos (Figura 2.3; APÊNDICE C). Del1 é a única família dentro de Gypsy que apresentou um grande número de sRNA mapeados à sua cópia de referência. As linhagens Ivana e Reina foram as que apresentaram menor número de sRNA mapeados à suas referências (APÊNDICE D). Dentro da linhagem Ivana, o elementos RLC_scIvana6.1 apresentou o maior número de sRNA mapeados, sendo a maioria deles da classe 21nt (APÊNDICE D). O mesmo padrão foi observado em RLG_Reina3.1. As outras famílias dessas duas linhagens apresentaram um número muito baixo de sRNA mapeados às cópias de referência. 

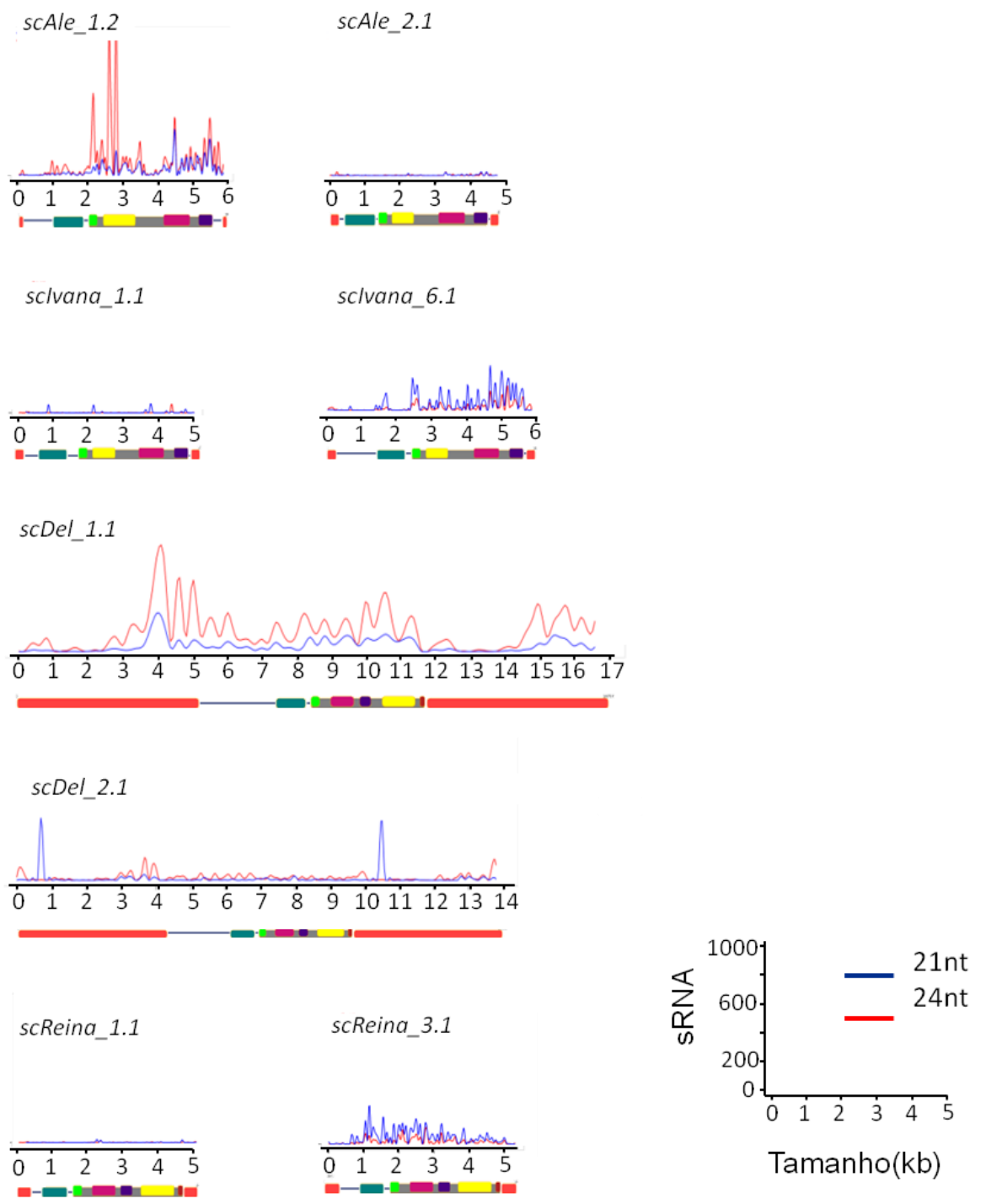

Figura 2.3 - Mapeamento de sRNA em famílias de LTR-RT de cana-de-açúcar. Mapeamento de sRNA em sequência referência de 8 famílias de LTR-RT. sRNA de 20-22nt estão representados pelas linhas azuis, enquanto sRNA de 23-25nt sRNAs estão representados por linhas vermelhas. Uma representação esquemática de cada elemento está posicionada abaixo de seu respectivo gráfico de mapeamento, e segue o padrão de cores definido nas Figuras 2.1 e 2.2. Uma escala está localizada no canto inferior da figura.

A distribuição de sRNA nas LTRs e regiões codificantes das cópias referência (APÊNDICE C) foi realizada e diversos padrões de distribuição foram identificados, tanto nas LTRs como no corpo dos elementos em estudo. Famílias da linhagem Maximus e a família Del1 apresentaram alta contagem de 24 nt sRNA em suas LTRs. A região 5' de ambas as LTRs das cópias representativas das famílias Del2 e Del3 apresentaram um pico de 21nt sRNA, de função desconhecida. A maioria das famílias estudadas não apresentou contagem de sRNA elevada em sua região codificante, com apenas algumas exceções. Entre essas exceções, a família Ale1 apresentou o padrão mais intrigante, com mais de mil sRNA da classe 24nt mapeados entre os domínios codificantes de sua integrase e protease. A família Tat2 por sua vez teve mais de seis mil sRNAs da classe 24 nt mapeados no domínio 
codificante de sua RNAseH (APÊNDICE C). Todos os outros casos de alto número de sRNAs mapeados em regiões codificantes estão relacionados a classe $21 \mathrm{nt}$, como é o caso das famílias Ivana6 e Reina3, ambas apresentam por volta de trezentos sRNAs desta classe distribuídos ao longo de seu corpo. Curiosamente, a família Angela2 apresentou picos de mais de duzentos sRNA de 24nt mapeados em uma região não codificante presente entre o domínio da Gag e sua LTR (APÊNDICE C).

\subsubsection{Atividade transcricional}

A partir do SUCEST, 84 transcritos do cultivar SP80-3280 foram associados a cópias completas de LTR-RTs. O maior número de transcritos encontrados foi na biblioteca de raiz (Figura 2.4b), seguida pelas bibliotecas de internó, gema lateral e calo.

A superfamília Copia foi mais representada no banco de transcritos do que a Gypsy, com 51 e 33 sequências, respectivamente (Figura 2.4a). Transcritos previamente descritos (ARAUJO et al., 2005a) foram associados a 8 das 35 famílias identificadas nos BACs (APÊNDICE E). Durante o estudo, foram encontrados ESTs para 14 famílias (Figura 2.4a) que não eram descritas como ativas em cana-de-açúcar (ARAUJO et al., 2005a; ROSSI; VAN SLUYS, 2001) (Figura 2.4a), entretanto não encontramos nenhuma EST correspondente à família Ale3, que havia sido descrita como ativa. 
A

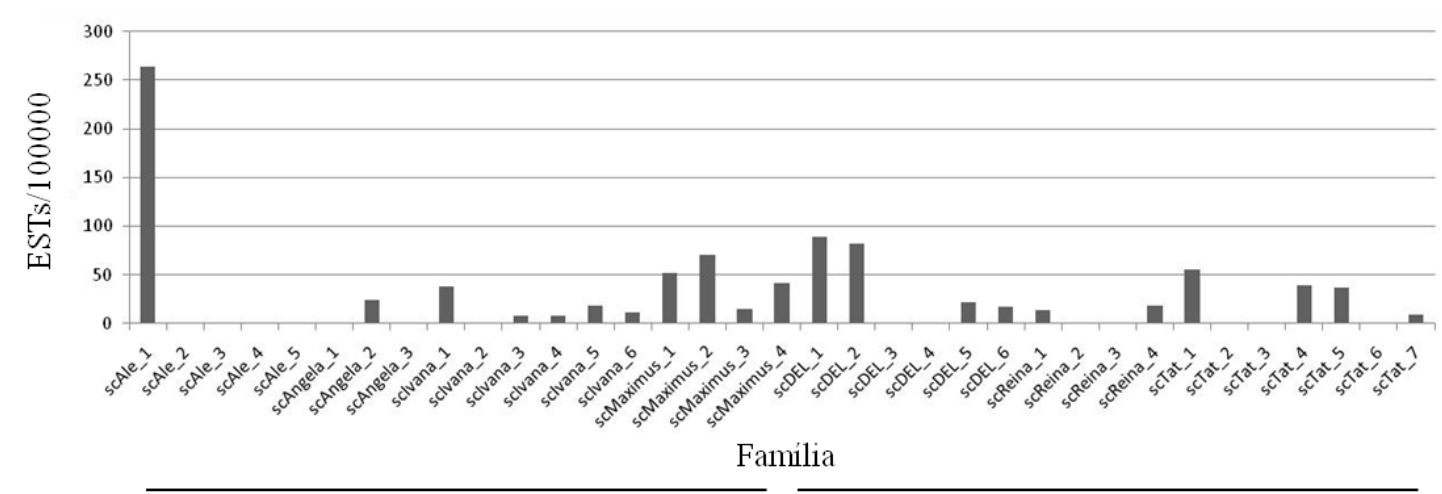

Copia

Gypsy

B

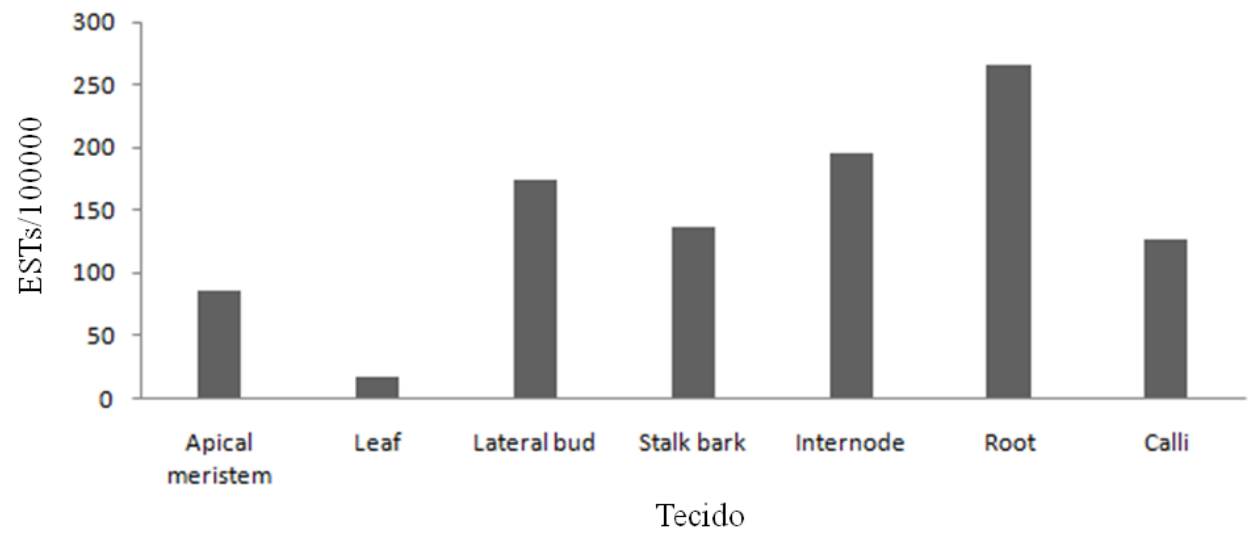

Figura 2.4 - Atividade transcricional de LTR-RTs de cana-de-açúcar. ESTs do cultivar SP80-3280 disponíveis no NCBI foram assinaladas a uma família de LTR-RT, através do critério descrito por Wicker et al. (2007). (a) Número total e normalizado de ESTs associados a cada família de LTR-RT e (b) Número de ESTs por 100.000 transcritos encontrados em cada tecido.

\subsubsection{In situ}

Com o objetivo de verificar a localização tecido-específica da expressão em raiz, lâminas foram montadas conforme descrito em material e métodos. É possível observar o tecido cortical da raiz primária (rico em aerênquimas) circundando o cilindro vascular. Primórdios de raízes laterais interrompem a formação do aerênquima, e posteriormente prolongamentos de córtex e tecido vascular em diferenciação se evidenciam (Figuras $2.5 \mathrm{e}$ 2.6). Sabemos que a formação dos aerênquimas em raízes de cana de açúcar depende da morte celular de milhares de células corticais. Nossa hipótese inicial era de que os altos níveis expressão dos retrotransposons na raiz estariam associados à morte celular programada. 


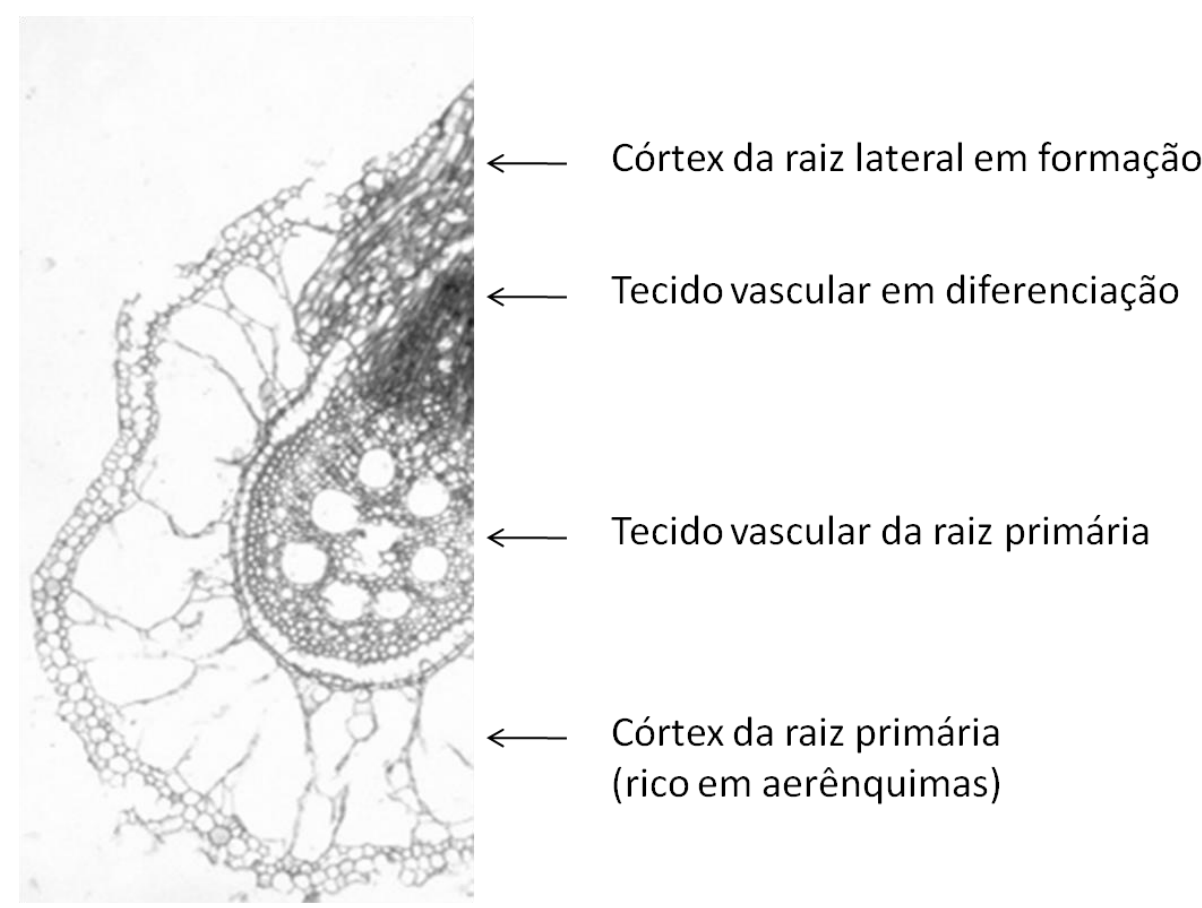

Figura 2.5 - Exemplo de corte transversal de raiz de cana-de-açúcar no momento do surgimento de uma raiz lateral. As setas indicam tecidos importantes para a nossa discussão.

Diferentemente de nossa hipótese, descobrimos que estes retrotransposons estão sendo transcritos em abundância nas raízes laterais (região azulada na Figura 7). Essa intensa expressão ocorre mais precisamente, nos tecidos corticais e vasculares gerados durante a formação de raízes laterais, tecidos estes que aparentam estar em fase de diferenciação acompanhada de divisão celular acentuada nesta região. 

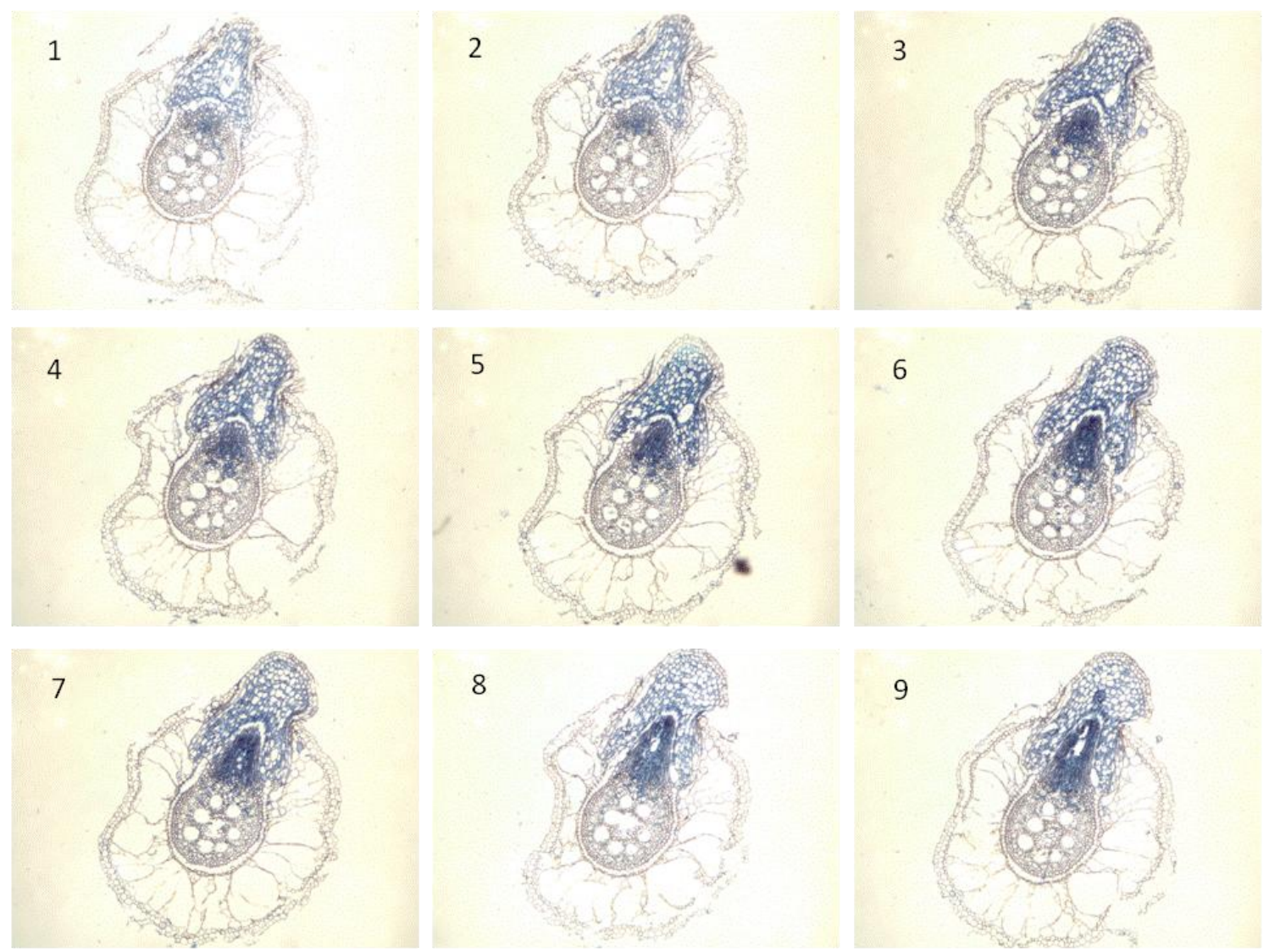

Figura 2.6 - Hibridização em série de cortes transversais sequenciais (1 a 9) de raiz de cana-de-açúcar no momento do surgimento de uma raiz lateral. A sonda utilizada foi referente à família scAle1 (anti-senso).

\subsubsection{Networks e padrões de metilação}

Utilizando iniciadores que foram desenhados em regiões conservadas do domínio proteico da transcriptase reversa (RT) de três famílias distintas de elementos das linhagens Ale1, Del1 e Maximus1 em cana-de-açúcar foi possível analisar a diversidade de elementos encontrados nestas famílias. A amplificação de fragmentos de RT sobre DNA genômico de dois parentais (S.spontaneum e S.officinarum) e dois cultivares modernos (R570 e SP803280) e posterior sequenciamento destas, possibilitou a construção de diagramas de network. Esses diagramas se mostraram mais sensíveis do que árvores filogenéticas para a interpretação dos resultados oriundos do sequenciamento.

Aproximadamente 700 fragmentos foram amplificados, clonados e sequenciados, distribuídos conforme apresentado na Tabela 2.2. Após alinhar estes fragmentos, construímos diagramas de network para cada família selecionada. 
Tabela 2.2 - Número de sequências no alinhamento final

\begin{tabular}{cccc}
\hline \hline & \multicolumn{3}{c}{ Linhagem } \\
\hline Variedade & Ale & Del & Maximus \\
\hline Mandalay & 68 & 36 & 45 \\
Badila & 76 & 45 & 43 \\
SP80-3280 & 45 & 46 & 45 \\
R570 & 37 & 47 & 46 \\
R570NM & 38 & 31 & 40 \\
BAC & 4 & 4 & 10 \\
\hline Total & 268 & 209 & 229 \\
\hline \hline
\end{tabular}

O diagrama de network da família scAle1 ressalta dois agrupamentos (Figura 2.7), onde a maioria das sequências se encontra no grande agrupamento presente na metade inferior da figura. Este grupo é homogêneo e sugere que os parentais S.spontaneum e S.officinarum contribuíram de maneira equivalente para a composição dos genomas dos cultivares modernos estudados, ao menos quando consideramos essa família de retrotransposons. Nota-se a presença de dois círculos que compartilham sequências de origem distintas e há pelo menos 4 círculos visíveis que apresentam tamanho maior que as demais. 


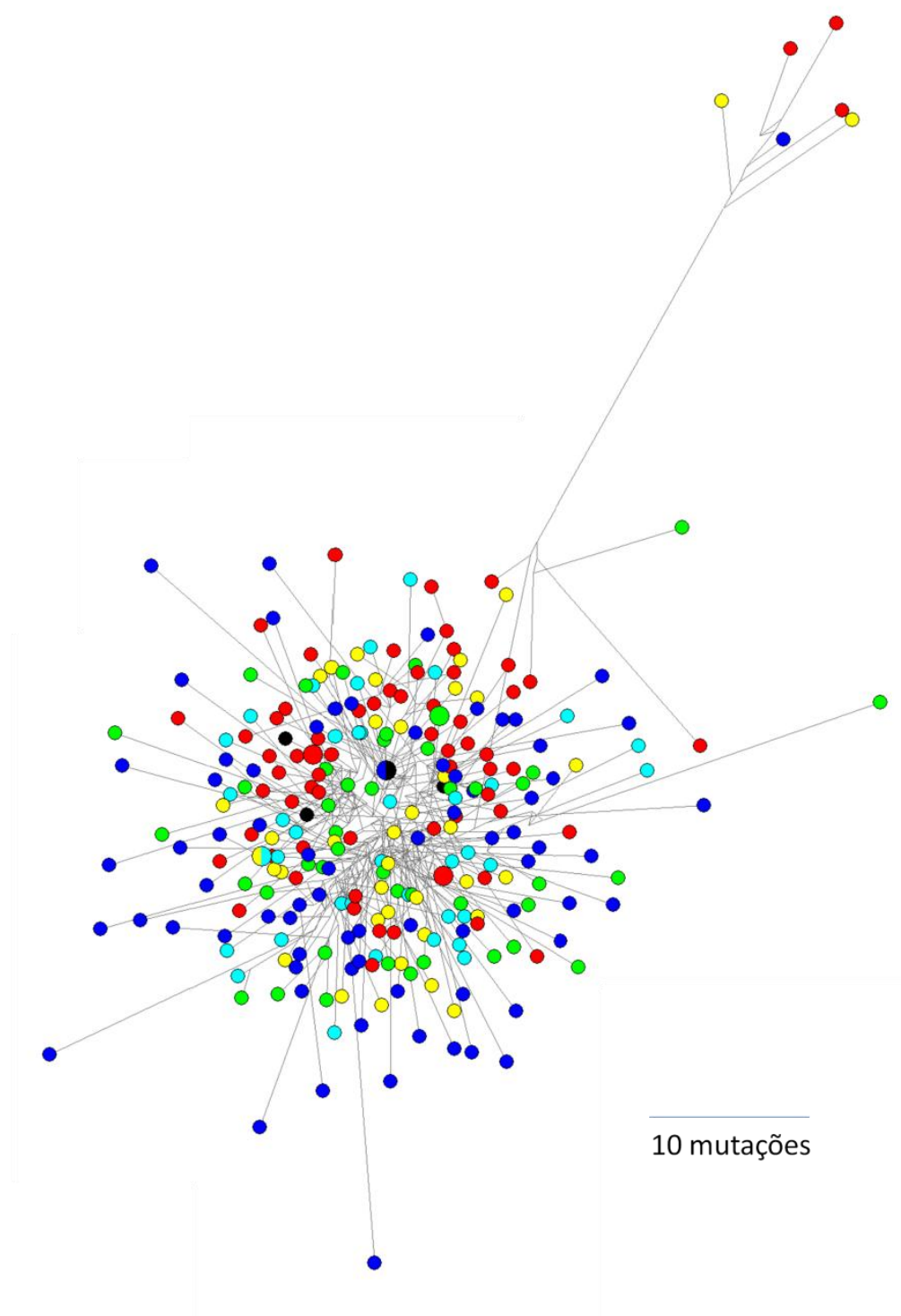

Figura 2.7 - Diagrama de network de scAle1. Contendo sequências das transcriptases reversas: de ambos os parentais Saccharum oficcinarum (azul escuro) e Saccharum spontaneum (vermelho); dos cultivares R570 (amarelo) e SP803280 (verde); das sequências não metiladas de R570 (azul claro) e dos elementos completos oriundos de BACs (preto). O tamanho do círculo corresponde ao número de sequências nele contidas.

Ao analisarmos o diagrama de network da família scDel1 (Figura 2.8) encontramos um panorama diferente, há dois agrupamentos distintos e um grande número de sequências em cada. Na metade inferior da figura é possível distinguir um grande número de sequências provenientes de S.spontaneum (círculos vermelhos) e com poucas sequências derivadas de híbridos modernos. Já na metade superior da figura encontramos um grande número de sequências derivadas de S.officinarum e dos dois híbridos modernos (R570 e SP80-3280). 
Junto com esse agrupamento é possível distinguir os círculos azul claro, que representam as sequências não metiladas de R570.

Isto sugere que os parentais tiveram contribuição distinta no conjunto de elementos da família Del1 para a composição dos genomas modernos. Podemos propor que grande parte dos elementos Del1 presentes nos cultivares modernos estudados são contribuição do genoma de S.officinarum.

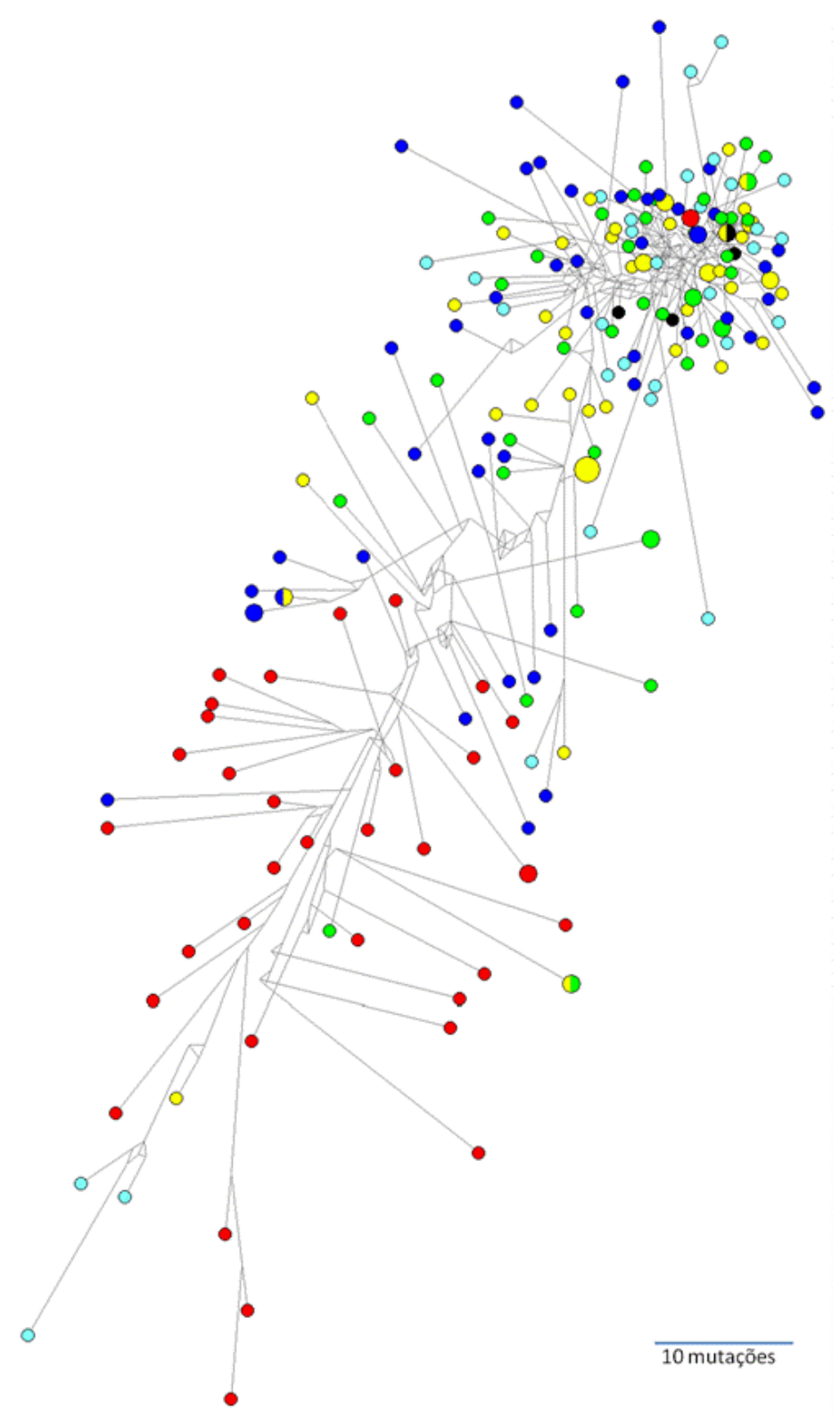

Figura 2.8 - Diagrama de network de scDel1. Contendo sequências das transcriptases reversas: de ambos os parentais Saccharum oficcinarum (azul escuro) e Saccharum spontaneum (vermelho); dos cultivares R570 (amarelo) e SP803280 (verde); das sequências não metiladas de R570 (azul claro) e dos elementos completos oriundos de BACs (preto). 
O diagrama de network gerado a partir das sequências de scMaximus1 apresenta um padrão distinto dos elementos anteriores. Fica bastante evidente na parte superior direita da figura 2.9 um grande agrupamento, bastante semelhante ao agrupamento principal de scAle1 (chamado de Grupo I). Porém nota-se um acúmulo de sequências oriundas de S.spontaneum e uma maior dispersão das sequências de S.officinarum com a formação de uma cauda bastante divergente do nodo central (chamada de Grupo II). Podemos concluir que ambos parentais contribuíram para a composição de scMaximus1 nos genomas de cultivares modernos no entanto há uma clara concentração de sequências relacionadas a S.spontaneum na rede.

Em contrapartida podemos observar o Grupo II de sequências, no canto inferior esquerdo da figura, composta majoritariamente por sequências de SP80-3280, R570 (BACs e não metiladas) e algumas sequências de S.officinarum. A existência de um grande número de sequência oriundas de BACs no Grupo II nos levou a explorar suas sequências completas, como descrito no próximo tópico.

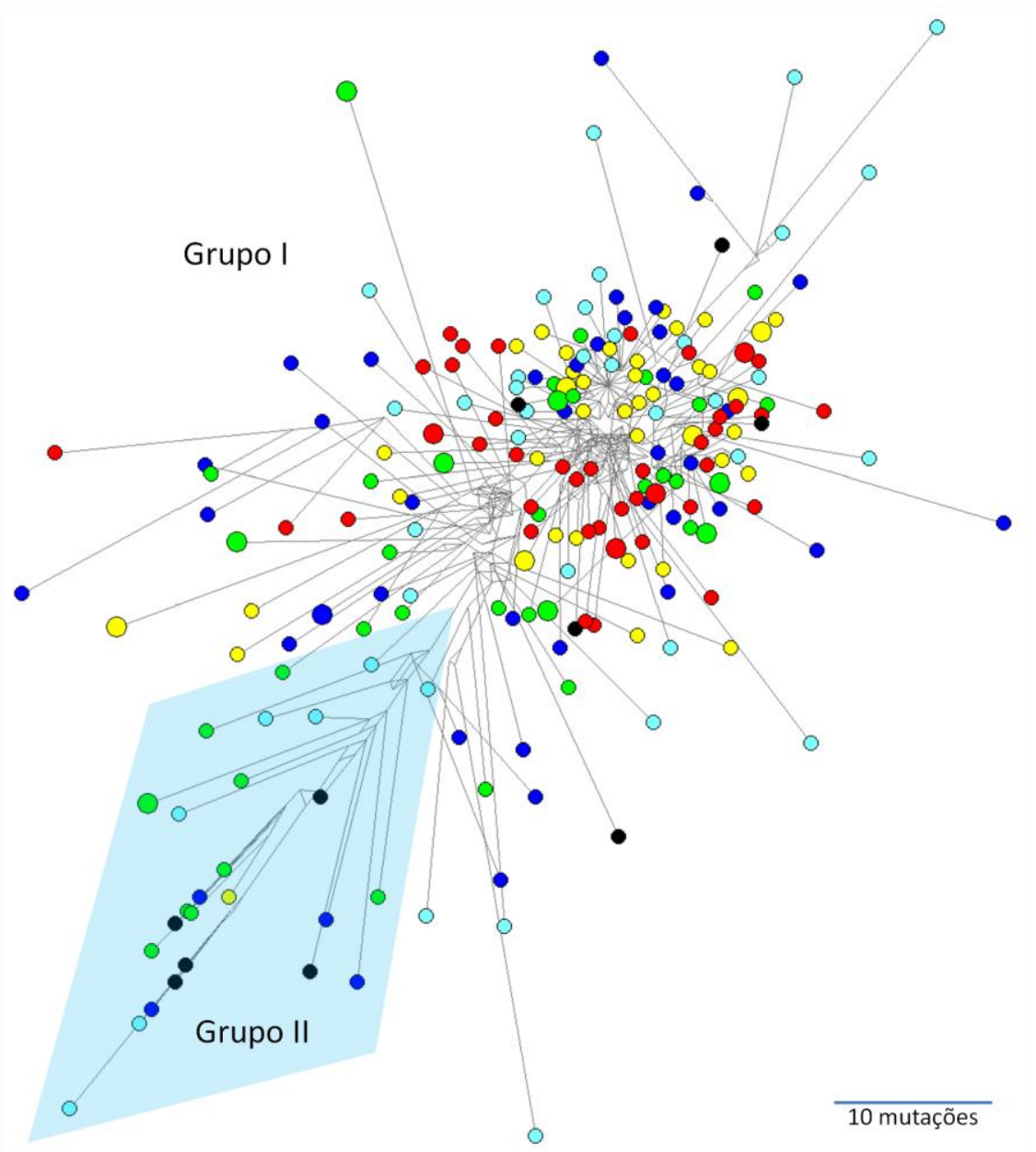

Figura 2.9 - Diagrama de network de scMaximus1. Contendo sequências das transcriptases reversas: de ambos os parentais Saccharum oficcinarum (azul escuro) e Saccharum spontaneum (vermelho); dos cultivares R570 (amarelo) e SP803280 (verde); de sequências não metiladas de R570 (azul claro) e dos elementos completos oriundos de BACs (preto). 


\subsubsection{RMs Maximus}

Os diagramas de network para estudos de diversidade são uma ferramenta poderosa para subclassificação de elementos de transposição. A formação de subgrupos, mesmo que originadas por um alinhamento da transcriptase reversa, pode dar pistas importantes sobre a evolução destes elementos. No caso da família Maximus1, ao explorar suas sequências completas, observamos que algumas de suas cópias possuíam pequenas deleções em suas LTRs. Essas deleções se encontravam logo acima do TATA Box putativo (120 pares de base de distância). Construímos um alinhamento múltiplo de todas as LTRs de Maximus1 inclusas no network e, ao sobrepor as duas análises, ficou claro que havia uma organização. Dois agrupamentos distintos nas sequências de scMaximus1 (Figura 2.9). Nesse caso havia cópias completas desse elemento, retiradas de BACs, em ambos os agrupamentos. Os agrupamentos desse elemento foram denominados I e II, onde I é o grupo majoritário, e II não possui nenhuma sequência oriunda de Mandalay (S.spontaneum).

A presença de elementos completos (Tabela 2.3) nos dois grupos de scMaximus1 permitiu que as cópias fossem comparadas a nível estrutural. Podemos observar no alinhamento (Figura 2.10) a presença de duas inserções nos elementos do grupo II. Enquanto a inserção "B" é causada pelo aumento do número de motivos repetidos característicos deste clado (Pearce et. al, 2010) a inserção " $A$ " aparentemente surgiu com a duplicação de uma região sem precedentes na literatura.

Tabela 2.3 - Identificação das cópias completas presentes no diagrama de network de scMaximus1

\begin{tabular}{ccc}
\hline \hline Grupo & Identificação do LTR-RT & Identificação do BAC \\
\hline \multirow{4}{*}{ I } & R10 & SHCRBa-086-H20 \\
& R19 & SHCRBa-041-J05 \\
& R25 & SHCRBa-230-N09 \\
& R57 & SHCRBa-115-J16 \\
& R68 & SOG_003_E12 \\
\hline \multirow{3}{*}{ II } & R5 & SHCRBa-095-F04 \\
& R15 & SHCRBa-201-A23 \\
& R32 & SHCRBa-145-F07 \\
& R50 & SHCRBa-258-H24 \\
& R61 & SHCRBa-170-C07 \\
\hline \hline
\end{tabular}



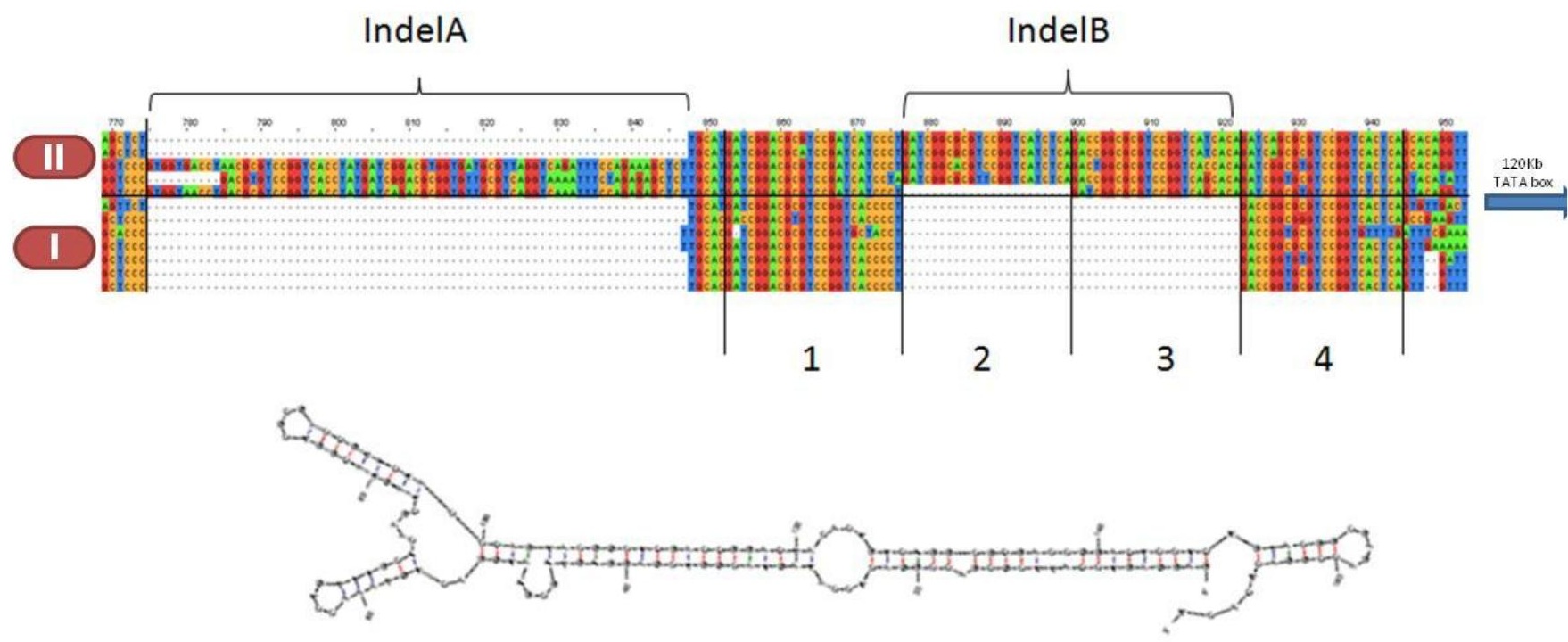

Figura 2.10 - Porção do alinhamento da LTR de scMaximus1. Os agrupamentos I e II são os grupos relativos à figura 10. As duas regiões de inserção estão representadas por IndelA e IndelB. IndelB é formado por um motivo repetido. Esta região encontra-se a $120 \mathrm{pb}$ a montante do TATA Box.

A análise de busca por estruturas secundárias revelou que cada motivo repetido da inserção "B" (2-3 internos e 1-4 flanqueadores) forma um pequeno grampo e que estes motivos quando juntos formavam grampos ainda maiores (Figura 2.11). 


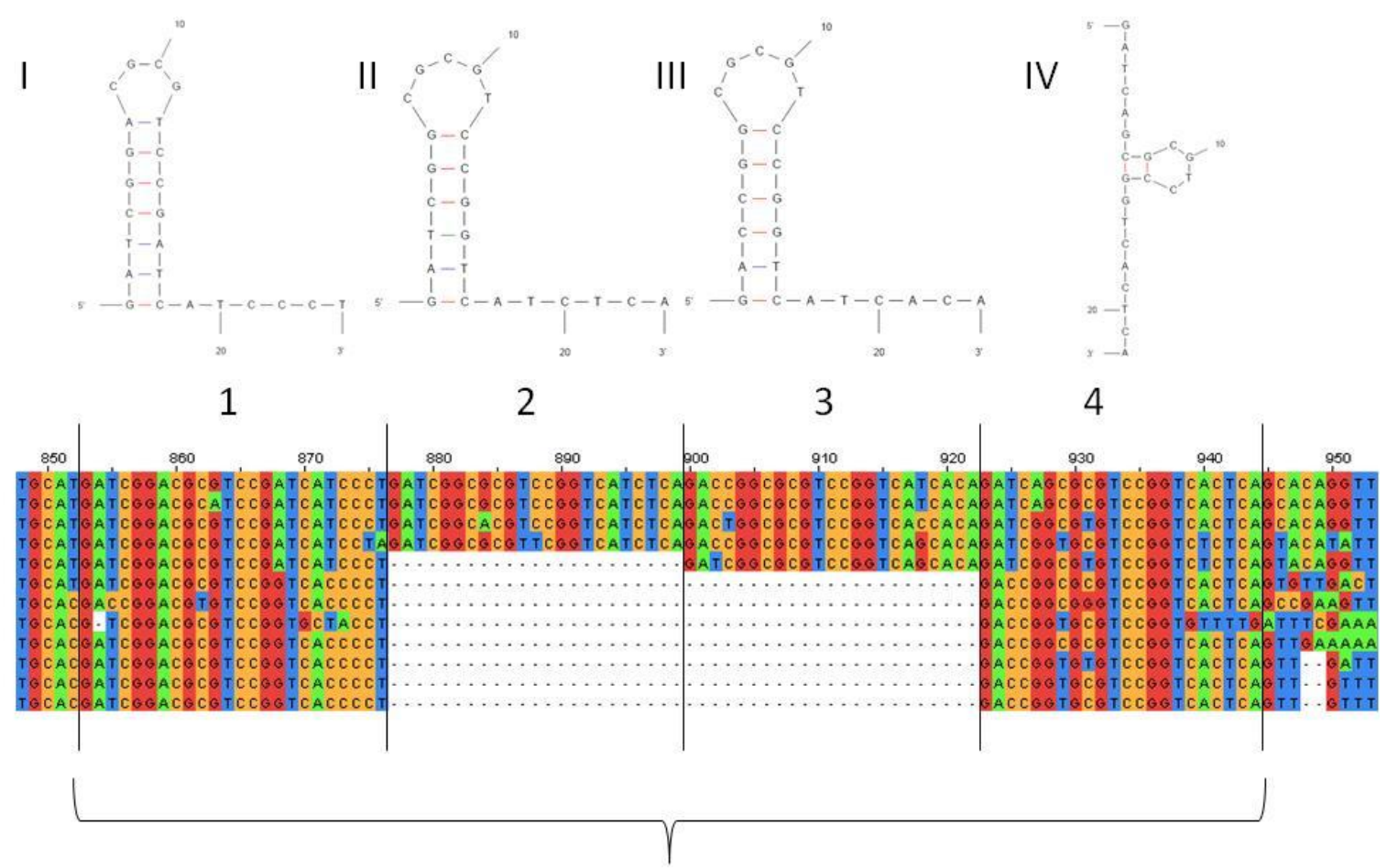

V

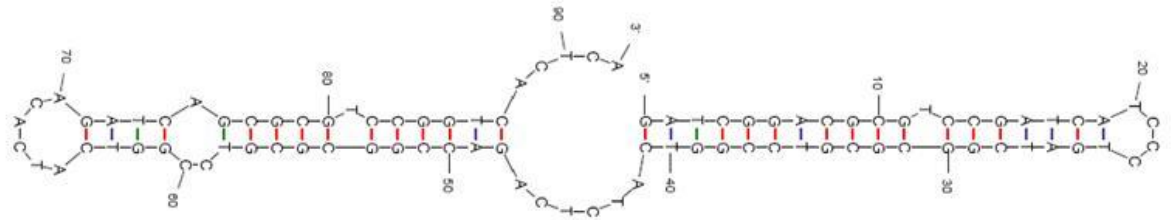

Figura 2.11 - Diagramação da estrutura secundária dos motivos repetidos da LTR de Maximus. Formada por cada um dos motivos 1 a 4 (I a IV, respectivamente) e do começo do motivo repetido 1 ao final do motivo repetido $4(\mathrm{~V})$ da região contendo o Indel B.

\subsection{Discussão}

Neste capítulo são descritos os elementos LTR-RTs provenientes do genoma de canade-açúcar encontrados em sequências de BACs produzidas no projeto BIOEN e disponíveis no NCBI. A descrição desses elementos engloba suas características estruturais, de expressão e diversidade. Trinta e cinco famílias de LTR-RT foram identificadas no genoma de cana de açúcar e esses distribuem-se em quatro linhagens da superfamília Copia e três linhagens da superfamília Gypsy. Estabelecemos que cada família apresenta um padrão único e específico em relação a sua estrutura, atividade transcricional e mapeamentos de pequenos RNAs. Além disso, exploramos mais profundamente a diversidade e comportamento de três famílias com características contrastantes: scAle1, scDel1 e scMaximus1. 


\subsubsection{LTR-RTs possuem características estruturais diversas e pertencem a linhagens evolutivas compartilhadas entre monocotiledôneas e eudicotiledôneas}

Estudos prévios sobre LTR-RTs em plantas definiram seis grandes linhagens evolutivas que compõem a superfamília Copia (WICKER; KELLER, 2007) e seis linhagens que definem a superfamília Gypsy (LLORENS et al., 2011). Bianca foi a única linhagem da superfamília Copia em que não foram encontradas cópias completas na amostragem genômica disponível em cana-de-açúcar. A ausência de elementos da linhagem Bianca em nosso estudo pode ser explicada por sua relativa baixa representatividade em outros genomas vegetais. Até o momento todas as cópias completas de elementos dessa linhagem descritas se resumem a algumas famílias descritas em arroz (WICKER; KELLER, 2007) e uma família descrita em soja (DU et al., 2010).

Também não foram encontrados elementos das linhagens Galadriel e CRM, ambas pertencentes à superfamília Gypsy. A linhagem Galadriel é pouco representada dentre as monocotiledôneas, aparecendo apenas algumas cópias descritas em banana (HRIBOVÁ et al., 2010). Elementos da linhagem $C R M$ são pouco representados quando comparados a outras linhagens da superfamília Gypsy no genoma de arroz (DU et al., 2010), outra gramínea, o que pode explicar em parte a ausência de elementos desta linhagem no conjunto de BACs estudados. Elementos $C R M$ foram identificados em estudo realizado por nosso grupo, posterior a este trabalho, em que outros BACs de cana-de-açúcar foram analisados (manuscrito em preparação).

Quando realizamos este estudo, apenas uma pequena parte do genoma da cana-deaçúcar havia sido sequenciada, mesmo assim, o número de famílias de LTR-RT identificadas é comparável àquele encontrado em trabalhos semelhantes com BACs de Medicago truncatula (232 Mb) (WANG; LIU, 2008) e Capsicum annuum (35.6 Mb) (PARK et al., 2011), o que sugere que temos um bom panorama da diversidade de LTR-RTs presentes no genoma de cana-de-açúcar.

Para entender melhor a micro diversidade destes elementos, escolhemos três famílias com características estruturais bastante distintas: scAle1, scDel1 e scMaximus1. Os diagramas de network apresentados sugerem que S.spontaneum e S.officinarum contribuíram de maneira distinta para a composição dos genomas dos cultivares modernos estudados. A família scDel1 apresenta o padrão mais interessante, onde os parentais tiveram contribuição diferenciada na composição de elementos para os genomas de cultivares modernos, uma vez que grande parte dos elementos Del1 presentes nesses genomas assemelham-se a elementos de S.officinarum. É 
interessante notar que este estudo pode contribuir para a identificação de regiões genômicas relevantes à composição dos cultivares modernos ricos em açúcar no colmo. Elementos compartilhados entre todos os genomas podem denotar regiões estruturais dos cromossomos (telômeros ou centrômeros) ou ainda associação dos elementos a regiões genômicas características de Saccharum. O diagrama de network de scMaximus1 por outro lado apresenta uma estrutura interessante onde há proximidade de BACs com S. Officinarum e outros BACs para S.spontaneum.

A inclusão de fragmentos não metilados nos diagramas de network mostrou-se uma ferramenta relevante para monitorar alterações epigenéticas potenciais. Apenas no caso de scAle1 nota-se uma distribuição heterogênea das sequências não metiladas enquanto que para scDel1 e scMaximus1 essas sequências encontram-se distribuídas por toda rede. Finalmente, nota-se que esses fragmentos agrupam-se nos diagramas próximos às sequências de cultivares modernos.

A presença de muitas sequências derivadas de elementos completos extraídos de BACs no diagrama de network de scMaximus1 possibilitou o estudo mais aprofundado de sua estrutura. Observamos que elementos completos que se encontram no agrupamento principal de sequências deste diagrama apresentam menos cópias de motivos repetitivos nas LTRs do que aqueles que se encontram afastados desse agrupamento. Esses motivos repetitivos mostraram-se parte de uma complexa estrutura secundária, que se expande à medida que mais motivos são adicionados. Mais estudos mostram-se necessários para compreender a função dessas estruturas secundárias, mas acreditamos que essas estão diretamente ligadas à regulação transcricional dos elementos da linhagem. Assim sendo, a presença ou ausência dessas inserções poderiam levar a um perfil transcricional distinto entre elementos dos Grupos I e II.

\subsubsection{Atividade transcricional de LTR-RTs e pequenos RNAs associados}

Elementos de transposição estão presentes em grande número nos genomas das gramíneas, e muitas vezes são transcricionalmente ativos. Uma busca muito rigorosa por transcritos de cana-de-açúcar relacionados à TEs confirmou que atividade transcricional é uma característica comum entre diversas famílias de LTR-RT nesse genoma, como já foi demonstrado para outras gramíneas (ECHENIQUE et al., 2002; VICIENT, 2010). Vale ressaltar que dentro de cada linhagem o número de transcritos mapeados para cada família variou muito (Figura 2.4a). O melhor exemplo disso são as famílias da linhagem Ale, onde 
encontramos a família com maior número de transcritos associados (Ale1) ao lado de famílias pouco ativas. Esse padrão de linhagens com famílias muito ativas tanscricionalmente, ao lado de famílias pouco ativas, se repete, à exceção da linhagem Maximus onde, para todas as famílias estudadas, um número similar de transcritos foi identificado.

Quando separamos esses transcritos por biblioteca, o tecido mais representado, após normalização, foi a raiz (Figura 2.4b), seguida por internos, gema lateral e calo. Um estudo em cana-de-açúcar anteriormente conduzido por nosso grupo de trabalho havia identificado calo como o tecido onde ocorre a maior atividade destes elementos (ARAUJO et al., 2005a), entretanto o estudo em questão considerou apenas as biblioteca de calo, meristema apical, folha e flor. As diferenças de expressão desses elementos em diferentes tecidos podem guiar estudos futuros sobre TEs em cana-de-açúcar.

Devido ao seu potencial mutagênico, a atividade de LTR-RTs é geralmente mantida sobre o controle do genoma. Esse controle se dá através de uma complexa maquinaria que tem em seu cerne os pequenos RNAs, mais precisamente os RNAs de interferência (siRNA). Essa maquinaria entra em ação assim que detectado um RNA aberrante. A natureza proliferativa dos TEs aumenta a probabilidade da produção de transcritos senso e anti-senso, gerando RNAs dupla fita (dsRNA) e ativando a maquinaria de siRNA.

Em plantas, duas classes de siRNAs já foram bem descritas e estudadas. A primeira é composta por pequenos RNAs de 21 nucleotídeos e é responsável pela regulação pós transcricional de mRNAs. A segunda classe possui 24 nucleotídeos e está envolvida na regulação transcricional, onde através de metilação do DNA genômico leva a supressão da expressão do gene ou elemento alvo (BAULCOMBE, 2004).

Estudo anteriores mapearam sRNAs sobre os LTR-RTs encontrados nos genomas de trigo e milho (NOBUTA et al., 2008; CANTU et al., 2010), e mostraram um padrão geral de acúmulo de 24-nt siRNAs nas LTRs destes elementos. Em nosso estudo optamos por mapear esses siRNAs em cópias individuais destes elementos, e ao invés de sobrepor o padrão de mapeamento buscamos identificar como estão distribuídos esses siRNAs ao longo de cada família de LTR-RT, dentro de cada linhagem presente no genoma de cana-de-açúcar.

O padrão previamente descrito de 24-nt nas LTRs foi encontrado em todas as cópias referência da linhagem Maximus e para as referências das famílias Del1 e Tat3 (APÊNDICE D), enquanto as demais famílias estudadas apresentaram diferentes padrões. Quase a metade das famílias (18 de 33) apresentou um número baixo de sRNAs $(<2000)$ mapeados à sua cópia de referência (APÊNDICE D). Dois outros padrões foram observados, o primeiro consiste em um alto número de 21-nt sRNAs mapeados na região codificante do elemento, 
intra LTRs, representado pelas famílias Ivana6 e Reina3 (APÊNDICE D), e o segundo padrão consiste em muitos 24-nt sRNAs mapeados na região codificante do elemento, encontrado apenas na família Ale 1.

Poucos sRNAs mapeados a um elemento pode ser um indicativo de que esse elemento não está ativo ou entrou em atividade muito recentemente, e ainda não foi detectado pela maquinaria de silenciamento. Se o elemento não estiver ativo ele provavelmente está sendo mantido silenciado por metilação. Um estudo anterior mostrou que, $\sim 63 \%$ das regiões metiladas do genoma são mantidas nesse estado, sem ser alvo constante de sRNAs (ZHANG et al., 2006). Esse fato poderia explicar a ausência de sRNAs de 21 e 24 nt em diversas cópias estudadas.

O padrão encontrado na família Ale 1 é único e sugere que a maquinaria de metilação do DNA a partir do RNA (RdDM) está levando à metilação da região codificante de cópias desse elemento no genoma da cana-de-açúcar. O conceito de "metilação do corpo do gene" (tradução livre do termo original em ingles: "body-methylated gene") foi descrito pela primeira vez em plantas em 2006, quando Zhang e colaboradores mostraram que mais de um terço dos genes expressos em Arabidopsis possuíam a região codificante metilada, ao contrário de seus promotores (ZHANG et al., 2006). A família Ale1 é particularmente interessante em cana-de-açúcar, ela não só possui o padrão de "metilação do corpo do gene", como é o LTR-RT mais ativo em cana-de-açúcar, e está concentrada nas regiões eucromáticas e ricas em gene desse genoma ((JANNOO et al., 2007) e Figura 2.3). Neste momento não podemos tirar conclusões dessas observações, mas os resultados são intrigantes e merecem destaque em estudos futuros.

Com o uso da hibridação in situ foi possível estudar com mais detalhes o comportamento dos elementos desta família nas raízes de cana-de-açúcar. A hipótese inicial que motivou o estudo é que a morte celular durante a geração de aerênquimas levaria ao descontrole e a um aumento de atividade destes elementos. Nossa hipótese não foi confirmada, já que foi observado uma intensa e inesperada atividade transcricional de elementos dessa família nos primórdios de raízes laterais. Hoje acreditamos que durante a desdiferenciação/diferenciação essas células passam por um remodelamento epigenético, que levaria ao aumento da expressão dos retrotransposons em geral. Experimentos futuros poderão abordar este assunto visando entender o perfil transcricional e o estado epigenético de diversos genes e elementos de transposição nestes tecidos. 


\subsection{Conclusão}

Este é o primeiro estudo a realizar um levantamento concomitante de diversidade filogenética, estrutura, atividade transcricional e interação com sRNAs de LTR-RTs em um genoma vegetal. Nós classificamos 60 elementos LTR-RT dentre 35 famílias pertencentes a quatro linhagens da superfamília Copia e três da superfamília Gypsy. Para a análise de transcrição e o mapeamento de sRNA optamos por analisar a nível familiar, para evitar a sobreposição de padrões. Cada família apresentou um perfil mapeamento de sRNA e transcricional distinto, sugerindo que cada família pode ser diferencialmente expressa e regulada, mesmo quando pertencentes a uma mesma linhagem. A família Ale 1 mostrou-se particularmente interessante, pois apresentou um padrão de mapeamento de sRNA incomum, sugerindo a metilação de sua região codificante. Além disso, esta família é a mais ativa dentre todos os LTR-RT estudados em cana-de-açúcar e se concentra nas regiões eucromáticas (DOMINGUES et al., 2012). No geral, estes resultados sugerem que os elementos LTR-RTs apresentam formas distintas de interação com o genoma hospedeiro e que devemos, para melhor entender estas interações, analisar esses elementos a nível familiar.

Através de hibridização in situ demonstramos que as altas taxas de transcrição, de retrotransposons da família scAle1, em sistemas radiculares de cana-de-açúcar ocorrem durante a formação de raízes laterais. Nossa análise de micro-diversidade, por sua vez, indica que os parentais (S.spontaneum e S.officinarum) podem contribuir de distintamente para a composição dos genomas dos cultivares modernos, dependendo da família estudada. Esta última observação pode ser um dos mecanismos preliminares do processo de especiação e ainda poderia auxiliar na identificação das características genéticas/genômicas do genoma de S. spontaneum mantidas pelos programas de melhoramento do híbrido moderno. 


\section{CAPÍtULO 2}

Algumas observações feitas no capítulo 1 desta tese nos estimularam a realizar os experimentos apresentados neste segundo capítulo. Entre essas observações está a de que elementos que pertencem a famílias diferentes dentro da mesma linhagem possuem comportamentos distintos, quanto ao mapeamento de sRNA e expressão transcricional. Além disso, observamos que a linhagem Del possui o maior tamanho de LTR dentre as linhagens estudadas e que a variação no tamanho dos elementos desta linhagem em cana ocorre devido à variação no tamanho de suas LTRs. Começamos então este segundo capítulo com o objetivo de entender melhor a estrutura dos elementos de diferentes famílias da linhagem Del, em diversos genomas vegetais.

\subsection{Introdução}

A região codificante de TEs são relativamente bem conservadas entre gêneros e reinos, por este motivo são comumente utilizadas para gerar análises filogenéticas (MANETTI et al., 2009; XIONG; EICKBUSH, 1990). Dentre as regiões não codificantes a LTR é a mais variável (VERNHETTES et al., 1998;) e é dividida estruturalmente em três regiões bem definidas: U3, R e U5. Em plantas, os TEs geralmente se encontram em estado silenciado através da metilação dessa região (SLOTKIN; MARTIENSSEN, 2007) e como visto no capítulo anterior, a LTR é um dos alvos de pequenos RNAs (CANTU et al., 2010; DOMINGUES et al., 2012). O promotor e outros elementos regulatórios se encontram na U3 (KUMAR; BENNETZEN, 1999) sendo esta uma região chave para a regulação dos elementos LTR-RTs.

Os LTR-RTs se assemelham a vírus em sua estrutura e mobilidade, à exceção de sua incapacidade de se movimentar de célula a célula (PERLMAN; BOEKE, 2004). Tanto em retrovírus quanto em LTR-RTs a integração é mediada por uma proteína denominada integrase. O mecanismo de integração mediada por esta proteína é dependente da presença de sítio de ligação/associação, conhecidos na literatura como sítios att (do inglês; attachment sites). Os sítios att são conservados e localizam-se um na extremidade 5' e outro na 3' tendo sido identificados em retrovírus. O reconhecimento de sítios att pela integrase viral confere especificidade ao processo de integração (BROWN et al., 1999; CHIU; GRANDGENETT, 2000; MASUDA et al., 1998). Apesar das semelhanças estruturais entre LTR-RTs e 
retrovírus, apenas recentemente foram descritos sítios att em LTR-RTs (BENACHENHOU et al., 2013; SUONIEMI et al., 1997).

Ty3/Gypsy e Ty1/Copia são abundantes tanto em monocotiledônias quanto em eudicotiledônias (LLORENS et al., 2011; WICKER; KELLER, 2007). Dentre estas superfamílias, linhagens evolutivas foram amplamente identificadas. Cada uma dessas linhagens, dentro de cada superfamília, possui um ancestral comum e padrões distintos em termos de estrutura, regulação, expressão e distribuição cromossômica (DOMINGUES et al., 2012; WICKER; KELLER, 2007). Del, uma linhagem da superfamília Ty3/Gypsy, apresenta as maiores LTRs descritas até o momento, assim como o registro de maior variação de tamanho, onde os elementos mais compactos possuem LTRs de 1,1kb até as 4,4kb dos maiores elementos dessa linhagem (LLORENS et al., 2011). Elementos dessa linhagem são encontrados em todos os genomas vegetais examinados, sob vários nomes: Retrosat-2 em Oryza sativa, Tma e Legolas em Arabidopsis thaliana e Peabody em Pisum sativum (LLORENS et al., 2011). O presente capítulo visa aprofundar o conhecimento referente à variabilidade de tamanho, sequência e estrutura das LTRs e a identificação de sítios att na linhagem Del.

Grande parte do conhecimento sobre TEs (estrutura e regulação) deriva de organismos modelo, mas com o sequenciamento de diversos genomas vegetais nos últimos 10 anos é possível responder a perguntas mais complexas. A segunda fase do presente trabalho utiliza uma abordagem baseada na estrutura dos LRT-RTs e na criação de modelos "ocultos" de Markov (do inglês; Hidden Markov Models - HMM) para extrair e classificar cópias completas destes elementos de 10 genomas de angiospermas, completamente sequenciados. Os elementos da linhagem $\mathrm{Del}$, pertencentes à superfamília Gypsy, foram classificados em grupos de acordo com uma análise filogenética baseada em seus domínios codificantes. A estrutura de suas LTRs entre e intra grupos foi examinada com detalhes. Neste estudo foram identificados sítios att em todas as LTRs de cópias completas de todos os genomas estudados. Estes sítios obedecem a um padrão: duas variações na U5 e um único att conservado na U3. Neste trabalho também reportamos a presença de ilhas $\mathrm{CpG}$ (regiões ricas em citosina e guanina) nas LTRs, sendo que alguns grupos apresentaram uma ilha CpG a 5' dentro da LTR que é muito variável, tanto em tamanho quanto em conteúdo de sequência, quando comparada ao restante da sequencia da LTR. Para melhor compreender a dinâmica dos elementos da linhagem Del, nós também examinamos a distribuição desses elementos ao longo dos cromossomos de sorgo e milho. Elementos da linhagem Del são classificados como cromovírus (junto com Reina, CRM e Galadriel) por possuir um cromodomínio. Segundo a 
literatura, essa estrutura dirige a inserção destes elementos para regiões heterocromáticas do genoma (GAO et al., 2008; NOVIKOV et al., 2012). Como era esperado, os elementos da linhagem $\mathrm{Del}$ estudados se encontram concentrados em regiões pericentroméricas. Além da identificação de sítios att conservados em genomas distantes evolutivamente por 50-60 milhões de anos, descobrimos também uma distribuição desigual entre cromossomos de um mesmo genoma. Estes resultados compõem um manuscrito submetido à publicação intitulado "Virus-like attachment sites and plastic CpG islands: landmarks of diversity in plant Del retrotransposons".

\subsection{Materiais e métodos}

\subsubsection{Extração e classificação de elementos completos da linhagem Del}

O genoma de dez espécies vegetais (Arabidopsis thaliana, Medicago truncatula, Populus trichocarpa, Glycine max, Vitis vinifera, Setaria italica, Sorghum bicolor, Zea mays, Oriza sativa e Brachypodium distachyon) foram recuperadas em formato FASTA em 11/25/2011 do sítio WEB plantGDB (DUVICK et al., 2008). A sequência genômica foi organizada em cromossomos individuais para a subsequente análise pelo programa LTR_STRUC (MCCARTHY; MCDONALD, 2003) utilizando os parâmetros padrão. Perfis de Modelos ocultos de Markov (HMM) foram construídos através do pacote de ferramentas HMMER (versão 2.3.2) baseados no alinhamento em aminoácidos de transcriptase reversa de elementos previamente descritos no capítulo 1 desta tese (DOMINGUES et al., 2012). As sequências extraídas pelo LTR-STRUC foram traduzidas computacionalmente nos seis quadros de leitura possíveis e foram sujeitas a uma busca pela ferramenta HMMscan (pacote HMMER 2.3.2) contra os perfis de HMM, com um e-value de corte de $1 \mathrm{e}^{-10}$. Todas as sequências foram classificadas em linhagens (LLORENS et al., 2011 WICKER; KELLER, 2007;) de acordo com o melhor resultado desta busca. Um total de 47823 sequências foi recuperado pela estratégia utilizada, correspondentes a todos os LTR-RTs das duas superfamílias. Neste trabalho analisaremos as 2432 sequências classificadas como pertencentes à linhagem Del. 


\subsubsection{Análise filogenética}

As sequências classificadas como pertencentes à linhagem $\mathrm{Del}$ foram assinaladas a grupos através de uma abordagem filogenética, tendo como base a região codificante que compreende o domínio da transcriptase reversa e da RNAseH. As sequências nucleotídicas foram alinhadas através da ferramenta Kalign (LASSMANN; SONNHAMMER, 2005) e o alinhamento foi corrigido manualmente. O alinhamento final contém 2453 sequências (incluindo os grupos externos) e possui 2389 bases. O modelo ótimo para substituição de nucleotídeos foi estimado pela ferramenta MEGA5 (TAMURA et al., 2011b) utilizando os parâmetros padrão. A árvore filogenética foi construída seguindo o método de NeighborJoining, através do programa MEGA5 e utilizando o modelo de substituição sugerido pelo mesmo programa (Tamura 3-parâmetros com distribuição gama de 1,07) e um bootstrap de 500 réplicas. Sequências das linhagens Reina, CRM e Galadriel (DOMINGUES et al., 2012; LLORENS et al., 2011) foram utilizadas como grupos externos. Nove grandes ramos bem suportados se formaram e foram nomeados de Grupos I a IX. Dentro de cada grupo alguns ramos foram denominados Subgrupos a, b, etc.

\subsubsection{Identificando sítios att nas LTRs}

Os alinhamentos múltiplos foram analisados no programa Jalview (versão 2.4.0.b2) na opção em que o conjunto de sequências é identificada por conservação através de código de cores (WATERHOUSE et al., 2009). Os dez nucleotídeos que constituem o U3 att foram identificados ao analisar a conservação das primeiras 40 bases de um multifasta de todas as sequências não alinhadas. Em seguida foram extraídas as últimas 40 bases de cada sequência para encontrar a U5 att. Os primeiros e os últimos nucleotídeos não alinhados foram submetidos à geração de um WebLogo (http://weblogo.berkeley.edu) para gerar imagens que ilustrassem a conservação desta região em comparação ao resto do elemento. As sequências do sítio U5 att foram classificadas de acordo com a similaridade no Jalview (WATERHOUSE et al., 2009) e resultaram na organização de dois grupos. As sequências do sítio U3 att foram separadas por genoma. Todos os conjuntos de sítios att foram representados em imagens através do WebLogo. A media da distância $p$ foi calculada pelo programa MEGA 5 (TAMURA et al., 2011b), para quantificar a conservação dos sítios U3 e U5 de cada LTR. 


\subsubsection{Explorando características das LTRS}

O tamanho das LTRs foi extraído do arquivo resultante da análise pelo programa LTR_STRUC. A partir dos 34 subgrupos identificados com base na análise filogenética calculou-se a média de tamanho e o desvio padrão do tamanho das LTRs. Cada grupo foi tratado separadamente. O resultado foi utilizado para gerar gráficos de distribuição (um por genoma), onde cada ponto nesses gráficos representa uma cópia de um elemento da linhagem Del. Nesses gráficos as sequências formaram grupos de tamanho homogêneo, porém alguns pontos de tamanho discrepante se sobressaíram. 50 pontos extremamente discrepantes foram retirados do genoma de milho e suas sequências foram analisadas através de BLASTn (contra a própria sequência), para encontrar as extremidades de suas LTRs. Esta análise mostrou que LTRs de tamanho muito discrepante eram produto de um erro de extração do elemento causado pelo LTR_STRUC. Para as análises posteriores neste trabalho envolvendo tamanho de LTR, excluímos as sequências cujos pontos estavam a uma distância de três desvios padrões (para mais ou para menos) da média de tamanho daquele subgrupo.

Além do tamanho das LTRs, o tamanho do elemento completo também foi calculado com base nos resultados do LTR_STRUC. Para cada elemento, o tamanho da região intraLTRs (ou apenas "região interna") foi calculado através da subtração do tamanho das LTRs do tamanho do elemento completo. O estudo da variação de tamanho da LTR e do elemento completo foi realizado pela comparação de seus tamanhos em bases em gráfico linear. Comparamos da mesma forma o tamanho do elemento completo contra o tamanho da região interna.

Para caracterizar as ilhas CpG presentes nas LTRs, construímos alinhamentos com as sequências das LTRs de cada subgrupo. Em alguns casos, pudemos observar visualmente mais de um tipo de LTR presente no mesmo alinhamento. Essas foram então divididas em subgrupos e esses foram analisados separadamente. A sequências consenso de cada alinhamento foi submetida à ferramenta EMBOSS CpG island tool (LARSEN et al., 1992) para identificar possíveis ilhas $\mathrm{CpG}$ e calcular o conteúdo GC (\%GC). Para melhor compreender a variação/conservação destas ilhas $\mathrm{CpG}$, cada alinhamento foi submetido à ferramenta EMBOSS conservation plot tool (http://www.ebi.ac.uk/Tools/emboss/plotcon/), com seus parâmetros padrão. Os resultados dessas análises foram sobrepostos para cada alinhamento, reunindo em uma imagem conservação e porcentagem de GC à luz das ilhas CpG identificadas. 
Para determinar se as ilhas $\mathrm{CpG}$ eram mais variáveis em tamanho (ou mais “plásticas") do que o resto da LTR nós calculamos uma taxa de "plasticidade". Para tanto, nós isolamos as ilhas $\mathrm{CpG}$ presentes em cada alinhamento, ficando então com um alinhamento para cada ilha CpG e um para o "resto" da LTR. Após retirar os gaps, nós calculamos para cada arquivo o tamanho médio das sequências e o seu desvio padrão. O desvio padrão de cada arquivo foi então dividido por sua respectiva média de tamanho, resultando no número que representa sua variabilidade de tamanho, ou sua plasticidade.

\subsubsection{Distribuição de elementos Del nos cromossomos de milho e sorgo}

Dentre os arquivos que resultam em uma busca no programa LTR_STRUC encontramos a informação de qual cromossomo foi retirada cada cópia completa considerada neste estudo. A sequência consenso de 10 nucleotídeos na extremidade 5' foi usada para uma busca exata por palavras em um editor de texto contra o genoma de milho e sorgo sendo possível deste modo determinar o número de sítios U3 att. Tanto a fita positiva quanto a fita negativa foram consideradas neste estudo. Para validar a nossa metodologia, extraímos 3000 bases à jusante de cada sítio U3 att potencial encontrado no cromossomo 1 de milho. Essas sequências foram então submetidas à uma busca (BLASTn, cut-off e-value de $1 \mathrm{e}^{-10}$ ) contra cópias completas de elementos Del encontradas durante este trabalho. Para construir a figura que representa esse resultado, o número de U3 att encontrado foi normalizado, dividindo o número de hits pelo tamanho de cada cromossomo e multiplicando por $5 \times 10^{6}$, assim o histograma apresenta o número de cópias encontradas a cada cinco milhões de nucleotídeos $(5 \mathrm{Mb})$.

\subsection{Resultados}

\subsubsection{Encontrando elementos Del em dez genomas vegetais}

Dez genomas de angiospermas completamente sequenciados foram selecionados, sendo cinco monocotiledôneas (Setaria italica, Sorghum bicolor, Zea mays, O. sativa and Brachypodium distachyon) e cinco eudicotiledôneas (A. thaliana, Medicago truncatula, Populus trichocarpa, Glycine max e Vitis vinifera). Inicialmente, o programa LTR_STRUC foi usado para uma busca exaustiva de elementos completos em todos os 10 genomas. Desta busca, resultou um conjunto de 47823 cópias de LTR-RTs contendo duas LTRs intactas. 
Através de uma busca por HMMs foi possível classificar 2432 sequências como pertencentes à linhagem Del (Apendice 6). O LTR_STRUC ocasionalmente comete erros ao delimitar as extremidades das LTRs dos elementos encontrados. Duzentos e quarenta e cinco cópias foram excluídas do estudo por estarem mal delimitadas e conter LTRs incongruentes sendo o total de cópias reduzido para 2187 (APÊNDICE F).

\subsubsection{Análise filogenética da linhagem Del em plantas}

As sequências de elementos da linhagem $\mathrm{Del}$ foram assinaladas a grupos através de uma abordagem evolutiva, possibilitando identificar grupos com origem monofilética, a busca por características comuns ou específicas entre os elementos destes grupos e se estes grupos são compartilhados entre diferentes genomas. Nove grandes grupos foram identificados contendo em sua maioria elementos de mais de uma espécie. Estes foram numerados de I a IX como ilustrado na Figura 3.1. Todos os 9 grupos são monofiléticos e suportados por alto valor de bootstrap (>75), a exceção dos grupos I e III, que sendo monofiléticos, apresentam baixo valor de bootstrap suportando-os. Grupo IV é na verdade um subgrupo derivado do Grupo III, mas foi tratado separadamente por ser monofilético e possuir um alto valor de bootstrap na base de seu ramo. Grupos IV, VI e VIII são compostos por sequências de um único genoma cada: arroz, milho e sorgo, respectivamente. Todas as sequências de eudicotiledôneas se encontram no Grupo I, enquanto os outros oito grupos são compostos exclusivamente por sequências de elementos encontrados em monocotiledôneas. O Grupo II é o grupo mais próximo do grupo das eudicotiledôneas (Grupo I). Os grupos VII, VIII e IX fazem parte de um agrupamento maior denominado de Cluster $\mathrm{C}$, que se separa dos demais por um bootstrap de valor 99. Altos valores de bootstrap suportam a divisão destes grupos em subgrupos bem definidos, cada grupo com LTRs que compartilham semelhanças em tamanho, conteúdo de sequência e outras características conforme apresentado na Tabela 3.1. 


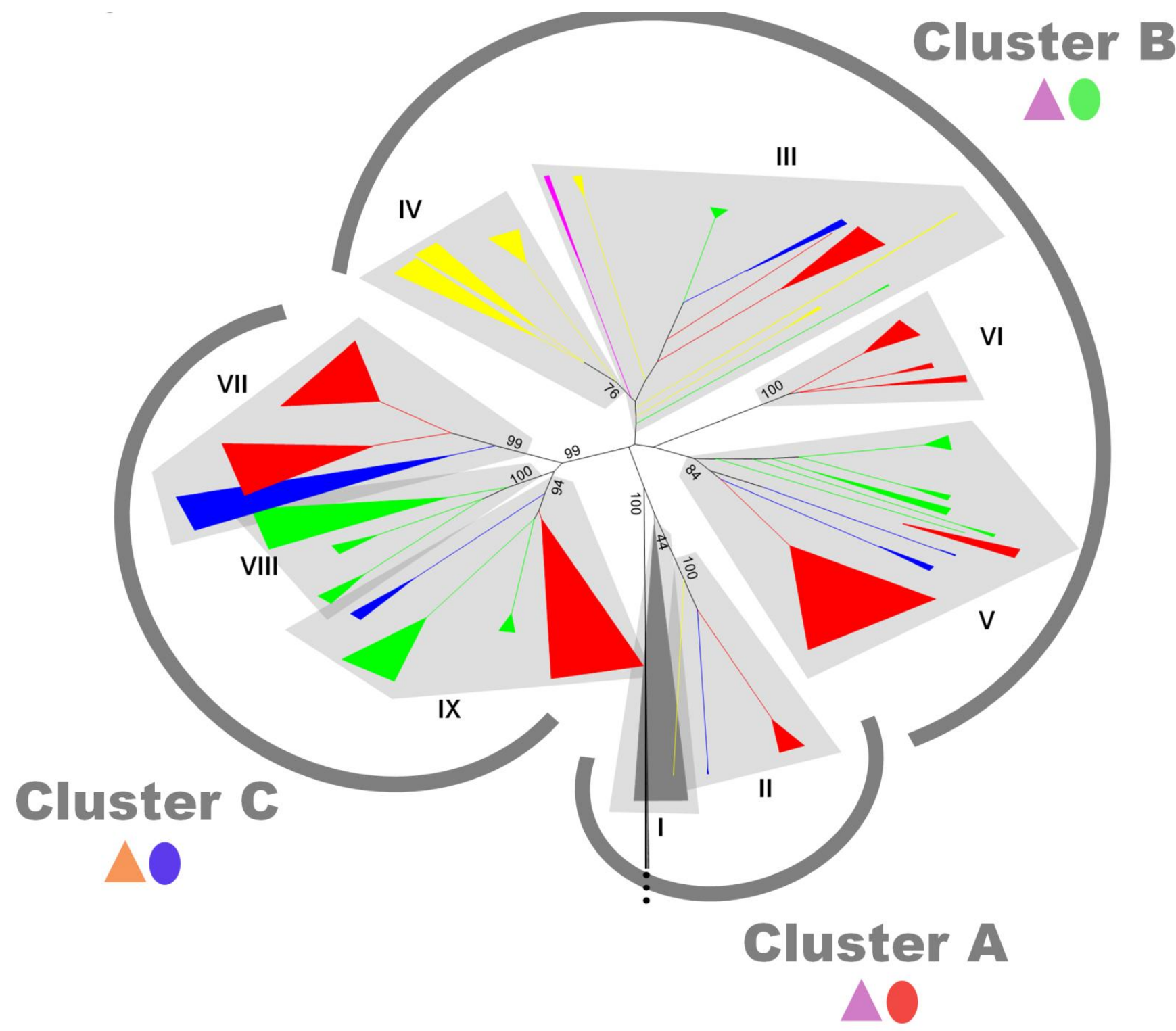

Figura 3.1 - Árvore filogenética da linhagem Del em plantas. A árvore filogenética foi gerada através da metodologia Neighbor-Joining pela ferramenta MEGA5 (TAMURA et al., 2011b) utilizando o modelo de substituição sugerido pela mesma ferramenta (Tamura 3-parâmetros com distribuição gama de 1,07) e um bootstrap 500 réplicas. A árvore foi baseada em um alinhamento de 2389 bp que envolve os domínios codificantes da RT e da RNAseH, com um total de 2453 sequências (incluindo os grupos externos). Sequência das linhagens Reina, CRM e Galadriel (LLORENS et al., 2011; DOMINGUES et al., 2012) foram utilizadas como grupos externos. Grupos identificados com alto valor de bootstrap foram nomeados com numerais romanos. Clusters que compartilham características de suas LTRs foram denominados A, B, e C. As cores indicam de que genoma se originam aquelas sequências, sendo: cinza = eudicotiledôneas $(A$. thaliana, $M$. truncatula, P. trichocarpa, G. max e V. vinifera), azul $=S$. italica, verde $=S$. bicolor, vermelho $=Z$. mays, amarelo $=O$. sativa e rosa $=B$. distachyon. triângulo roxo $=\mathrm{U} 5$ att tipo A; triângulo laranja $=\mathrm{U} 5$ att tipo $\mathrm{B}$; elipse vermelha $=$ padrão de ilha $\mathrm{CpG}$ na LTR do tipo $\mathrm{A}($ sem ilha $\mathrm{CpG})$; elipse verde $=$ padrão de ilha $\mathrm{CpG}$ na LTR do tipo B (uma ilha $\mathrm{CpG}$ ); elipse azul = padrão de ilha $\mathrm{CpG}$ na LTR do tipo $\mathrm{C}$ (duas ilhas $\mathrm{CpG}$ ). Mais detalhes sobre os tipos de att serão apresentados no APÊNDICE G. Mais detalhes dos tipos de ilha CpG serão explorados na Figura 3.5. Subgrupos estão listados na Tabela 3.1. Grupos externos estão representados nesta figura como a linha preta com três pontos. 
Tabela 3.1 - Resumo das características exploradas nos retrotranspososns da linhagem Del, por grupo e subgrupo. As diferentes cores de realce indicam clusters diferentes, definidos por características presentes nas LTRs de suas sequências.

\begin{tabular}{|c|c|c|c|c|c|c|c|c|c|c|c|}
\hline \multirow[t]{2}{*}{ Grupo } & \multirow[t]{2}{*}{ Subgrupo } & \multirow[t]{2}{*}{$\begin{array}{l}\mathrm{N}^{\circ} \text { total de } \\
\text { sequências }\end{array}$} & \multirow[t]{2}{*}{$\begin{array}{l}\mathrm{N}^{\circ} \text { final de } \\
\text { sequencias }\end{array}$} & \multirow[t]{2}{*}{ Genoma } & \multicolumn{2}{|c|}{$\begin{array}{c}\text { Ilha CpG } \\
\checkmark=\text { presente } \\
\boldsymbol{x}=\text { ausente }\end{array}$} & \multirow[t]{2}{*}{$\begin{array}{l}\text { Tipo de } \\
\text { U5 att }\end{array}$} & \multirow{2}{*}{$\begin{array}{l}\text { Tamanho médio } \\
\text { da LTR em pb } \\
\text { (desvio padrão) }\end{array}$} & \multicolumn{2}{|c|}{$\begin{array}{l}\text { \% Identidade } \\
\text { nucleotídica }\end{array}$} & \multirow[t]{2}{*}{ Bootstrap } \\
\hline & & & & & $5^{\prime}$ & $3^{\prime}$ & & & $\begin{array}{l}\text { Ilha } \\
\text { CpG 5' }\end{array}$ & $\begin{array}{l}\text { Resto } \\
\text { da LTR }\end{array}$ & \\
\hline \multirow{5}{*}{ I } & $\mathrm{a}$ & 11 & 10 & At & $x$ & $x$ & A & $1190.4(75.3)$ & - & $*$ & 100 \\
\hline & $\mathrm{b}$ & 17 & 16 & $\mathrm{Vv} / \mathrm{Pt}$ & $x$ & $x$ & A & $2187.3(81.5)$ & - & $*$ & 88 \\
\hline & $\mathrm{c}$ & 10 & 6 & $\mathrm{Gm}$ & $x$ & $x$ & A & $2397.3(30.4)$ & - & 93.3 & 100 \\
\hline & d & 23 & 19 & $\mathrm{Gm}$ & $x$ & $x$ & A & $3737.1(169.8)$ & - & 85.1 & 100 \\
\hline & $\mathrm{e}$ & 57 & 43 & Mt & $x$ & $x$ & $\mathrm{~A}$ & $2131.4(34.2)$ & - & $*$ & 100 \\
\hline \multirow{3}{*}{ II } & $\mathrm{a}$ & 1 & 1 & Os & $x$ & $x$ & A & $2113.0(-)$ & - & - & - \\
\hline & $\mathrm{b}$ & 3 & 3 & $\mathrm{Si}$ & $x$ & $x$ & A & $2162.7(2.3)$ & - & 56.1 & 100 \\
\hline & $\mathrm{c}$ & 60 & 53 & $\mathrm{Zm}$ & $x$ & $x$ & $\mathrm{~A}$ & $2381.1(100.9)$ & - & 52.9 & 100 \\
\hline \multirow{9}{*}{ III } & $\mathrm{a}$ & 11 & 8 & $\mathrm{Bd}$ & $\checkmark$ & $x$ & A & $3251.8(77.6)$ & 51.0 & 74.8 & 100 \\
\hline & $\mathrm{b}$ & 20 & 20 & Os & $\checkmark$ & $\checkmark$ & A & $3875.8(97.8)$ & 76.4 & 93.0 & 100 \\
\hline & $\mathrm{c}$ & 39 & 33 & $\mathrm{Sb}$ & $\checkmark$ & $x$ & A & $2652.9(138.8)$ & 74.2 & 92.9 & 100 \\
\hline & d & 20 & 16 & $\mathrm{Si}$ & $\checkmark$ & $x$ & A & $2819.0(150.1)$ & 42.3 & 80.8 & 100 \\
\hline & $\mathrm{e}$ & 1 & 1 & $\mathrm{Zm}$ & $\checkmark$ & $x$ & A & $2915.0(-)$ & - & - & - \\
\hline & $\mathrm{f}$ & 87 & 83 & $\mathrm{Zm}$ & $\checkmark$ & $x$ & A & $2823.8(35.6)$ & 63.4 & 80.6 & 100 \\
\hline & $\mathrm{g}$ & 1 & 1 & Os & $\checkmark$ & $x$ & A & $4235.0(-)$ & - & - & 87 \\
\hline & $\mathrm{h}$ & 8 & 7 & Os & $\checkmark$ & $\checkmark$ & A & $3861.6(112.4)$ & 51.9 & 84.0 & 100 \\
\hline & $\mathrm{i}$ & 4 & 4 & $\mathrm{Sb}$ & $\checkmark$ & $\checkmark$ & A & $3946.8(18.2)$ & 61.0 & 89.6 & 100 \\
\hline \multirow{3}{*}{ IV } & $\mathrm{a}$ & 72 & 68 & Os & $\checkmark$ & $\checkmark$ & A & 3094.7 (166.9) & 57.3 & 79.6 & 100 \\
\hline & $\mathrm{b}$ & 63 & 63 & Os & $\checkmark$ & $x$ & A & $2953.1(79.3)$ & 69.9 & 83.8 & 100 \\
\hline & $\mathrm{c}$ & 75 & 67 & Os & $\checkmark$ & $x$ & A & $3152.1(9.9)$ & 85.7 & 93.2 & 100 \\
\hline \multirow{9}{*}{$\mathrm{V}$} & $\mathrm{a}$ & 51 & 48 & $\mathrm{Sb}$ & $\checkmark$ & $\checkmark$ & A & $2719.6(95.4)$ & 43.0 & 81.1 & 100 \\
\hline & $\mathrm{b}$ & 19 & 14 & $\mathrm{Sb}$ & $\checkmark$ & $x$ & A & $2846.6(38.4)$ & 71.5 & 92.1 & 100 \\
\hline & $\mathrm{c}$ & 25 & 22 & $\mathrm{Sb}$ & $\checkmark$ & $x$ & A & $2926.0(51.1)$ & 56.9 & 78.7 & 98 \\
\hline & d & 10 & 9 & $\mathrm{Sb}$ & $\checkmark$ & $\checkmark$ & A & $3186.2(10.4)$ & 87.1 & 93.3 & 100 \\
\hline & $\mathrm{e}$ & 1 & 1 & $\mathrm{Sb}$ & $\checkmark$ & $x$ & A & $3292.0(-)$ & - & - & 100 \\
\hline & $\mathrm{f}$ & 32 & 27 & $\mathrm{Zm}$ & $\checkmark$ & $x$ & A & 3400.9 (122.7) & 36.7 & 77.0 & 100 \\
\hline & $\mathrm{g}$ & 3 & 2 & $\mathrm{Si}$ & $\checkmark$ & $\checkmark$ & A & $2821.0(62.2)$ & 87.2 & 85.5 & 100 \\
\hline & $\mathrm{h}$ & 17 & 17 & $\mathrm{Si}$ & $\checkmark$ & $x$ & A & $2803.0(77.7)$ & 61.4 & 90.9 & 100 \\
\hline & $\mathrm{i}$ & 337 & 318 & $\mathrm{Zm}$ & $\checkmark$ & $x$ & $\mathrm{~A}$ & $3323.1(106.3)$ & 29.9 & 69.9 & 100 \\
\hline \multirow{3}{*}{ VI } & $\mathrm{a}$ & 70 & 60 & $\mathrm{Zm}$ & $\checkmark$ & $x$ & A & 2718.4 (203.6) & 47.6 & 82.2 & 100 \\
\hline & $\mathrm{b}$ & 17 & 14 & $\mathrm{Zm}$ & $\checkmark$ & $x$ & A & $3571.6(96.8)$ & 56.8 & 75.6 & 100 \\
\hline & $\mathrm{c}$ & 24 & 16 & $\mathrm{Zm}$ & $\checkmark$ & $x$ & A & $3687.2(79.1)$ & 54.3 & 81.8 & 100 \\
\hline \multirow{3}{*}{ VII } & $\mathrm{a}$ & 126 & 110 & $\mathrm{Si}$ & $\checkmark$ & $\checkmark$ & B & $3165.1(30.6)$ & 77.6 & 82.0 & 98 \\
\hline & $\mathrm{b}$ & 191 & 173 & $\mathrm{Zm}$ & $\checkmark$ & $\checkmark$ & B & $4670.5(34.9)$ & 78.4 & 86.8 & 100 \\
\hline & $\mathrm{c}$ & 287 & 264 & $\mathrm{Zm}$ & $\checkmark$ & $\checkmark$ & $\mathrm{B}$ & $4347.8(34.2)$ & 72.1 & 79.8 & 96 \\
\hline \multirow{3}{*}{ VIII } & a & 41 & 35 & $\mathrm{Sb}$ & $\checkmark$ & $\checkmark$ & B & $4498.9(23.2)$ & 74.7 & 88.4 & 100 \\
\hline & $\mathrm{b}$ & 34 & 29 & $\mathrm{Sb}$ & $\checkmark$ & $\checkmark$ & B & $4559.1(61.2)$ & 74.3 & 87.7 & 100 \\
\hline & $\mathrm{c}$ & 147 & 141 & $\mathrm{Sb}$ & $\checkmark$ & $\checkmark$ & $\mathrm{B}$ & $3941.3(31.0)$ & 62.6 & 88.7 & 98 \\
\hline \multirow{4}{*}{ IX } & $\mathrm{a}$ & 209 & 167 & $\mathrm{Zm}$ & $\checkmark$ & $\checkmark$ & B & $4025.3(24.3)$ & 46.5 & 72.9 & 56 \\
\hline & $\mathrm{b}$ & 36 & 36 & $\mathrm{Sb}$ & $\checkmark$ & $\checkmark$ & B & $3935.7(94.3)$ & 54.5 & 89.4 & 100 \\
\hline & $\mathrm{c}$ & 141 & 131 & $\mathrm{Sb}$ & $\checkmark$ & $\checkmark$ & B & $4160.3(100.6)$ & 53.1 & 89.2 & 100 \\
\hline & $\mathrm{d}$ & 31 & 31 & $\mathrm{Si}$ & $\checkmark$ & $x$ & $\mathrm{~B}$ & 4076.7 (41.8) & 70.3 & 83.7 & 100 \\
\hline
\end{tabular}




\subsubsection{Descobrindo os sítios att em LTR-RTs da linhagem Del presente nos 10 genomas.}

Duas pequenas regiões conservadas foram encontradas nas duas extremidades dos LTR-RTs, na mesma posição em que são encontrados os sítios att nos retrovírus (MASUDA et al., 1998). A região encontrada na extremidade 5' do elemento, na U3 da LTR, nós chamamos de U3 attachment site (U3 att). A visualização do alinhamento múltiplo das 2187 cópias completas extraídas dos 10 genomas foi possível observar a existência da conservação de sequências nas extremidades. Essas possuem 10 pares de bases e 11 pares de bases conservadas respectivamente a 5' e a 3' do elemento como pode ser visualizado na figura 3.2. Considerando a orientação do quadro de leitura do elemento e a organização das LTRs conforme apresentado na figura 3.2, propomos chamar o sítio att localizado na U3 da extremidade 5' do elemento de sítio U3 att e o sítio localizado na U5 de U5 att. O sítio U3 att apresenta uma identidade média de 72,2\% enquanto o sítio U5 att apresenta uma identidade média de 61,9\%. Ao examinar detalhadamente o sítio U3 att em todos os genomas, descobrimos que além de um dinucleotídeo bastante conservado (TG/CA), os nucleotídeos nas posições 3, 6, 9 e 10 são os mais conservados (Figura 3.3). A mesma análise realizada no sítio U5 att aponta que as posições mais conservadas são -1, -2, -3 e -6. Dois tipos de sítios U5 att foram identificados, através de diferenças nas bases de posição -8, -9 e -10. As sequências dos grupos I a VI na árvore filogenética (Cluster A e B) possuem um U5 att do tipo A, com GGG nessas posições, enquanto os grupos VII, VIII e IX (cluster C) possuem um U5 att do tipo B com os nucleotídeos TTC nessas posições (APÊNDICE G).

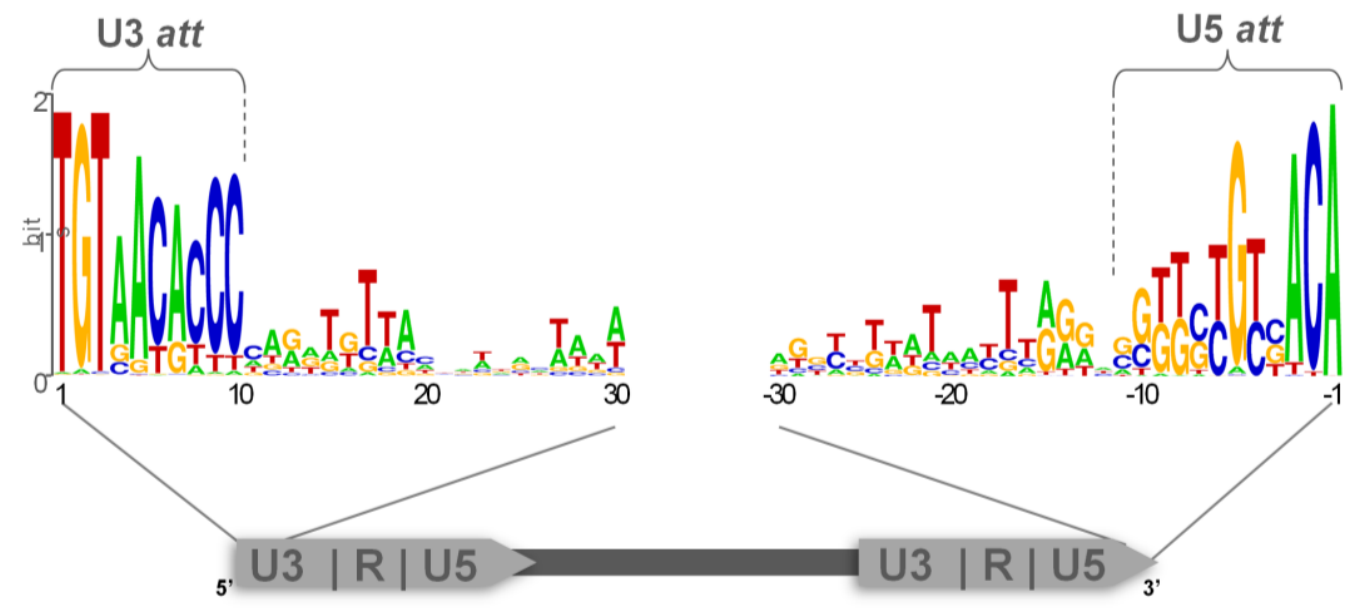

Figura 3.2 - Conservação nos sítios U3 e U5 att de todos os elementos da linhagem Del. Na parte de baixo da figura é possível observar a representação gráfica de um LTR-RT, com as regiões U3, R e U5 em suas LTRs. Os logos de conservação dos primeiros e últimos 40 nucleotídeos dos elementos da linhagem Del estão representados na parte superior da figura. O sítio U5 att pode ser dividido em dois grupos (APÊNDICE G), 
enquanto o sítio U3 att é conservado entre todos os genomas estudados (Figura 3.3). As linhas apontam a região onde os sítios att se encontram nos LTR-RTs. Um logo de conservação é uma representação gráfica de um alinhamento múltiplo. Cada logo consiste em pilhas verticalizadas de símbolos, sendo cada pilha uma posição do alinhamento. A altura de cada pilha indica a conservação daquela posição, enquanto a altura de cada símbolo representa a frequência relativa daquele nucleotídeo naquela posição.
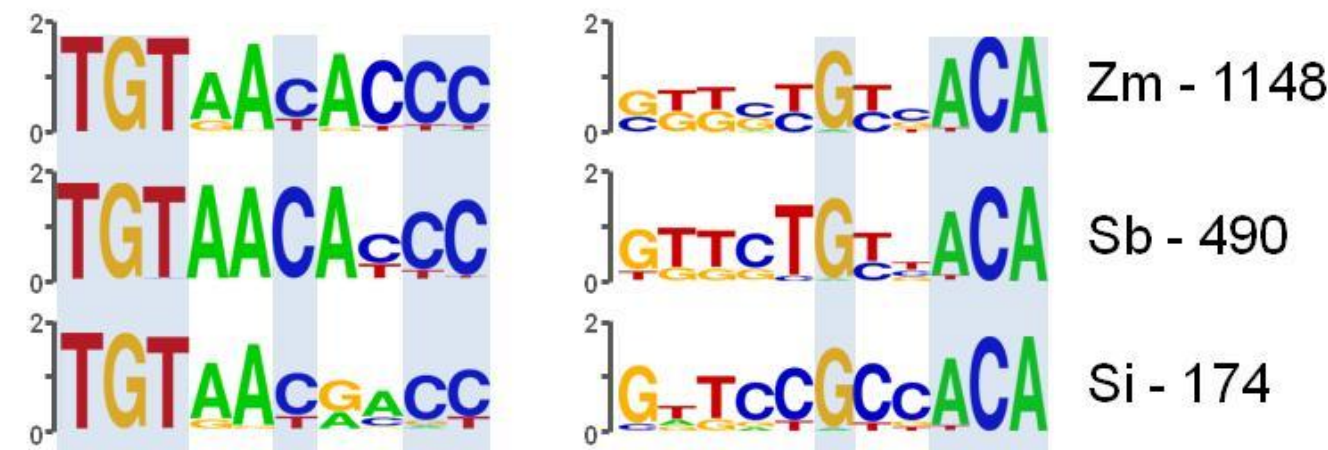
$\left.{ }_{0}^{2}\right] \mathrm{GTTCIGI.AG/N} \mathrm{Sb-490}$ $\left.{ }_{0}^{2}\right]$ TCC CCACA Si - 174
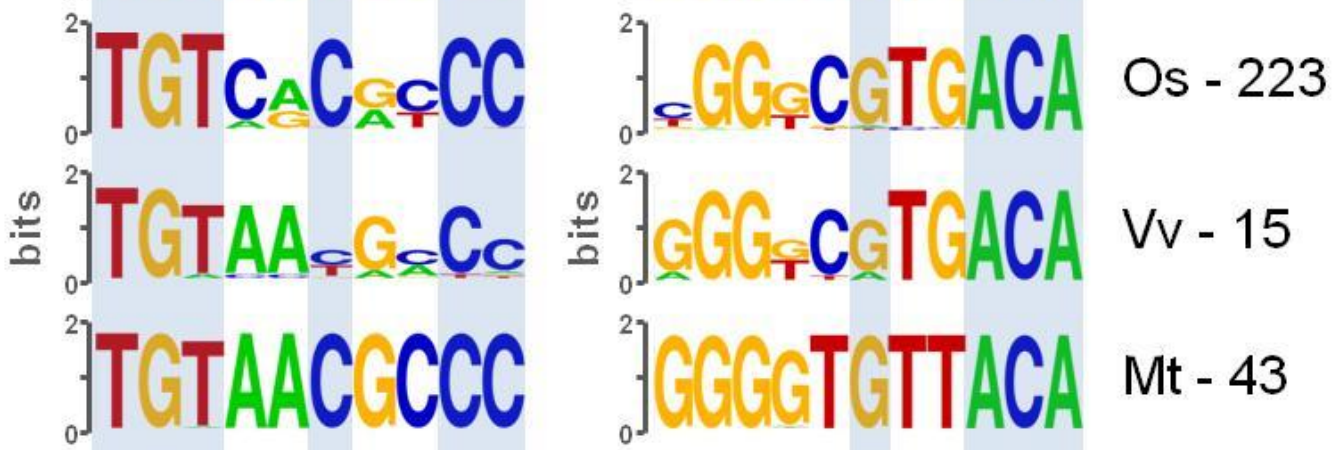

Mt - 43
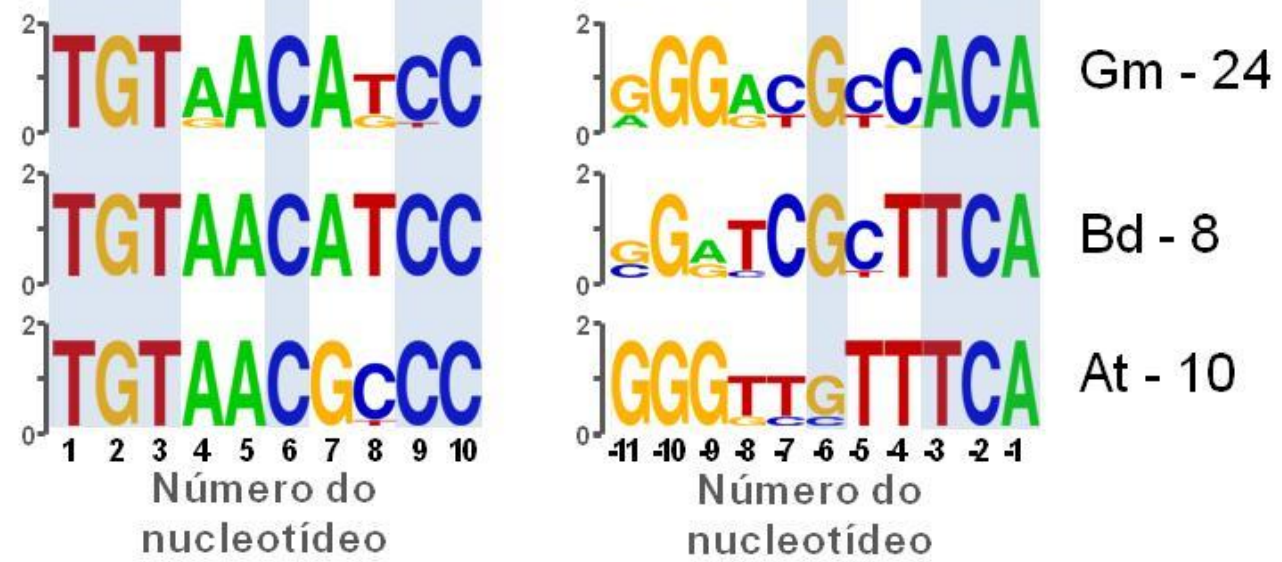

Figura 3.3 - Conservação nos sítios U3 att por genoma. A conservação do provável sítio U3 att dentre os genomas: $\mathrm{Zm}=Z$. mays, $\mathrm{Sb}=S$. bicolor, $\mathrm{Si}=S$. italica, $\mathrm{Os}=O$. sativa, $\mathrm{Vv}=V$. vinifera $; \mathrm{Mt}=M$. truncatula; $\mathrm{Gm}=G$. max $; \mathrm{Bd}=B$. distachyon, $A t=A$. thaliana. $P$. trichocarpa não está na figura, pois apresentou apenas uma sequência. As barras azuis indicam as bases mais conservadas. A descrição de um logo de conservação de sequência foi feita na Figura 3.2. 


\subsubsection{Explorando as LTRs}

Analisamos as variações no tamanho das LTRs dos elementos da linhagem Del e a correlação dessas variações com a presença de ilhas $\mathrm{CpG}$ nessas estruturas, que são conhecidas por conter a região regulatória dos LTR-RTs. As ilhas CpG nos chamaram a atenção por dois motivos, pelametilação de sítios $\mathrm{CpG}$ no promotor de genes pode levar ao silenciamento desse gene; e pela metilação das LTRs de um retrotransposon geralmente está associada como uma maneira do genoma hospedeiro de inibir a atividade transcricional do mesmo.

A variação do tamanho das LTRs é bem aparente quando analisados os extremos, neste trabalho a menor LTR de um elemento da linhagem Del encontrada foi em Arabidopsis, uma sequência com 1143pb, enquanto a maior foi em milho, com 4831bp (Tabela 3.1). Nós comparamos o tamanho das LTRs encontradas com o tamanho da região interna e do elemento completo. Nós também comparamos o tamanho da região interna com o do elemento completo. A única correlação consistente encontrada foi entre o tamanho da LTR e o tamanho do elemento completo $\left(\mathrm{R}^{2}=0.92141\right)$ (Figura 3.4).

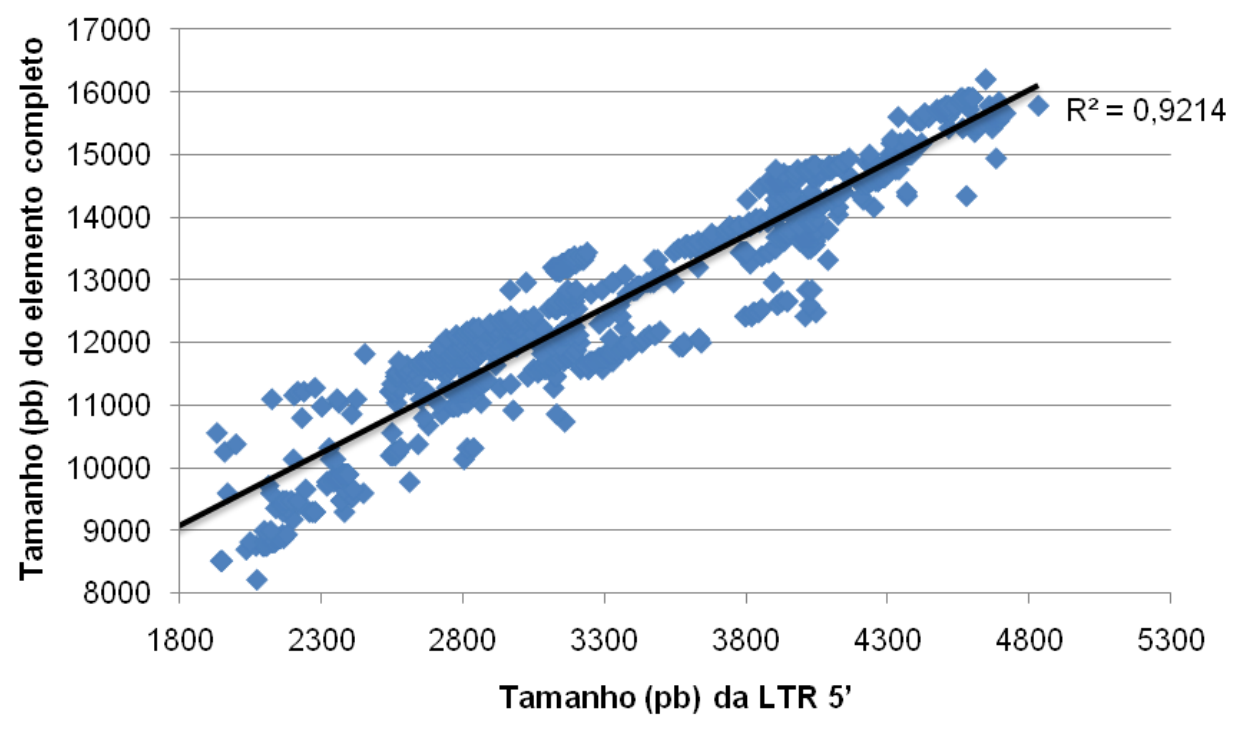

Figura 3.4 - Correlação entre o tamanho da LTR e o tamanho do elemento completo. Os tamanhos das LTRs e dos elementos completos foram encontrados pelo programa LTR_STRUC. O coeficiente de determinação $\left(\mathrm{R}^{2}\right)$ foi calculado através do Microsoft Excel, este aponta uma significativa correlação positiva entre o tamanho da LTR e do elemento completo $\left(\mathrm{R}^{2}=0.92141\right)$.

Duas ilhas CpG foram identificadas, uma mais à montante (5') da LTR e outra mais à jusante (3') da LTR (Figura 3.5). A presença ou ausência destas ilhas se sobrepuseram aos grupos analisados, de forma que encontramos três padrões principais: grupos sem ilhas $\mathrm{CpG}$ em suas LTRs (Cluster A), grupos que possuem apenas a ilha CpG à 5' da LTR (Cluster B) e 
os grupos que possuem ambas as ilhas CpG 5' e 3' (Cluster C) (Figura 3.1 e 3.5). A ilha CpG presente na 5' da LTR mostrou-se frequentemente associada com uma baixa conservação de sequência e foi encontrada em todos os grupos, exceto I e II. A ilha CpG presente na 3' da LTR mostrou-se associada à uma alta conservação nucleotídica e foi encontrada consistentemente nos elementos dos grupos VII, VIII e IX (Tabela 3.1). A ilha CpG presente na 5' da LTR não está associada à variação apenas a nível de conteúdo de sequência, mas também de tamanho. Para quantificar essa variação de tamanho, nós comparamos o tamanho dessa ilha ao tamanho do resto da LTR. Observamos que a ilha CpG presente na 5' da LTR é geralmente a região mais plástica da LTR (Figura 3.6).

A

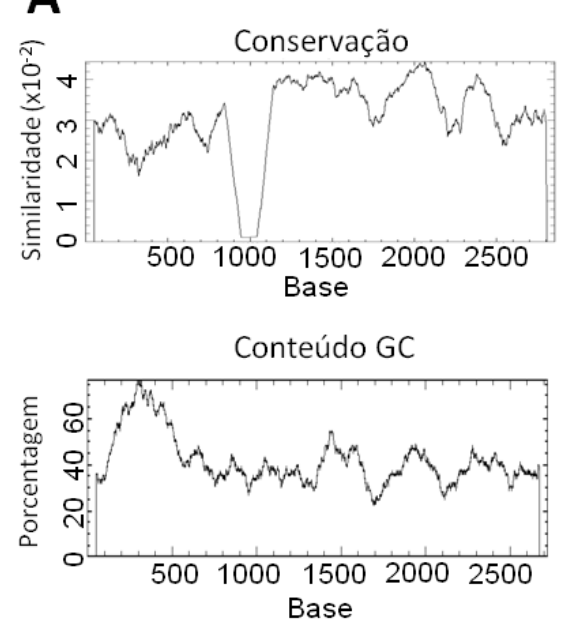

B

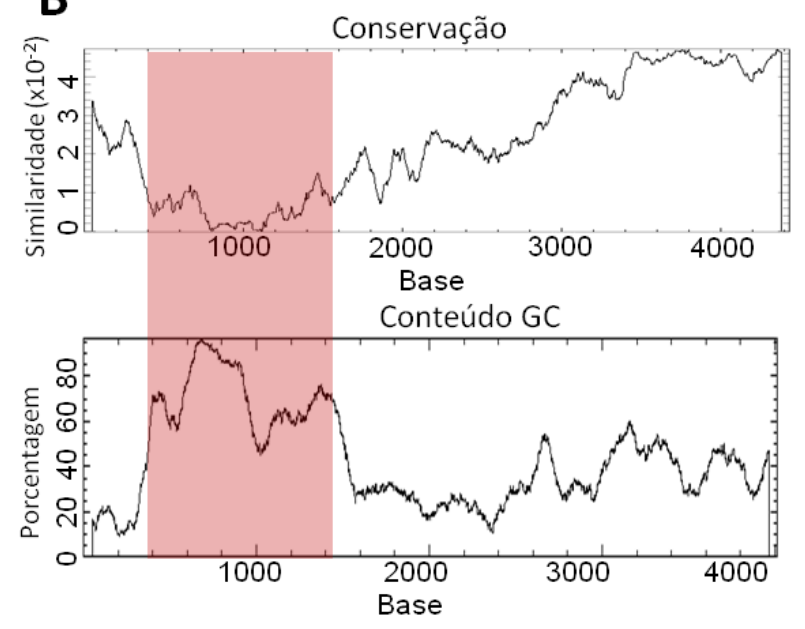

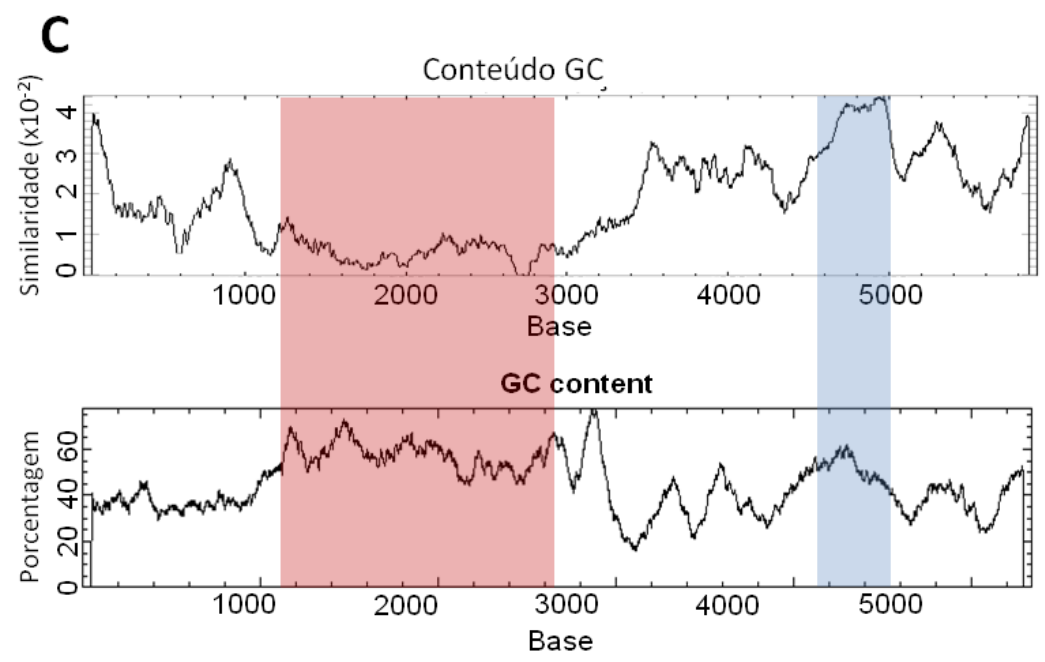

Figura 3.5 - Exemplos dos três tipos de padrões de ilha CpG encontrados nas LTRs. Os gráficos mostram a conservação (gráficos superior) e a porcentagem de GC (gráficos inferiores) nas LTRs. As ilhas CpG identificadas pelo programa $\mathrm{CpG}$ plot estão indicadas pelas barras verticais vermelha (ilha $\mathrm{CpG}$ na 5 ' da LTR) e azul (ilha CpG na 3' da LTR). (A) Padrão sem ilhas CpG identificadas (exemplo é do grupo 1C da Figura 1); (B) padrão onde uma ilha CpG é encontrada na metade 5' da LTR (exemplo é do grupo 5F na Figura 1) e (C) padrão onde duas ilhas $\mathrm{CpG}$ foram identificadas, uma na região 5' e outra na região 3' da LTR (exemplo é do grupo 9A da Figura 2). 


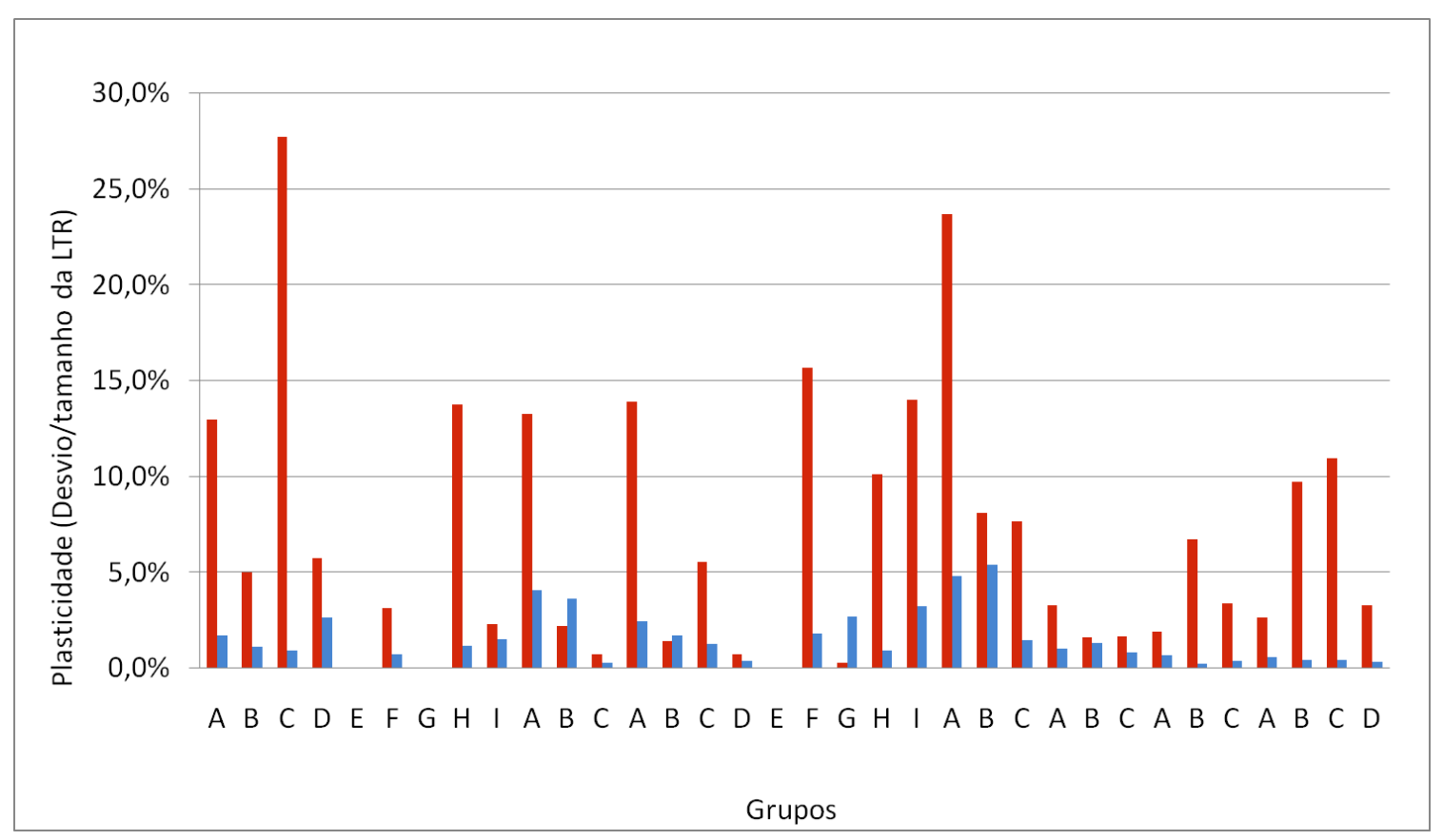

Figura 3.6 - Comparação da variação do tamanho da ilha CpG na região 5' da LTR com a variação no tamanho do resto da LTR. A "plasticidade" das LTR foi calculada para cada grupo e subgrupo observados na análise filogenética. Duas regiões foram comparadas, a ilha CpG presente na região 5' da LTR e o resto da LTR. Para cada região o desvio padrão do tamanho foi dividido pela média de tamanho, para cada subgrupo. Barras vermelhas representam a plasticidade das ilhas $\mathrm{CpG}$ enquanto as barras azuis representam a plasticidade do resto da LTR. Os grupo 1 e 2 não aparecem na figura pois não apresentam ilha CpG em suas LTRs.

\subsubsection{Distribuição de elementos da linhagem Del por cromossomo de sorgo e milho}

Para verificar se os elementos da linhagem Del estavam homogeneamente dispersos entre os diferentes cromossomos de milho e sorgo, nós calculamos a frequência de cópias completas e do U3 att por cada 5Mb nos cromossomos de milho e sorgo, os genomas com o maior número de cópias encontradas (548 e 1315, respectivamente). Buscando validar nosso método, de usar U3 atts para identificar elementos Del, descobrimos que $81.3 \%$ dos hits de att de Sorgo e $78.2 \%$ dos hits de milho estão associados à uma LTR de um elemento Del. A sequência que melhor representa o U3 att (TGTAACACCC, encontrado em 49.4\% das cópias de sorgo e $40.7 \%$ das cópias de milho encontrado pelo LTR_SCTRUC) mostraram-se uniformemente distribuídos pelos cromossomos de milho (Figura 3.7). Entretanto, cópias completas dos elementos, nos dois genomas, e U3 att, em sorgo, não possuem uma distribuição homogênea. Essa observação é particularmente evidente nos cromossomos 6 e 7 de milho e nos cromossomo 1 de sorgo. Nos cromossomos 6 e 7 de milho menos de uma cópia completa foi encontrada por cada $5 \mathrm{Mb}$, na média, enquanto o número de sítios U3 att é similar ao encontrado nos outros cromossomos (aproximadamente três por $5 \mathrm{Mb}$ ). O cromossomo 1 de sorgo não apenas apresentou um número de cópias completas menor, em 
relação aos outros cromossomos, como também menos sítios U3 att foram encontrados nesse cromossomo. A distribuição de U3 att e cópias completas (Figura 3.8) indica que estes elementos são geralmente pericentroméricos em sorgo e milho, consistente com a literatura (PATERSON et al., 2009; BAUCOM et al., 2009).
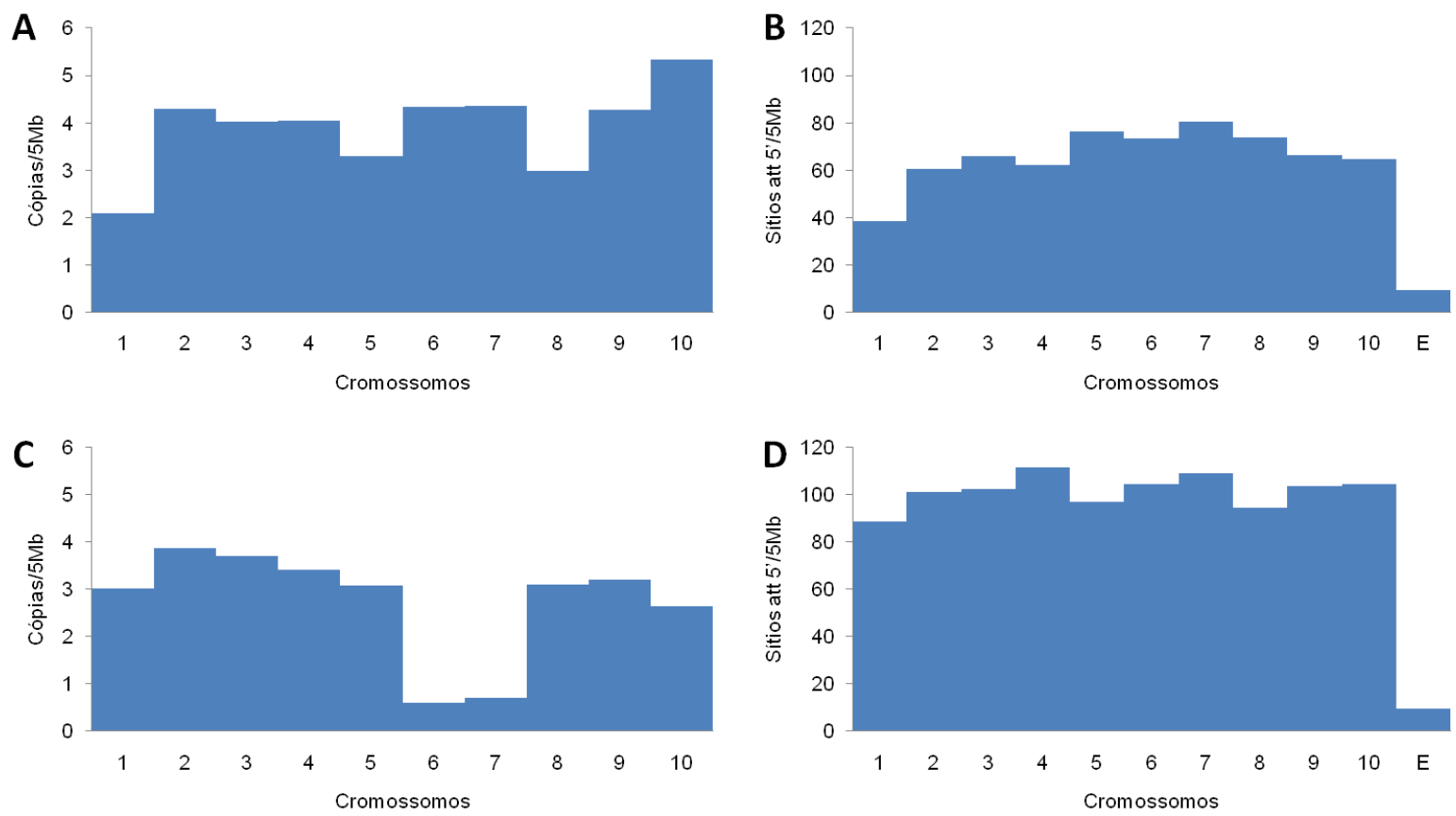

Figura 3.7 - Número total de elementos completos e U3 att encontrados por $5 \mathrm{Mb}$ para cada genoma de sorgo (A e B) e milho (C e D). O número de cópias completas foi calculado a partir do resultado do LTR_STRUC e dividido normalizado considerando o tamanho de cada cromossomo (A e C). O número de U3 att (B e D) foi estimado através da busca pela palavra consenso (TGTAACACCC) nos cromossomos e normalizado de acordo com o tamanho desses. A letra $\mathrm{E}$, nos gráficos B e D é a frequência esperada de uma sequência de dez nucleotídeos aparecer ao acaso (uma em $4^{10}$ nucleotídeos). 


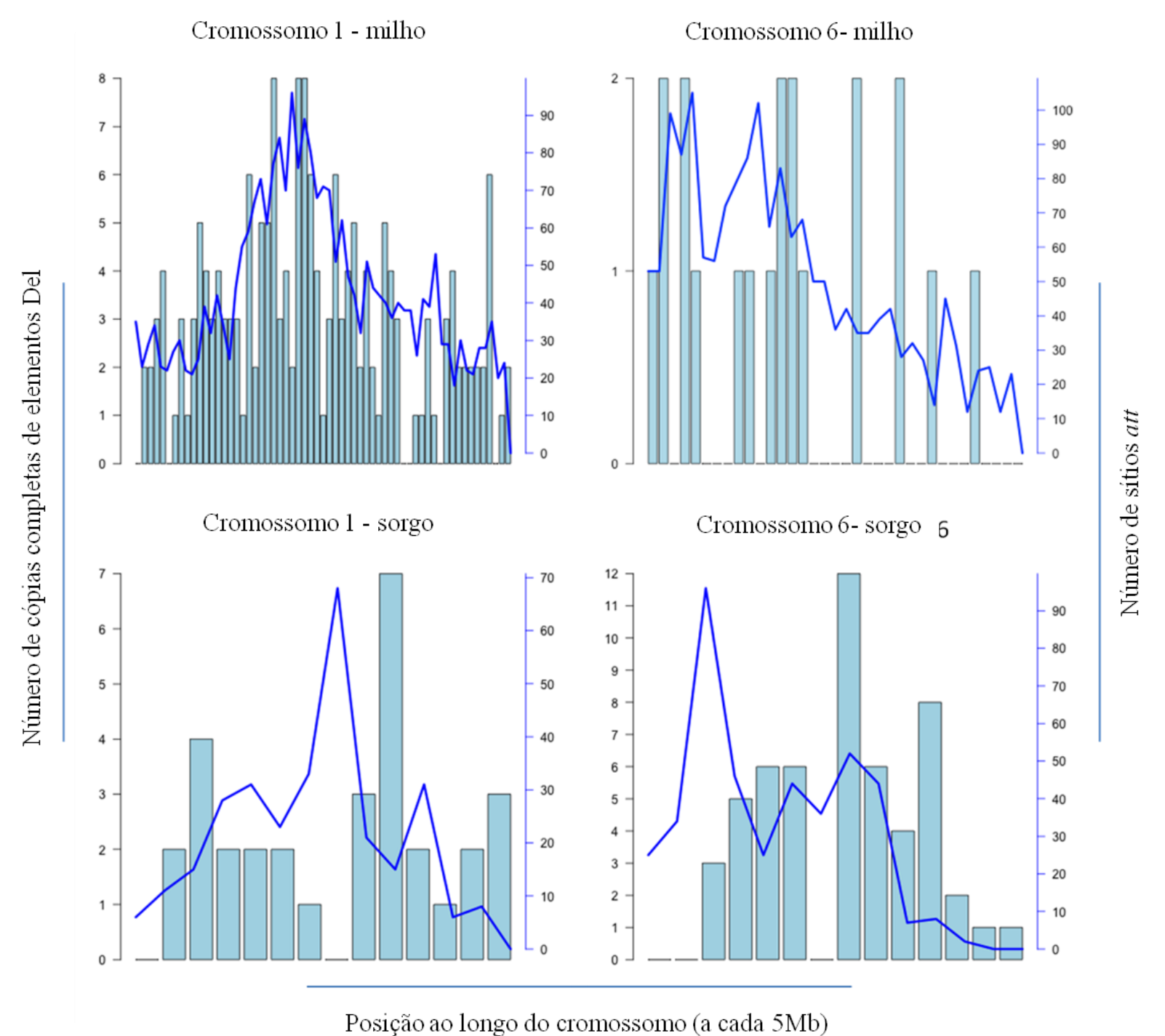

Figura 3.8 - Distribuição dos U3 att e cópias completas de Del ao longo dos cromossomos 1 e 6 de sorgo e milho. U3 att encontrados estão representados pela linha azul escura. Barras azuis representam as cópias completas encontradas a cada $5 \mathrm{Mb}$.

\subsection{Discussão}

Grande parte do genoma das plantas é composta por LTR-RTs, e estes já mostraram ser impactantes para a evolução dos genomas (VITTE; PANAUD, 2005). Ao longo deste trabalho nós exploramos elementos Del de 10 genomas de plantas, para examinar a diversidade de suas LTRs e sua variabilidade de conteúdo de sequência e tamanho, sob um olhar filogenético. Elementos da linhagem $\mathrm{Del}$ possuem as maiores LTR já descritas e são encontrados em abundância nos genomas vegetais sequenciados (LLORENS et al., 2011). Nossos resultados sugerem que as LTRs possuem um papel importante na especificidade da integração de novas cópias. 


\subsubsection{Sítios att identificados e conservados para todas as cópias completas de Del}

Attachment (att) sites foram previamente descritos em retrovírus como uma região de 8 a 12 nucleotídeos, encontradas nas extremidades do elemento, que são as únicas regiões virais necessárias para o reconhecimento da maquinaria de integração (MASUDA et al., 1998; KANG et al., 2008). Estudos in vitro mostraram que a integrase interage com o sítio att para mediar a integração (CHIU; GRANDGENETT, 2000), assim como foi demonstrado que a integrase reconhece independentemente os U3 e U5 att para formar o complexo sináptico (MASUDA et al., 1998; BERA et al., 2009). Como reportado anteriormente, apenas alguns nucleotídeos do sítio att, denominados sítios de interação, são necessários para conferir especificidade durante a interação com a integrase (CHIU; GRANDGENETT, 2000; MASUDA et al., 1998; KANG et al., 2008). Outros estudos demonstraram que mutações pontuais nesses sítios att reduzem ou eliminam a capacidade da integrase de reconhecer as LTRs, inibindo a transposição da cópia estudada ( BROWN et al., 1999; MASUDA et al., 1998).

Até a presente data, sítios att foram estudados sem grande ênfase em LTR-RTs. Um total de 2187 cópias, com duas LTRs, foram examinadas na busca por sítios conservados. Identificamos que na linhagem $\mathrm{Del}$, os primeiros 10 e os últimos 11 nucleotídeos são bastante conservados, não importando o genoma de origem (Figura 3.2 e Tabela 3.1). A conservação dessas bases em mais de duas mil sequências nos leva a crer que essas possuem um papel central no ciclo de vida desses retrotransposons.

Como comentamos o U3 att é bastante conservado, com $72.2 \%$ de identidade, ao passo que o U5 att mostrou-se menos conservado com $61.9 \%$ de identidade ao longo de todas as sequências estudadas. Nós identificamos alguns nucleotídeos mais conservados em ambos U3 e U5 att, que acreditamos serem candidatos a sítios de interação com a integrase. Observamos que as sequências de U5 att eram compostas por dois tipos de sequência, que foram divididas em dois grupos (tipo A e tipo B), o que explica a identidade menor das sequências do U5 att em comparação ao U3 att (Figura 3.2 e APÊNDICE G). Surpreendentemente, os dois tipos de U5 att não estavam disperses na árvore filogenética aleatoriamente. Encontramos os U5 att do tipo B apenas nas sequências dos Grupos VII a IX (Cluster C). Já o U5 att do tipo A parece ser o tipo mais ancestral de U5 att, uma vez que ele se encontra nas sequências de eudicotiledôneas e monocotiledôneas dos Clusters A e B. O U3 att não possui este tipo de diversificação, o que indica que um segundo tipo de U5 att apareceu ao longo da evolução destes elementos, sem grandes mudanças no U3 att. O fato dos 
dois sítios att serem reconhecidos pela integrase separadamente suporta essa descoberta (BERA et al., 2009; MASUDA et al., 1998).

O sítio U3 att é conservado dentro, mas não entre genomas, indicando que esses sítios podem ser úteis para a classificação de elementos em linhagens e também para estimar o número de LTRs presentes em cada genoma, como demonstrado por nós (Figura 3.7). Considerando o alto nível de conservação dos sítios att, nós esperamos que essas sequências podem ser utilizadas na identificação de linhagens autônomas responsáveis pela transposição de elementos não autônomos e até por LARDs (LArge Retrotransposon Derivatives).

\subsubsection{A LTR é a estrutura com maior plasticidade em elementos da linhagem Del}

Como outros estudos já mostraram, a diferença no tamanho de diversas cópias de LTR-RT da mesma linhagem frequentemente ocorre devido às diferenças nos tamanhos das LTRs, mas em alguns casos a causa é a variabilidade do tamanho de regiões intra-LTR não codificantes, como descrito para a linhagem Tat (DOMINGUES et al., 2012)). Para abordar essa questão, nós comparamos o tamanho das LTRs, o tamanho do elemento completo, e o tamanho da região interna do elemento, dois a dois.. Não encontramos correlação entre o tamanho da região interna com o tamanho das LTRs ou com o do elemento completo. Entretanto, encontramos uma correlação positiva entre o tamanho do elemento completo e o tamanho das LTRs. Concluímos então que a variação no tamanho da LTR é o grande responsável pela variação no tamanho dos elementos dessa linhagem (Figura 3.4).

\subsubsection{A presença de ilhas CpG nas LTRs de elementos da linhagem Del}

As LTRs de um retrotransposon não são apenas estruturas importantes para a integração de novas cópias, uma vez que elas carregam os promotores destes elementos, elas são também estruturas chave para a regulação da expressão dessas cópias. O mais bem estudado mecanismo que o genoma hospedeiro utiliza para silenciar os LTR-RTs é o silenciamento dos elementos mediado pela metilação de suas LTRs (CANTU et al., 2010).

Regiões de baixa complexidade ricas em GC à montante do TATA box foram descritas em algumas monocotiledôneas (BOUSIOS et al., 2010). Essas ilhas CpG geralmente se encontram desmetiladas em regiões promotoras de genes ativos, uma vez que a metilação dessas ilhas resulta em um gene epigeneticamente silenciado. Estudos mostraram que a presença de um motivo denominado $\mathrm{Sp} 1$ em ilhas $\mathrm{CpG}$ presentes na região 5' da LTR do 
Rous sarcoma vírus, ou dentro de um promotor de um gene, inibe a metilação mediada pelo hospedeiro (BRANDEIS et al., 1994; SENIGL et al., 2008).

Nós descrevemos três padrões distintos de elementos da linhagem $\mathrm{Del}$, acordo com a presença de ilhas CpG em suas LTRs (Figura 3.5). O primeiro padrão é aquele de elementos onde nenhuma ilha CpG é encontrada em suas LTRs. Esse padrão foi predominante nos elementos do cluster A, que inclui todas as eudicotiledôneas e é o mais próximo filogeneticamente dos grupos externos (com sequências de outras linhagens de Gypsy).

O segundo padrão consiste em elementos com uma ilha $\mathrm{CpG}$ em suas LTRs, geralmente encontrado no cluster B. Essa ilha CpG normalmente se localiza na região 5' das LTRs e está associada à uma baixa conservação de sequência (Figura 3.5 e Tabela 3.1). Essas ilhas CpG são mais plásticas do que o resto da LTR. Uma vez que essa região é um alvo conhecido para metilação mediada pelo genoma hospedeiro, nós sugerimos que essas ilhas CpG localizadas à 5' da LTR possibilite, de alguma maneira, que esses elementos escapem do controle do genoma hospedeiro, devido à sua grande variabilidade de conteúdo e tamanho.

O terceiro padrão consiste em duas ilhas CpG por LTR, a primeira é a mesma descrita acima enquanto a segunda se localiza mais a 3' da LTR (Figura 3.5). Diferente da ilha CpG da 5', a ilha CpG da 3' da LTR é associada à uma alta conservação de sequência. Este terceiro

padrão é comumente encontrado nos elementos do cluster C. Esse cluster possui outra característica que o distingue dos demais, o tipo B de U5 att, e é constituído apenas de sequência de S. bicolor, Z. mays e S. italica.

A distribuição desses três padrões sobre a árvore filogenética sugere que o aparecimento de ilhas $\mathrm{CpG}$ em elementos da linhagem Del é uma característica que apareceu em monocotiledôneas, depois da separação das eudicotiledôneas.

\subsubsection{A evolução da linhagem Del}

Classificamos os elementos da linhagem Del em nove grandes grupos, através de uma análise filogenética baseada na sequência nucleotídica dos domínios codificantes da RT e da RNAseH. Todas as 118 sequências oriundas de monocotiledôneas formaram um único grupo monofilético (Grupo I). Os outros oito grupos são compostos de 2314 sequências de elementos da linhagem Del provenientes de eudicotiledôneas (Figura 3.1). Apesar da tendência de grandes genomas carregarem um maior número de TEs em seus genomas, $G$. max tem um genoma grande, de $975 \mathrm{Mb}$, e encontramos apenas 33 cópias completas de elementos da linhagem Del no seu genoma. Por sua vez, $O$. sativa possui um genoma de 
apenas $372 \mathrm{Mb}$ e encontramos 240 cópias completas de elementos da linhagem Del em seu genoma. Nossos resultados sugerem que a linhagem Del expandiu e se diversificou com muito mais intensidade nas gramíneas, com exceção de B. distachyon, do que nos genomas de eudicotiledôneas. Estas diferenças podem estar relacionadas às diferenças em padrões de metilação ou à eficiência da maquinaria de silenciamento do genoma hospedeiro.

Cada característica estudada nas LTRs (ilhas CpG, sítios att, tamanho e plasticidade) foi caracterizada à luz da filogenia (Figura 3.1). O cluster $\mathrm{C}$ contém apenas sequências de $S$. italica, S. bicolor e Z. mays, e forma um grupo monofilético sustentado por um bootstrap de valor 99. LTRs do cluster $\mathrm{C}$ possuem algumas características particulares, como um tipo único de U5 att se comparado aos outros elementos da linhagem, assim como duas ilhas CpG em suas LTRs (exceto pelo subgrupo IX d, Tabela 3.1).

As três espécies que compõe o cluster $\mathrm{C}$ estão próximas filogeneticamente, o que sugere que estamos presenciando a insurgência de uma sublinhagem dentro da linhagem Del, exclusiva a algumas gramíneas. Por sua vez, não encontramos ilhas $\mathrm{CpG}$ nas LTRs de elementos do cluster A, com sequências de monocotiledôneas (Grupo I) e algumas eudicotiledôneas (Grupo II). Elementos desse cluster são menos bem sucedidos, em termos de número de cópias e diversidade.

\subsubsection{Distribuição de elementos da linhagem Del entre cromossomos de milho e sorgo}

Como já foi abordado na literatura, elementos transponíveis podem possuir sítios preferenciais de inserção e algumas vezes se encontram agrupados nos genomas (BENNETZEN, 2000). Surpreendentemente, as cópias de elementos da linhagem Del se mostraram desigualmente distribuídas entre os diferentes cromossomos de milho e sorgo. Dentre os casos encontrados, dois são particularmente curiosos.

O primeiro é o cromossomo 1 de sorgo, que possui um número relativo menor de cópias completas e de U3 att do que os demais cromossomos desse genoma. Uma vez que aceitamos que os U3 att representam LTRs de elementos da linhagem estudada, podemos supor que esse número inclua: cópias completas, cópias truncadas e solo LTRs. Nossos resultados indicam que, comparado aos outros cromossomos de sorgo, o cromossomo 1 foi alvo de um número menor de inserções de elementos $\mathrm{Del}$ ou que a eliminação desses elementos aconteceu mais rapidamente.

Um mecanismo conhecido que gera a eliminação de LTR-RTs de genomas é a recombinação das duas LTRs do mesmo elemento, deixando no genoma apenas uma solo 
LTR (JORDAN; MCDONALD, 1999). Durante a recombinação, uma LTR e a região intraLTRs são removidas do genoma. Uma eliminação mais rápida do elemento de um cromossomo poderia ocorrer devido a diferentes taxas de recombinação entre os cromossomos do genoma, como já foi descrito para ratos (NACHMAN; CHURCHILL, 1996). Isto poderia explicar o baixo número de elementos completos e de U3 att da linhagem Del, encontrados no cromossomo 1 de sorgo.

O segundo é o caso dos cromossomos 6 e 7 de milho, onde encontramos um número de cópias completas de elementos da linhagem Del menor do que nos outros cromossomos desse genoma. Entretanto, todos os cromossomos deste genoma apresentaram um número similar de sítios U3 att. Esses resultados sugerem que existe um número maior de cópias truncadas nos cromossomos 6 e 7 do que nos demais. Ao mesmo tempo em que o número de U3 att indica que o número de solo LTRs presente nesses cromossomos não é significativamente diferente dos demais cromossomos. Uma hipótese para explicar esses resultados seria a de que esses cromossomos possuem um grande número de elementos inseridos dentro de outros elementos. Fica aparente a necessidade de investigar melhor estes resultados em estudos posteriores.

\subsection{Conclusão}

A abordagem genômica comparativa entre 10 genomas de angiospermas e 2432 cópias de LTR-RT da linhagem Del permitiu, pela primeira vez, identificar características compartilhadas entre cópias de toda a linhagem e outras restritas a algum ramo da árvore filogenética proposta. A distribuição desigual de elementos da linhagem Del entre os diferentes cromossomos de sorgo e milho é uma característica comum a toda a linhagem (não é específica de um ou outro grupo) e sugere uma evolução desigual de TEs em diferentes cromossomos. Outra característica comum a toda linhagem Del é a variabilidade de tamanho de suas LTRs.

Os sítios att foram encontrados em todos os grupos de Del havendo dois tipos de U5 att identificados (A e B) associados aos dois maiores ramos da árvore filogenética. Esses resultados indicam que elementos da linhagem Del são transpostos apenas por integrases da mesma linhagem. O surgimento de um novo tipo de U5 att pode indicar o surgimento de uma nova sublinhagem, composta pelos grupos VII-IX. Por outro lado, a alta conservação do U3 att dentre todos os genomas estudados é um indício claro da importância dessa região para a especificidade da integração. 
Como mostramos no capítulo 1, elementos Del de cana-de-açúcar de famílias diferentes apresentaram diferentes comportamentos (mapeamento de sRNAs e expressão). A região 5' das LTRs é responsável pela regulação trancricional desses elementos e a grande plasticidade da ilha CpG na região da 5' da LTR da linhagem Del podem impactar no padrão de metilação e silenciamento transcricional dessas cópias.

Em monocotiledôneas encontramos um grande número e grande diversidade de elementos da linhagem Del, enquanto em eudicotiledôneas encontramos um panorama contrastante, com poucos elementos e uma diversidade menor. Nossa hipótese é que a presença das ilhas $\mathrm{CpG}$ (muito plásticas) nas LTRs poderia ajudar os elementos a escaparem do silenciamento ao se tornarem um "alvo móvel", pois encontramos uma ou mais ilhas $\mathrm{CpG}$ nas LTRs de elementos $\mathrm{Del}$ em eudicotiledôneas, enquanto em monocotiledôneas elas são exceção.

Mudanças nas LTRs (ex: presença de ilhas CpG, U5 att e tamanho) são concomitantes a pequenas variações de sequência na região codificante dos elementos, como evidenciado ao sobrepor essas análises à árvore filogenética. As características únicas de elementos do cluster C sugerem que esse é um produto intermediário da evolução dessa linhagem, que pode levar a formação de uma nova linhagem, emergindo nas monocotiledôneas. 


\section{CONCLUSÃO GERAL}

Ao longo destes quatro anos de estudo conseguimos avançar no entendimento de diversidade, estrutura e evolução dos LTR-RTs. Os resultados obtidos através de muitas colaborações resultaram em seis artigos publicados e dois em fase de submissão, que estão listados no APÊNDICE H. Ainda assim, como toda tese, este trabalho trouxe novas questões à tona que esperamos um dia poder responder.

O capítulo 1, que abordou a classificação de LTR-RTs de cana-de-açúcar, foi o único grande trabalho até o momento com este foco em uma espécie tão importante para a agricultura brasileira. Os elementos não só foram catalogados em linhagens, como exploramos as diferenças comportamentais das diferentes famílias dentro de cada linhagem encontrada. Mostramos que famílias de uma mesma linhagem podem possuir perfis transcricionais e mapeamento de sRNA distintos. No futuro, esperamos que este tipo de estudo se torne mais comum.

Foi feita uma análise de diversidade focando em três famílias de diferentes linhagens (scAle1, scDel1 e scMaximus1). Esta análise mostrou que os genomas parentais tiveram contribuições diferentes para cada família estudada. Interessantemente, a linhagem Del é heterocromática enquanto Ale é eucromática. Sobrepondo esta informação com nossos resultados, podemos inferir que a contribuição dos parentais para a composição da heterocromatina dos cultivares modernos é distinta, com a prevalência de elementos derivados de S.officinarum. Isso pode ser levado em consideração na busca por elementos a serem utilizados como marcadores moleculares para melhoramento genético.

A hibridização in situ mostrou que elementos da família scAle1 estão transcricionalmente ativos durante a formação de raízes laterais de cana-de-açúcar. Não podemos concluir a causa dessa atividade, mas sabemos que este tecido está em crescimento e nesta região muitas células vegetais estão se diferenciando. Esse tipo de experimento pode ser realizado com mais frequência no futuro, já que é uma maneira rápida de comparar a atividade de diferentes famílias de elementos em diferentes tecidos vegetais.

A descoberta de sítios att nos LTR-RTs possibilitou a reflexão acerca da co-evolução desses sítios com a integrase dos elementos. Em vírus, este assunto já foi um pouco explorado e levou a conclusão de que a conservação dos sítios att ocorre porque esses só podem mudar se a integrase mudar ao mesmo tempo. Estudos mais detalhados nesta possível coevolução em LTR-RTs, como a avaliação de frequência de inserção aliada à análise de mutações pontuais em ambas as estruturas, poderão esclarecer este tema. 
A análise que mostrou o diferente número de LTR-RTs e sítios U3 att presentes nos cromossomos de sorgo e milho foi inovadora. Os resultados encontrados sugerem que novas cópias "evitam" a inserção em alguns cromossomos específicos, ou ainda, que alguns cromossomos possuem uma taxa de eliminação mais veloz desses elementos do que outros. De qualquer maneira, a mesma análise aplicada a outras linhagens ou outros genomas pode fornecer pistas importantes sobre a evolução dos genomas. 


\section{REFERÊNCIAS*}

ALIX, K. et al. The genomic organization of retrotransposons in Brassica oleracea. Plant Molecular Biology, v. 59, n. 6, p. 839-851, 2005.

ARAUJO, P. G. et al. Retrolyc1 subfamilies defined by different U3 LTR regulatory regions in the Lycopersicon genus. Molecular Genetics and Genomics, v. 266, n. 1, p. 35-41, 2001.

ARAUJO, P. G. et al. Transcriptionally active transposable elements in recent hybrid sugarcane. The Plant Journal: for Cell and Molecular Biology, v. 44, n. 5, p. 707-717, 2005a.

ARAUJO, P. G. et al. Transcriptionally active transposable elements in recent hybrid sugarcane. The Plant Journal, v. 44, n. 5, p. 707-717, 2005 b.

BANDELT, H.-J.; FORSTER, P.; RÖHL, A. Median-joining networks for inferring intraspecific phylogenies. Molecular biology and evolution, v. 16, p. 37-48, 1999.

BAUCOM, R. S. et al. Exceptional diversity, non-random distribution, and rapid evolution of retroelements in the B73 maize genome. PLoS genetics, v. 5, n. 11, p. e1000732, 2009.

BAULCOMBE, D. RNA silencing in plants. Nature, v. 431, n. 7006, p. 356-363, 2004.

BENACHENHOU, F. et al. Conserved structure and inferred evolutionary history of long terminal repeats (LTRs). Mobile DNA, v. 4, n. 1, p. 5, 2013.

BENNETZEN, J. L. Transposable element contributions to plant gene and genome evolution. Plant Molecular Biology, v. 42, n. 1, p. 251-269, 2000.

BENNETZEN, J. L. Transposable elements, gene creation and genome rearrangement in flowering plants. Current Opinion in Genetics \& Development, v. 15, n. 6, p. 621-627, 2005 .

BENNETZEN, J. L. et al. Consistent over-estimation of gene number in complex plant genomes. Current Opinion in Plant Biology, v. 7, n. 6, p. 732-736, 2004.

BERA, S. et al. Molecular Interactions between HIV-1 integrase and the two viral DNA ends within the synaptic complex that mediates concerted integration. Journal of Molecular Biology, v. 389, n. 1, p. 183-198, 2009.

BOUSIOS, A. et al. Highly conserved motifs in non-coding regions of Sirevirus retrotransposons: the key for their pattern of distribution within and across plants? BMC Genomics, v. 11, p. 89, 2010.

*De acordo com:

ASSOCIAÇÃO BRASILEIRA DE NORMAS TÉCNICAS. NBR 6023: informação e documentação: referências: elaboração. Rio de Janeiro, 2002. 
BRANDEIS, M. et al. Sp1 elements protect a CpG island from de novo methylation. Nature, v. 371, n. 6496, p. 435-438, 1994.

BROWN, H. E.; CHEN, H.; ENGELMAN, A. Structure-based mutagenesis of the human immunodeficiency virus type 1 DNA attachment site: effects on integration and cDNA synthesis. Journal of Virology, v. 73, n. 11, p. 9011-9020, 1999.

CANTU, D. et al. Small RNAs, DNA methylation and transposable elements in wheat. BMC Genomics, v. 11, p. 408, 2010.

CASACUBERTA, J. M.; SANTIAGO, N. Plant LTR-retrotransposons and MITEs: control of transposition and impact on the evolution of plant genes and genomes. Gene, v. 311, p. 1-11, 2003.

CASTRO, P. R. C.; KLUGE, R. A. Ecofisiologia de culturas extrativas. cana-de-açúcar, seringueira, coqueiro, dendezeiro e oliveira. Cosmópolis: Stoller do Brasil, 2001.

CHIU, R.; GRANDGENETT, D. P. Avian retrovirus DNA internal attachment site requirements for full-site integration in vitro. Journal of Virology, v. 74, n. 18, p. 82928298, 2000.

COSTA, A P. et al. Retrolyc1-1, a member of the Tntl retrotransposon super-family in the Lycopersicon peruvianum genome. Genetica, v. 107, n. 1-3, p. 65-72, 1999.

DANIELS, J.; ROACH, B. T. Taxonomy and evolution in sugarcane. Sugarcane Improvement Through Breeding, p.7-84, 1987.

DEMARCO, R. et al. Retrotransposons with high transcriptional activities from the human parasite Schistosoma mansoni Saci-1, -2 , and -3 and Perere, four novel retrotransposons with high transcriptional activities from the human parasite Schistosoma mansoni. Journal of Virology, v. 78, n. 6, p. 2967-2978, 2004.

DEMARCO, R. et al. Identification of 18 new transcribed retrotransposons in Schistosoma mansoni. Biochemical and Biophysical Research Communications, v. 333, n. 1, p. 230-40, 2005 .

DOMINGUES, D. S. et al. Analysis of plant LTR-retrotransposons at the fine-scale family level reveals individual molecular patterns. BMC Genomics, v. 13, n. 1, p. 137, 2012.

DU, J. et al. Evolutionary conservation, diversity and specificity of LTR-retrotransposons in flowering plants: insights from genome-wide analysis and multi-specific comparison. Plant Journal, v. 63, n. 4, p. 584-598, 2010.

DUVICK, J. et al. PlantGDB: a resource for comparative plant genomics. Nucleic Acids Research, v. 36, n. Database issue, p. D959-965, 2008.

ECHENIQUE, V. et al. Frequencies of Ty1- copia and Ty3-gypsy retroelements within the Triticeae EST databases. Theoretical and applied genetics, v. 104, n. 5, p. 840-844, 2002. 
EDGAR, R. C. MUSCLE: multiple sequence alignment with high accuracy and high throughput. Nucleic Acids Research, v. 32, n. 5, p. 1792-1797, 2004.

FESCHOTTE, C.; JIANG, N.; WESSLER, S. R. Plant transposable elements: where genetics meets genomics. Nature Reviews Genetics, v. 3, n. 5, p. 329-341, 2002.

FINK, J.; HAMILTON, N. DomainDraw: a macromolecular schematic drawing program. In Silico Biology, v. 7, p. 14, 2007.

FLAVELL, A. J.; PEARCE, S. R.; KUMAR, A. Plant transposable elements and the genome. Current Opinion in Genetics \& Development, v. 4, n. 6, p. 838-844, 1994.

GALINDO, L. M. et al. Isolation and characterization of RNase LTR sequences of Ty1- copia retrotransposons in common bean ( Phaseolus vulgaris L .). Genome, v. 95, p. 84-95, 2004.

GAO, X. et al. Chromodomains direct integration of retrotransposons to heterochromatin. Genome Research, v. 18, p. 359-369, 2008.

GARSMEUR, O. et al. High homologous gene conservation despite extreme autopolyploid redundancy in sugarcane. New Phytologist, n. 2010, p. 629-642, 2010.

GRANDBASTIEN, M. A.; SPIELMANN, A.; CABOCHE, M. Tnt1, a mobile retroviral-like transposable element of tobacco isolated by plant cell genetics. Nature, v. 377, p. 376-380, 1989.

GRIFFITHS, A. J. F. et al. Genética moderna. 2001.

GRIVET, L.; ARRUDA, P. Sugarcane genomics: depicting the complex genome of an important tropical crop. Current Opinion in Plant Biology, v. 5, n. 2, p. 122-127, 2002.

HALL, T. BioEdit: a user-friendly biological sequence alignment editor and analysis program for Windows 95/98/NT. Nucleic Acids Symposium Series, v. 41, p. 95-98, 1999.

HAMILTON, A. et al. Two classes of short interfering RNA in RNA silencing. The EMBO journal, v. 21, n. 17, p. 4671-4679, 2002.

HAVECKER, E.; GAO, X.; VOYTAS, D. The diversity of LTR retrotransposons. Genome Biology, v. 5, n. 6, p. 225, 2004.

HIROCHIKA, H. Activation of tobacco. EMBO Journal, v. 12, n. 6, p. 2521-2528, 1993. HOTTA, C. T. et al. The Biotechnology Roadmap for Sugarcane Improvement. Tropical Plant Biology, v. 3, n. 2, p. 75-87, 2010.

HRIBOVÁ, E. et al. Repetitive part of the banana (Musa acuminata) genome investigated by low-depth 454 sequencing. BMC Plant Biology, v. 10, p. 204, 2010.

JANNOO, N. et al. Orthologous comparison in a gene-rich region among grasses reveals stability in the sugarcane polyploid genome. The Plant Journal: For Cell and Molecular Biology, v. 50, n. 4, p. 574-585, 2007. 
DE JESUS, E. M. et al. Diversification of hAT transposase paralogues in the sugarcane genome. Molecular Genetics and Genomics: MGG, v. 287, n. 3, p. 205-219, 2012.

JIANG, N. et al. Dasheng: a recently amplified nonautonomous long terminal repeat element that is a major component of pericentromeric regions in rice. Genetics, v. 161, n. 3, p. 1293$1305,2002$.

JIANG, N. et al. Pack-MULE transposable elements mediate gene evolution in plants. Nature, v. 431, p. 569-573, 2004.

JORDAN, I. K.; MCDONALD, J. F. The role of interelement selection in Saccharomyces cerevisiae Ty element evolution. Journal of Molecular Evolution, v. 49, n. 3, p. 352-357, 1999.

KALENDAR, R. et al. Large retrotransposon derivatives: abundant, conserved but nonautonomous retroelements of barley and related genomes. Genetics, v. 166, n. 3, p. 14371450, 2004.

KALENDAR, R. et al. Genome evolution of wild barley (Hordeum spontaneum) by BARE-1 retrotransposon dynamics in response to sharp microclimatic divergence. Proceedings of the National Academy of Sciences, v. 97, p. 6603-6607, 2000.

KANG, S. Y. et al. Functional nucleotides of U5 LTR determining substrate specificity of prototype foamy virus integrase the evolution of del retrotransposon lineage in plants. Journal of Microbiology Biotechnology, v. 18, n. 6, p. 1044-1049, 2008.

KUMAR, A. The adventures of the Ty1-copia group of retrotransposons in plants. Trends In Genetics: TIG, v. 12, n. 2, p. 41-43, 1996.

KUMAR, A.; BENNETZEN, J. L. Plant Retrotransposons. Annual Review of Genetics, v. 33, p. 479-532, 1999.

LARSEN, F. et al. CpG islands as gene markers in the human genome. Genomics, v. 13, n. 4, p. 1095-107, 1992.

LASSMANN, T.; SONNHAMMER, E. L. L. Kalign--an accurate and fast multiple sequence alignment algorithm. BMC Bioinformatics, v. 6, p. 298, 2005.

LATEN, H. M.; MAJUMDAR, A; GAUCHER, E. A. SIRE-1, a copia/Ty1-like retroelement from soybean, encodes a retroviral envelope-like protein. Proceedings of the National Academy of Sciences, v. 95, n. 12, p. 6897-6902, 1998.

LI, H.; RUAN, J.; DURBIN, R. Mapping short DNA sequencing reads and calling variants using mapping quality scores. Genome Research, v. 18, n. 11, p. 1851-1858, 2008.

LLORENS, C. et al. The Gypsy Database (GyDB) of mobile genetic elements: release 2.0. Nucleic Acids Research, v. 39, p. D70-4, 2011. 
MANETTI, M. E. et al. The Tnt1 family member Retrosol copy number and structure disclose retrotransposon diversification in different Solanum species. Molecular Genetics and Genomics: MGG, v. 281, n. 3, p. 261-271, 2009.

MANNINEN, I.; SCHULMAN, A H. BARE-1, a copia-like retroelement in barley (Hordeum vulgare L.). Plant Molecular Biology, v. 22, n. 5, p. 829-846, 1993.

MARTINEZ-IZQUIERDO, J. A.; GARCIA-MARTINEZ, J.; VICIENT, C. . What makes Grande1 retrotransposon different? Genetica, v. 100, n. 1-3, p. 15-28, 1997.

MASUDA, T.; KURODA, M. J.; HARADA, S. Specific and independent recognition of U3 and U5 att sites by human immunodeficiency virus type 1 integrase in vivo. Journal of Virology, v. 72, n. 10, p. 8396-8402, 1998.

MATSUOKA, Y.; TSUNEWAKI, K. Evolutionary dynamics of Ty1-copia group retrotransposons in grass shown by reverse transcriptase domain analysis. Molecular Biology and Evolution, v. 16, n. 2, p. 208-217, 1999.

MCCARTHY, E. M. et al. Long terminal repeat retrotransposons of Oryza sativa. Genome Biology, v. 3, n. 10, p. RESEARCH0053, 2002.

MCCARTHY, E. M.; MCDONALD, J. F. LTR_STRUC: a novel search and identification program for LTR retrotransposons. Bioinformatics, v. 19, n. 3, p. 362-367, 2003.

MHIRI, C. et al. The promoter of the tobacco Tnt1 retrotransposon is induced by wounding and by abiotic stress. Plant Molecular Biology, v. 33, n. 2, p. 257-266, 1997.

NACHMAN, M. W.; CHURCHILL, G. A. Heterogeneity in rates of recombination across the mouse genome. Genetics, v. 548, n. 142, p. 537-548, 1996.

NOBUTA, K. et al. Distinct size distribution of endogeneous siRNAs in maize: Evidence from deep sequencing in the mop1-1 mutant. Proceedings of the National Academy of Sciences of the United States of America, v. 105, n. 39, p. 14958-63, 2008.

NOMA, K. et al. RIRE1, a retrotransposon from wild rice Oryza australiensis. Genes \& Genetic Systems, v. 72, n. 3, p. 131-140, 1997.

NOVIKOV, A.; SMYSHLYAEV, G.; NOVIKOVA, O. Evolutionary history of LTR retrotransposon chromodomains in plants. International Journal of Plant Genomics, v. 2012, p. 874743, 2012.

ORTIZ-MOREA, F. A. et al. Global analysis of the sugarcane microtranscriptome reveals a unique composition of small RNAs associated with axillary bud outgrowth. Journal of Experimental Botany, v. 64, n. 8, p. 2307-2320, 2013.

PAPINI-TERZI, S. et al. Transcription Profiling of Signal Transduction-Related Genes in. DNA Research, v. 38, p. 27-38, 2005.

PARDUE, M. L.; DEBARYSHE, P. G. Drosophila telomeres: two transposable elements with important roles in chromosomes. Genetica, v. 107, n. 1-3, p. 189-196, 1999. 
PARK, M. et al. Comparative analysis of pepper and tomato reveals euchromatin expansion of pepper genome caused by differential accumulation of Ty3/Gypsy-like elements. BMC Genomics, v. 12, n. 1, p. 85, 2011.

PASYUKOVA, E. G. et al. Accumulation of transposable elements in the genome of Drosophila melanogaster is associated with a decrease in fitness. The Journal of Heredity, $v$. 95, n. 4, p. 284-290, 2004.

PATERSON, A. H. et al. The Sorghum bicolor genome and the diversification of grasses. Nature, v. 457, n. 7229, p. 551-556, 2009.

PELSY, F.; MERDINOGLU, D. Complete sequence of Tvv1, a family of Ty 1 copia-like retrotransposons of Vitis vinifera L., reconstituted by chromosome walking. Theoretical and Applied Genetics, v. 105, n. 4, p. 614-621, 2002.

PERLMAN, P. S.; BOEKE, J. D. Molecular biology. Ring around the retroelement. Science, v. 303, n. 5655, p. 182-184, 2004.

PIPERIDIS, G.; PIPERIDIS, N.; D'HONT, A. Molecular cytogenetic investigation of chromosome composition and transmission in sugarcane. Molecular Genetics and Genomics: MGG, v. 284, n. 1, p. 65-73, 2010.

PRESTING, G. G. et al. A Ty3/gypsy retrotransposon-like sequence localizes to the centromeric regions of cereal chromosomes. The Plant Journal: For Cell and Molecular Biology, v. 16, n. 6, p. 721-8, 1998.

PUNTA, M. et al. The Pfam protein families database. Nucleic Acids Research, v. 40, p. D290-D301, 2012.

ROSSI, M.; VAN SLUYS, M-A. Survey of transposable elements in sugarcane expressed sequence tags ( ESTs ). Genetics and Molecular Biology, v. 24, p. 147-154, 2001.

ROZAS, J.; ROZAS, R. DnaSP, DNA sequence polymorphism: an interactive program for estimating Population Genetics parameters from DNA sequence data. Bioinformatics, v. 11, p. 621-625, 1995.

SACCARO, N. L. et al. MudrA-like sequences from rice and sugarcane cluster as two bona fide transposon clades and two domesticated transposases. Gene, v. 392, n. 1-2, p. 117-125, 2007.

SAMBROOK, J.; FRITSCH, E.; MANIATIS, T. Molecular Cloning: a Laboratory Manual. 2nd ed. New York: Cold Spring Harbor Laboratory Press, 1989.

SANMIGUEL, P. et al. Nested retrotransposons in the intergenic regions of the maize genome. Science, v. 274, n. 5288, p. 765-768, 1996.

SAYERS, E. W. et al. Database resources of the National Center for Biotechnology Information. Nucleic Acids Research, v. 39, p. 38-51, 2011. 
SCHULMAN, A H.; KALENDAR, R. A movable feast: diverse retrotransposons and their contribution to barley genome dynamics. Cytogenetic and Genome Research, v. 110, n. 1-4, p. 598-605, 2005.

SENIGL, F.; PLACHÝ, J.; HEJNAR, J. The core element of a CpG island protects avian sarcoma and leukosis virus-derived vectors from transcriptional silencing. Journal of Virology, v. 82, n. 16, p. 7818-7827, 2008.

SLOTKIN, R. K.; MARTIENSSEN, R. Transposable elements and the epigenetic regulation of the genome. Nature Review Genetics, v. 8, n. 4, p. 272-285, 2007.

SOUZA, G. M. et al. The sugarcane signal transduction (SUCAST) catalogue : prospecting signal transduction in sugarcane. Genetics and Molecular Biology, v. 24, p. 25-34, 2001.

STOTHARD, P. The Sequence Manipulation Suite: JavaScript programs for analyzing and formatting protein and DNA sequences. Biotechniques, v. 28, p. 1102-1104, 2000.

SUONIEMI, A; SCHMIDT, D.; SCHULMAN, A H. BARE-1 insertion site preferences and evolutionary conservation of RNA and cDNA processing sites. Genetica, v. 100, n. 1-3, p. 219-230, 1997.

SUONIEMI, A; TANSKANEN, J.; SCHULMAN, A H. Gypsy-like retrotransposons are widespread in the plant kingdom. The Plant Journal : For Cell and Molecular Biology, v. 13, n. 5, p. 699-705, 1998.

TAMURA, K. et al. MEGA5: molecular evolutionary genetics analysis using maximum likelihood, evolutionary distance, and maximum parsimony methods. Molecular Biology and Evolution, v. 28, n. 10, p. 2731-2739, 2011a.

TOMKINS, J. P. et al. A bacterial artificial chromosome library for sugarcane. Theoretical and Applied Genetics, v. 99, n. 3-4, p. 419-424, 1999.

VERNHETTES, S.; GRANDBASTIEN, M. A.; CASACUBERTA, J. M. The evolutionary analysis of the Tnt 1 retrotransposon in Nicotiana species reveals the high variability of its regulatory sequences. Molecular Biology and Evolution, v. 15, n. 7, p. 827-836, 1998.

VETTORE, A. L. et al. The libraries that made SUCEST. Genetics and Molecular Biology, v. 24, p. 1-7, 2001.

VICIENT, C. M. Transcriptional activity of transposable elements in maize. BMC Genomics, v. 11, n. 1, p. 601, 2010. BioMed Central Ltd.

VINCENTZ, M. et al. Evaluation of Monocot and Eudicot Divergence Using the Sugarcane Transcriptome. Plant Physiology, p. 951-959, 2004.

VITTE, C.; PANAUD, O. LTR retrotransposons and flowering plant genome size: emergence of the increase/decrease model. Cytogenetic and Genome Research, v. 110, n. 1-4, p. 91$107,2005$. 
VOYTAS, D. F. et al. Copia-Like Retrotransposons Are Ubiquitous Among Plants. Proceedings of the National Academy of Sciences of the United States of America, v. 89, n. 15, p. 7124-7128, 1992.

WANG, H.; LIU, J.-S. LTR retrotransposon landscape in Medicago truncatula: more rapid removal than in rice. BMC Genomics, v. 9, p. 382, 2008.

WANG, J. et al. Microcollinearity between autopolyploid sugarcane and diploid sorghum genomes. BMC Genomics, v. 11, p. 261, 2010.

WATERHOUSE, A. M. et al. Jalview Version 2--a multiple sequence alignment editor and analysis workbench. Bioinformatics, v. 25, n. 9, p. 1189-1191, 2009.

WICKER, T.; KELLER, B. Genome-wide comparative analysis of copia retrotransposons in Triticeae, rice, and Arabidopsis reveals conserved ancient evolutionary lineages and distinct dynamics of individual copia families. Genome Research, v. 17, n. 7, p. 1072-1081, 2007.

WICKER, T. et al. A unified classification system for eukaryotic transposable elements. Nature Review Genetics, v. 8, n. 12, p. 973-782, 2007.

WITTE, C. P. et al. Terminal-repeat retrotransposons in miniature (TRIM) are involved in restructuring plant genomes. Proceedings of the National Academy of Sciences of the United States of America, v. 98, n. 24, p. 13778-13783, 2001.

WRIGHT, D. A.; VOYTAS, D. F. Potential retroviruses in plants: Tat1 is related to a group of Arabidopsis thaliana Ty3/gypsy retrotransposons that encode envelope-like proteins. Genetics, v. 149, n. 2, p. 703-715, 1998.

XIONG, Y.; EICKBUSH, T. H. Origin and evolution of retroelements based their reverse transcriptase sequences. EMBO Journal, v. 9, n. 10, p. 3353-3362, 1990.

ZHANG, P. et al. BAC-FISH in wheat identifies chromosome landmarks consisting of different types of transposable elements. Chromosoma, v. 112, n. 6, p. 288-299, 2004.

ZHANG, X. et al. Genome-wide high-resolution mapping and functional analysis of DNA methylation in arabidopsis. Cell, v. 126, n. 6, p. 1189-1201, 2006.

ZUKER, M. Mfold web server for nucleic acid folding and hybridization prediction. Nucleic Acids Research, v. 31, n. 13, p. 3406-3415, 2003. 


\section{APENDICES}

APÊNDICE A - Informações sobre os LTR-RT encontrados em cana-de-açúcar.

\begin{tabular}{|c|c|c|c|c|c|c|c|c|}
\hline Nome do LTR-RT & Nome Pré-existente & Superfamília_Linhagem & Número de acesso & $5^{\prime}$ & $3^{\prime}$ & $5^{\prime}$ & $3^{\prime}$ & $\begin{array}{c}\text { Tamanho do } \\
\text { LTR-RT }\end{array}$ \\
\hline RLC_scAle_1.1 & Hopscotch-like & Copia_Ale & [GenBank:JN800006] & 116 & 116 & gttac & gttac & 4972 \\
\hline RLC_scAle_1.2 & Hopscotch-like & Copia_Ale & [GenBank:JN800007] & 117 & 117 & caagc & caagc & 5968 \\
\hline RLC_scAle_1.3 & Hopscotch-like & Copia_Ale & [GenBank:JN800008] & 114 & 114 & gatcc & gatcc & 5666 \\
\hline RLC_scAle_1.4 & Hopscotch-like & Copia_Ale & [GenBank:JN800005] & 116 & 116 & agatg & agatg & 4775 \\
\hline RLC_scAle_2.1 & & Copia_Ale & [GenBank:JN800009] & 238 & 238 & ctaac & ctaac & 4851 \\
\hline RLC_scAle_3.1 & Hopscotch-like & Copia_Ale & [GenBank:JN800010] & 189 & 189 & gtgtt & gtgtt & 4789 \\
\hline RLC_scAle_4.1 & & Copia_Ale & [GenBank:JN800011] & 223 & 223 & accc & gaccc & 4875 \\
\hline RLC_scAle_5.1 & & Copia_Ale & [GenBank:JN800012] & 198 & 198 & aaacc & aaacc & 5305 \\
\hline RLC_scAngela_1.1 & & Copia_Angela & [GenBank:JN800013] & 445 & 445 & ggggc & ggggc & 6661 \\
\hline RLC_scAngela_2.1 & Stonor-like & Copia_Angela & [GenBank:JN800014] & 461 & 461 & gtgcg & gtgcg & 8573 \\
\hline RLC_scAngela_3.1 & & Copia_Angela & [GenBank:JN800015] & 434 & 434 & tacct & tacct & 6564 \\
\hline RLC_sclvana_1.1 & Tnt1-like & Copia_Ivana & [GenBank:JN800016] & 239 & 239 & ctatc & ctatc & 5276 \\
\hline RLC_sclvana_1.2 & Tnt1-like & Copia_Ivana & [GenBank:JN800017] & 238 & 238 & gtttg & gtttg & 5279 \\
\hline$R L C$ sclvana_1.3 & Tnt1-like & Copia_Ivana & [GenBank:JN800018] & 238 & 238 & cggtc & cggtc & 5268 \\
\hline RLC_sclvana_2.1 & & Copia_Ivana & [GenBank:JN800019] & 408 & 408 & gactc & gactc & 5205 \\
\hline RLC_sclvana_3.1 & & Copia_Ivana & [GenBank:JN800020] & 454 & 454 & ttcct & ttcct & 5300 \\
\hline RLC_sclvana_4.1 & & Copia_Ivana & [GenBank:JN800021] & 427 & 427 & gatca & gatca & 5325 \\
\hline RLC_sclvana_5.1 & & Copia_Ivana & [GenBank:JN800022] & 282 & 282 & $\operatorname{gccgc}$ & gccac & 5036 \\
\hline RLC_sclvana_6.1 & & Copia_Ivana & [GenBank:JN800023] & 249 & 249 & $\operatorname{tgcac}$ & $\operatorname{tgcac}$ & 5952 \\
\hline RLC_scMaximus_1.1 & Opie-like & Copia_Maximus & [GenBank:JN800024] & 1718 & 1698 & cacac & cacat & 13658 \\
\hline RLC_scMaximus_1.2 & Opie-like & Copia_Maximus & [GenBank:JN800025] & 1596 & 1597 & cgcag & cgcag & 13327 \\
\hline RLC_scMaximus_1.3 & Opie-like & Copia_Maximus & [GenBank:JN800026] & 1624 & 1623 & gagtg & gagt & 13454 \\
\hline RLC_scMaximus_1.4 & Opie-like & Copia_Maximus & [GenBank:JN800027] & 1581 & 1581 & agctc & agctc & 13391 \\
\hline RLC_scMaximus_1.5 & Opie-like & Copia_Maximus & [GenBank:JN800028] & 1670 & 1719 & caccg & caccg & 13518 \\
\hline RLC_scMaximus_1.6 & Opie-like & Copia_Maximus & [GenBank:JN800029] & 1607 & 1601 & gagtc & gagtc & 11957 \\
\hline
\end{tabular}




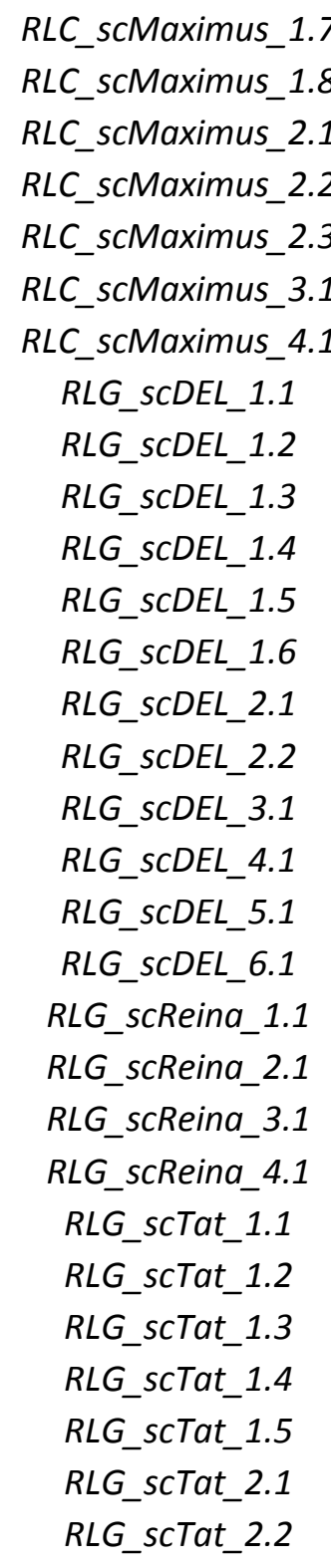

Opie-like
Opie-like
RLC_Rhum/Opie-like
RLC_Rhum/Opie-like
RLC_Rhum/Opie-like
RLC_Rhum
RLC_Rhum

RLG_TiPunch/Maggy-like/Tekay-like RLG_TiPunch/Maggy-like/Tekay-like RLG_TiPunch/Maggy-like/Tekay-like RLG_TiPunch/Maggy-like/Tekay-like RLG_TiPunch/Maggy-like/Tekay-like RLG_TiPunch/Maggy-like/Tekay-like

RLG_Cachaca/Maggy-like

$$
\begin{aligned}
& \text { RLG_Colada } \\
& \text { RLG_Colada } \\
& \text { RLG_Colada } \\
& \text { RLG_Colada } \\
& \text { RLG_Colada }
\end{aligned}
$$

Copia_Maximus
Copia_Maximus
Copia_Maximus
Copia_Maximus
Copia_Maximus
Copia_Maximus
Copia_Maximus
Gypsy_Del
Gypsy_Del
Gypsy_Del
Gypsy_Del
Gypsy_Del
Gypsy_Del
Gypsy_Del
Gypsy_Del
Gypsy_Del
Gypsy_Del
Gypsy_Del
Gypsy_Del
Gypsy_Reina
Gypsy_Reina
Gypsy_Reina
Gypsy_Reina
Gypsy_Tat
Gypsy_Tat
Gypsy_Tat
Gypsy_Tat
Gypsy_Tat
Gypsy_Tat
Gypsy_Tat

$\begin{array}{lccccc}\text { [GenBank:JN800030] } & 1646 & 1621 & \text { catca } & \text { catca } & 13476 \\ \text { [GenBank:JN800031] } & 1609 & 1607 & \text { atatc } & \text { atatc } & 13517 \\ \text { [GenBank:JN800032] } & 2256 & 2229 & \text { gaggg } & \text { gaggg } & 11027 \\ \text { [GenBank:JN800033] } & 2289 & 2287 & \text { acggt } & \text { acggt } & 11104 \\ \text { [GenBank:JN800034] } & 2316 & 2315 & \text { acggt } & & 10211 \\ \text { [GenBank:JN800035] } & 1980 & 1984 & \text { ctggc } & \text { ctggc } & 10589 \\ \text { [GenBank:JN800036] } & 2004 & 2008 & \text { atatt } & \text { atat } & 10448 \\ \text { [GenBank:JN800037] } & 5139 & 5127 & \text { cttca } & \text { cttca } & 16712 \\ \text { [GenBank:JN800038] } & 5012 & 5010 & \text { gtagt } & \text { gtagt } & 16454 \\ \text { [GenBank:JN800039] } & 4837 & 4837 & \text { caacg } & \text { caacg } & 16124 \\ \text { [GenBank:JN800040] } & 4832 & 4829 & \text { atctt } & \text { atctt } & 16113 \\ \text { [GenBank:JN800041] } & 4837 & 4835 & \text { cccta } & \text { cccta } & 16125 \\ \text { [GenBank:JN800042] } & 5005 & 5005 & \text { gtgcc } & \text { gtgcc } & 16465 \\ \text { [GenBank:JN800043] } & 4103 & 4201 & \text { tacct } & \text { tacct } & 13897 \\ \text { [GenBank:JN800044] } & 4094 & 4224 & \text { ctaag } & \text { ctaag } & 13913 \\ \text { [GenBank:JN800045] } & 3103 & 3119 & \text { cattc } & \text { cattc } & 11311 \\ \text { [GenBank:JN800046] } & 3357 & 3384 & \text { aagct } & \text { aagct } & 11887 \\ \text { [GenBank:JN800047] } & 2762 & 2760 & \text { gccag } & \text { gccag } & 11725 \\ \text { [GenBank:JN800048] } & 3928 & 3924 & \text { gagcc } & \text { gagcc } & 14465 \\ \text { [GenBank:JN800049] } & 382 & 382 & \text { caaat } & \text { caaat } & 5164 \\ \text { [GenBank:JN800050] } & 315 & 315 & \text { aagtt } & \text { aagtt } & 5748 \\ \text { [GenBank:JN800051] } & 416 & 419 & \text { tgagt } & \text { tgagt } & 5490 \\ \text { [GenBank:JN800052] } & 385 & 385 & \text { ggtag } & \text { ggtag } & 5208 \\ \text { [GenBank:JN800053] } & 1299 & 1289 & \text { gtggc } & \text { gtggc } & 15080 \\ \text { [GenBank:JN800054] } & 1205 & 1199 & \text { actag } & \text { actag } & 15452 \\ \text { [GenBank:JN800055] } & 1115 & 1116 & \text { tgatg } & \text { tgatg } & 15779 \\ \text { [GenBank:JN800056] } & 1345 & 1343 & \text { ctcac } & \text { ctcac } & 14361 \\ \text { [GenBank:JN800057] } & 1149 & 1147 & \text { gtcat } & \text { gtcat } & 17523 \\ \text { [GenBank:JN800058] } & 804 & 804 & \text { aaac } & \text { aaaac } & 17145 \\ \text { [GenBank:JN800059] } & 793 & 815 & \text { agatc } & \text { agatc } & 12425\end{array}$




\begin{tabular}{|c|c|c|c|c|c|c|c|}
\hline RLG_scTat_3.1 & Gypsy_Tat & [GenBank:JN800060] & 807 & 807 & ggtgg & ggttg & 9569 \\
\hline RLG_scTat_4.1 & Gypsy_Tat & [GenBank:JN800061] & 1096 & 1105 & ttagt & ttagt & 17778 \\
\hline RLG_scTat_5.1 & Gypsy_Tat & [GenBank:JN800062] & 1113 & 1112 & tagcg & tagcg & 10807 \\
\hline RLG_scTat_6.1 & Gypsy_Tat & [GenBank:JN800063] & 458 & 458 & cttgt & cttgt & 9218 \\
\hline RLG_scTat_7.1 & Gypsy_Tat & [GenBank:JN800064] & 698 & 698 & gctct & gctct & 12372 \\
\hline
\end{tabular}
Nome do LTR-RT designado neste artigo, nome pré-existente (ARAUJO et al., 2005b; GARSMEUR et al., 2010), número de acesso do GenBank, tamanho das LTRs 5' e 3 ' e seus respectivos TSDs e o tamanho do element complete, para todas as sequencias de LTR-RT encontrados em cana-de-açúcar. 


\section{APÊNDICE B - Filogenia das superfamílias Gypsy e Copia pela metodologia Maximum}

\section{Likelihood.}

Gypsy

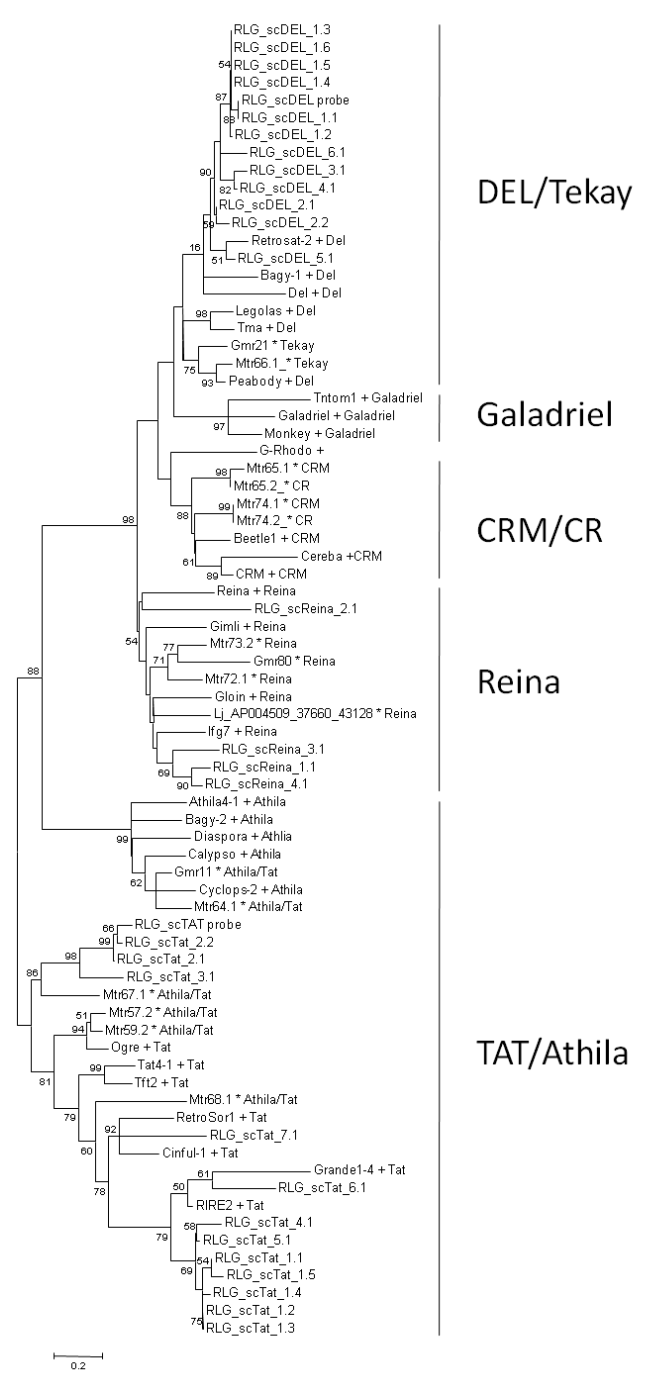

Copia

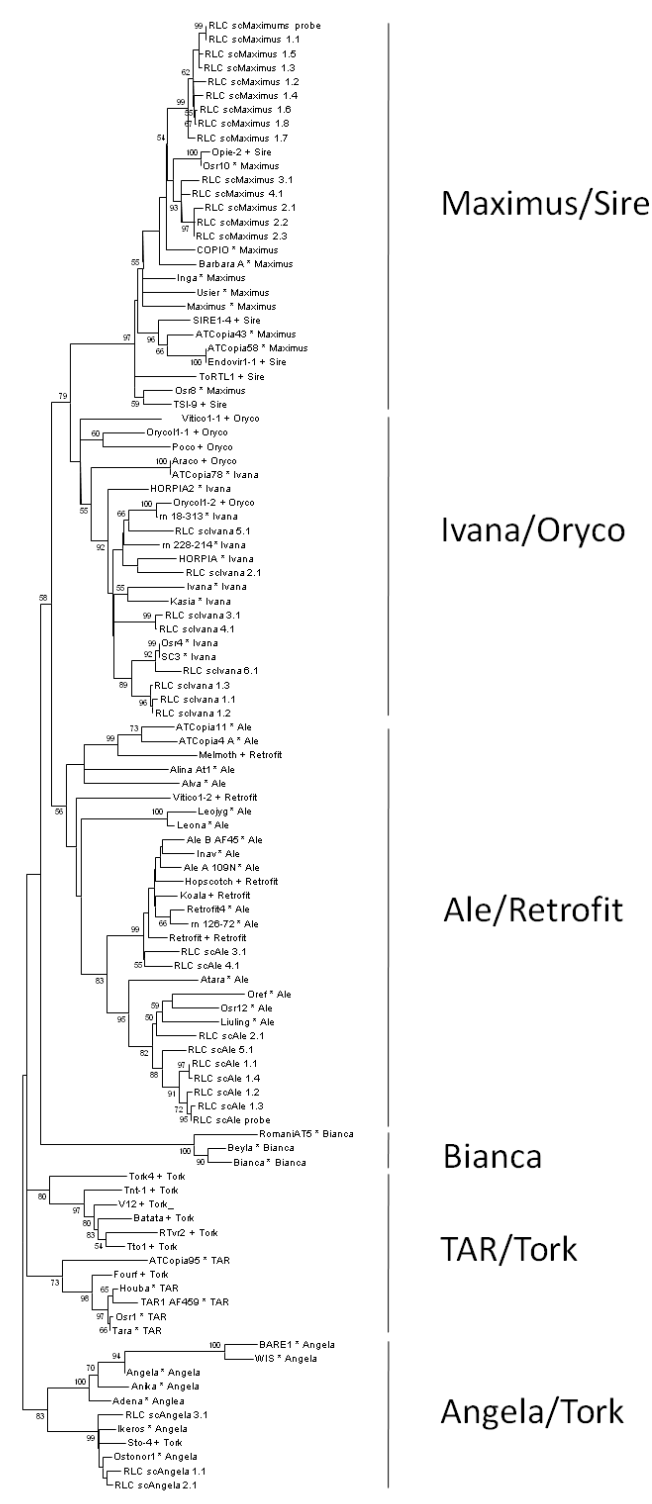

Filogenia das famílias de Gypsy (esquerda) e Copia (direita) baseadas nos alinhamentos de suas transcriptase reversa e gerada pelo método de Maximum Likelihood. A robustez de cada nó foi estimada com um bootstrap de 500 réplicas. Bootstraps com valores inferiores a $50 \%$ não estão apresentados na árvore. 
APÊNDICE C - Mapeamento de sRNAs em cada cópia de cada família de LTR-RT estudada.

scDel_1.1

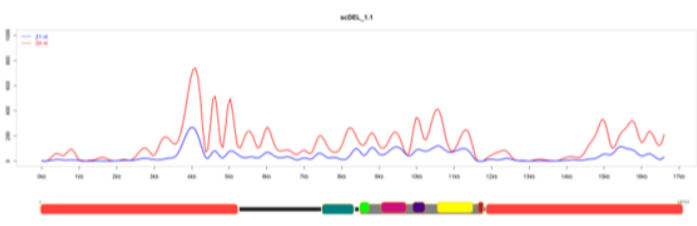

scDel_2.1

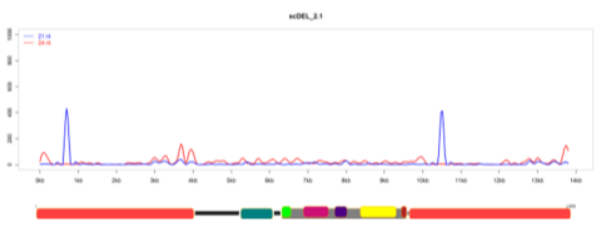

scDel_3.1

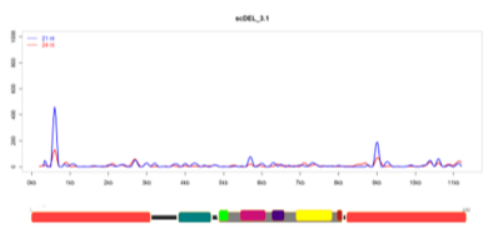

scDel_4.1
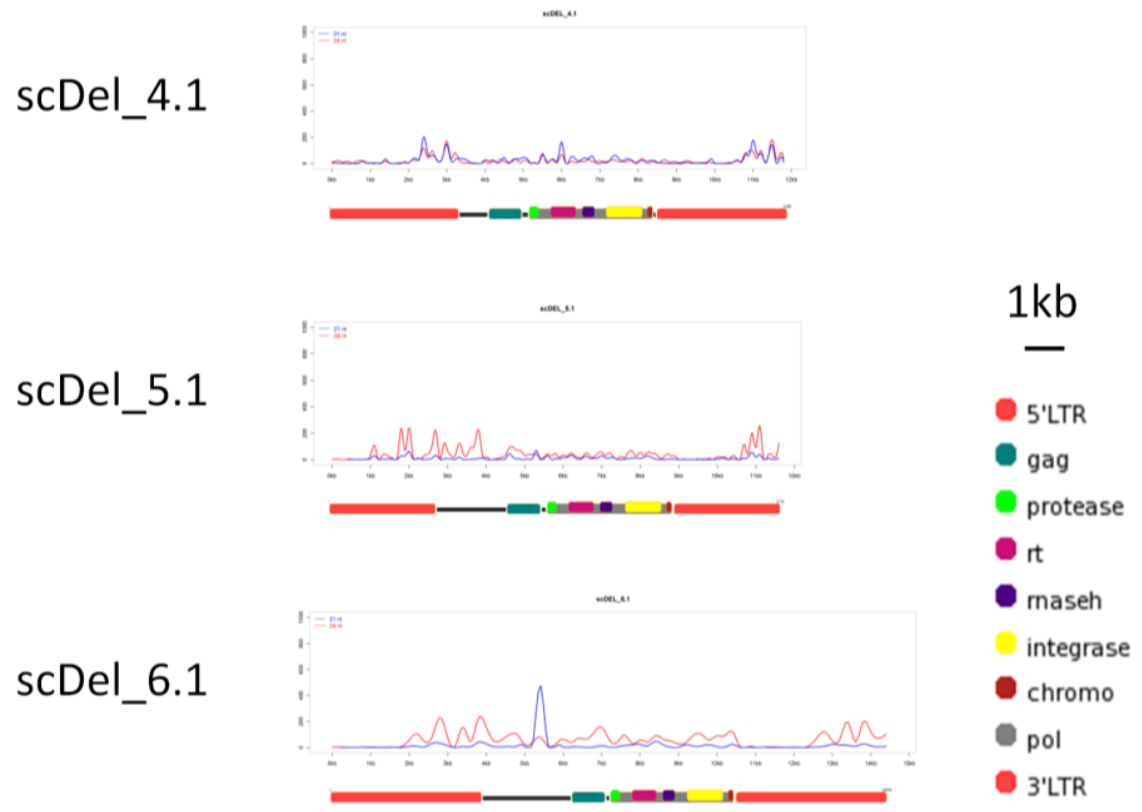


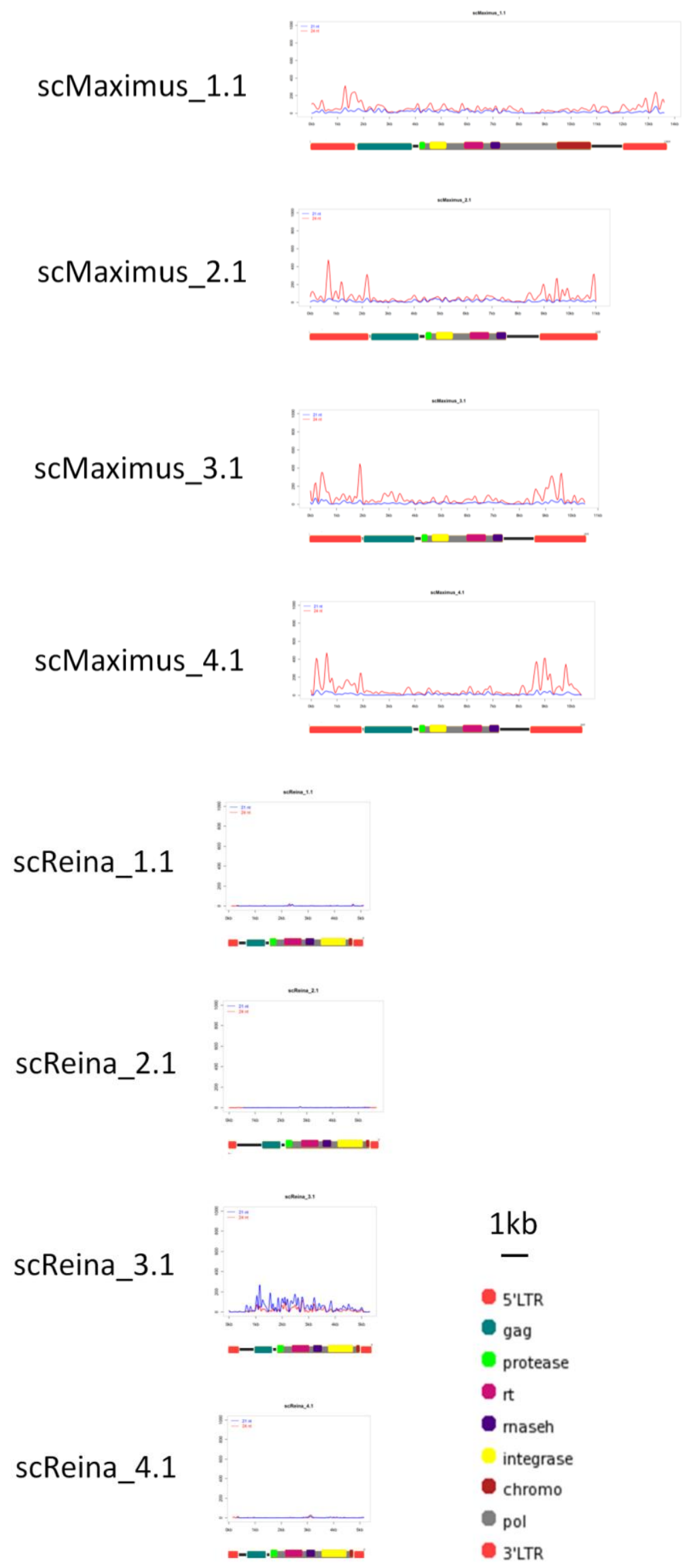




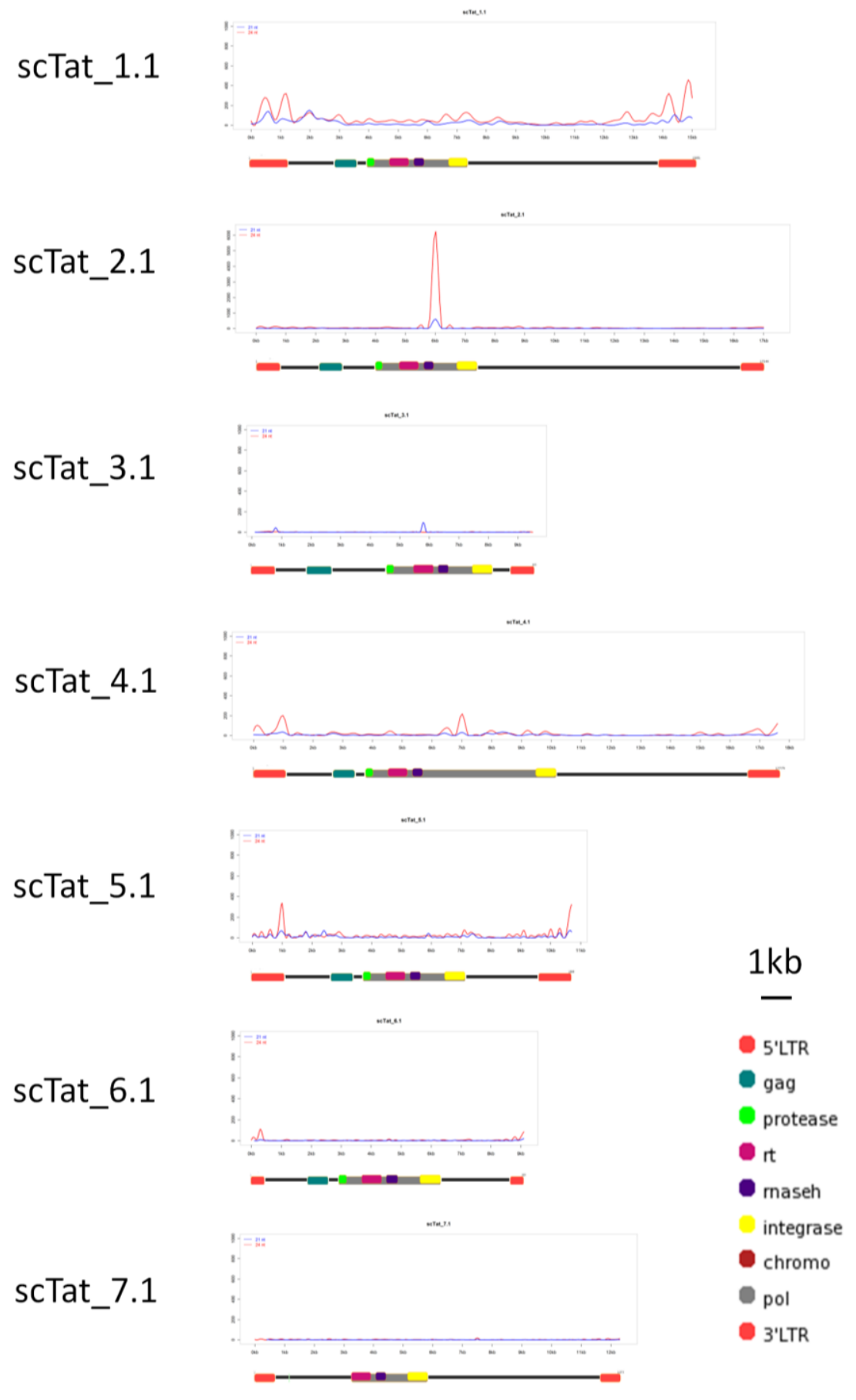




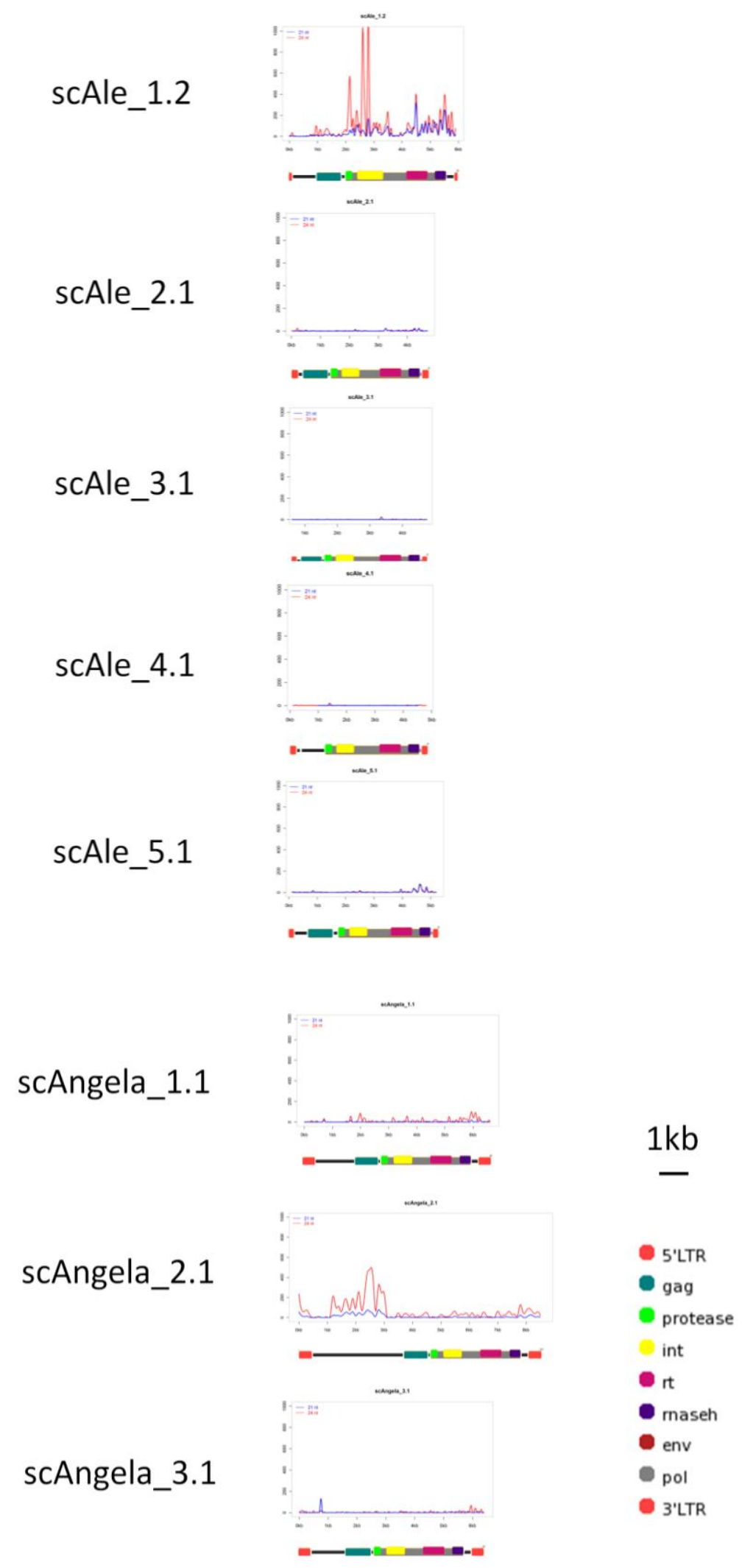




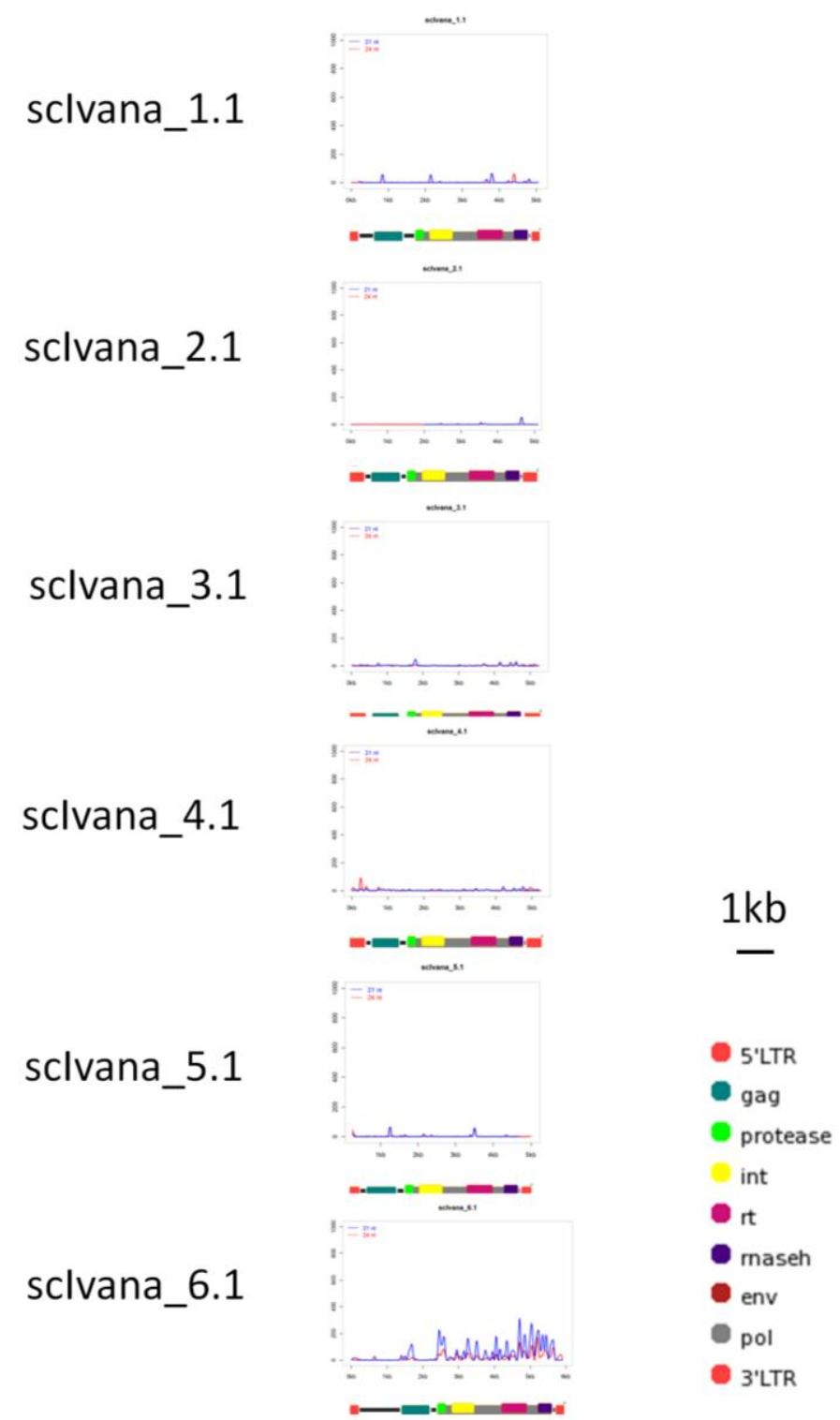

20-22nt sRNAs estão representados por linhas azuis, enquanto 23-25nts RNAs estão representados por linhas vermelhas. 
APÊNDICE D - Contagem de 20-22nt e 23-25nt sRNA para cada família de LTR-RT.

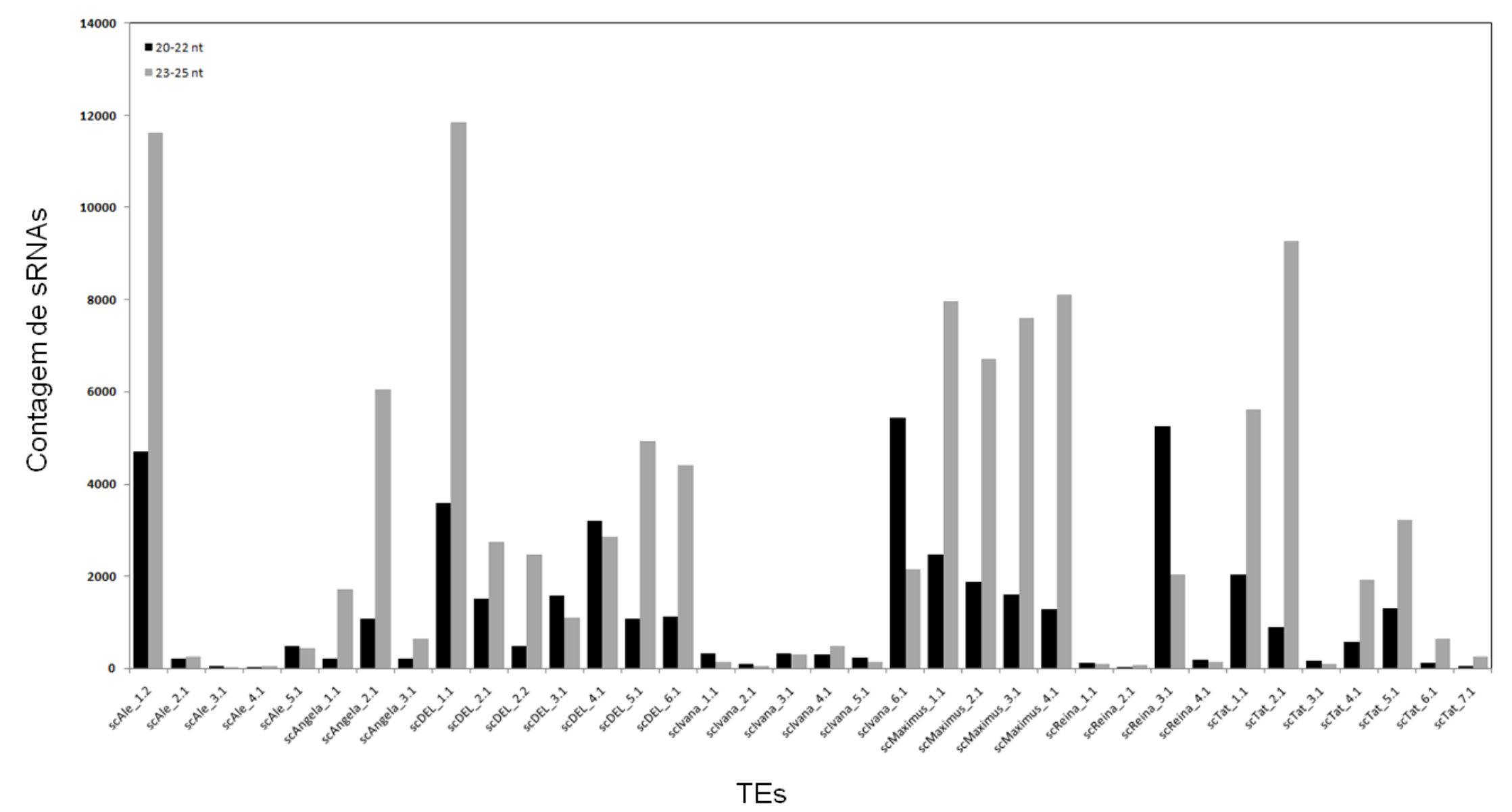

Barras indicam o número de sRNAs de 20-22nt (preto) e 23-25nt (grey) encontrados para cada família de LTR-RT family, com um mismatch máximo de 2nt. 
APÊNDICE E - Famílias a que pertencem os cDNAs previamente estudados de LTR-RTs de cana-de-açúcar.

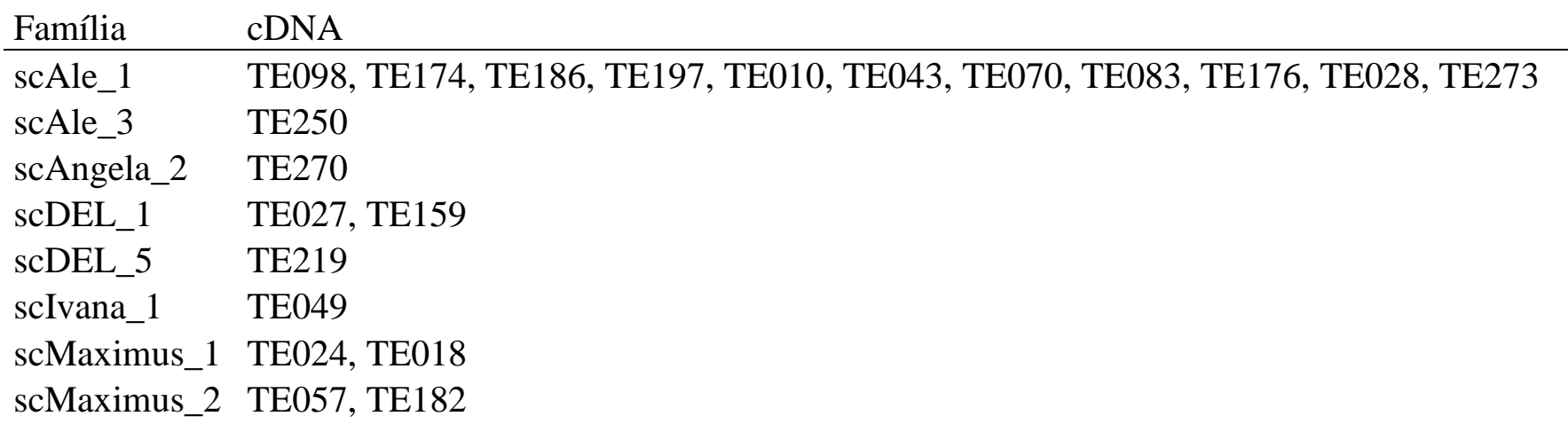


APÊNDICE F - Número total de elementos Del identificados em cada genoma e o número desses elementos que foram utilizados em análises envolvendo as LTRs.

\begin{tabular}{lcc}
\hline Genoma & $\begin{array}{c}\text { Sequências utilizadas } \\
\text { na analise filogenética }\end{array}$ & $\begin{array}{l}\text { Sequências utilizadas em } \\
\text { análises envolvendo as LTRs }\end{array}$ \\
\hline \multicolumn{1}{c}{ Eudicotiledôneass } & 11 & 10 \\
Arabidopsis thaliana & 57 & 43 \\
Medicago truncatula & 1 & 1 \\
Populus trichocarpa & 16 & 15 \\
Vitis vinifera & 33 & 25 \\
Glicine max & & \\
& & \\
Monocotiledôness & 11 & 8 \\
Brachypodium distachyon & 240 & 227 \\
Oryza sativa & 200 & 179 \\
Setaria italica & 548 & 503 \\
Sorghum bicolor & 1315 & 1176 \\
Zea mays & & \\
& 2432 & 2187 \\
Total & & \\
\hline
\end{tabular}

APÊNDICE G - Fig. S2. Conservação dos sítios U5 att do tipo A e B.
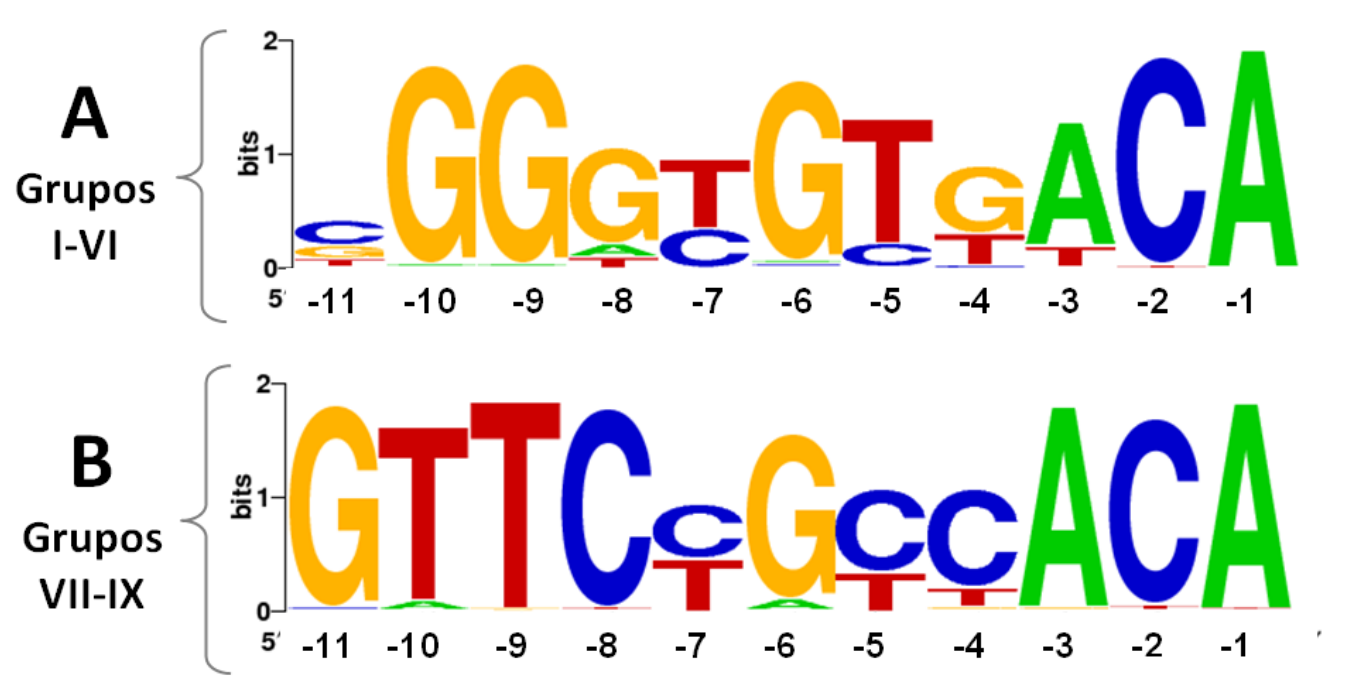

Dois tipos de sítios U5 att foram identificados, A e B. O tipo A foi encontrado nos grupos I-VI, enquanto o tipo B foi encontrado apenas nos grupos VII-IX. A descrição de um logo de conservação foi feita na legenda da Figura 2. 


\section{APÊNDICE H - Lista de artigos publicados ou em preparação.}

The biotechnology roadmap for sugarcane improvement

Carlos T Hotta, Carolina G Lembke, Douglas S Domingues, Edgar A Ochoa, Guilherme MQ Cruz, Danila M Melotto-Passarin, Thiago G Marconi, Melissa O Santos, Marcelo Mollinari, Gabriel RA Margarido, Augusto César Crivellari, Wanderley D dos Santos, Amanda P de Souza, Andrea A Hoshino, Helaine Carrer, Anete P Souza, Antônio AF Garcia, Marcos S Buckeridge, Marcelo Menossi, Marie-Anne Van Sluys, Glaucia M Souza Tropical Plant Biology 3 (2), $75-87$ (2010)

Analysis of plant LTR-retrotransposons at the fine-scale family level reveals individual molecular patterns

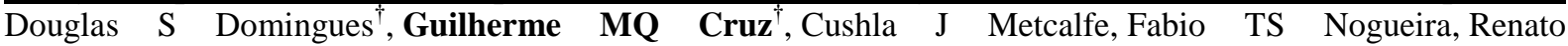
Vicentini, Cristiane de S Alves and Marie-Anne Van Sluys

These authors contributed equally to this work.

BMC genomics 13 (1), 137 (2012)

Mutator system derivatives isolated from sugarcane genome sequence

Manetti M.E. ${ }^{£}$, Rossi. M., ${ }^{\ddagger}$, Cruz G.M.Q. ${ }^{£}$, Saccaro Jr N.L., Nakabashi M., Altebarmakian V., Rodier-Goud M, Domingues D., D’Hont A., Van Sluys, M.A.

${ }^{\mathfrak{f}}$ These authors contributed equally to this work.

Tropical plant biology 5 (3), 233-243 (2012)

Diversification of hAT transposase paralogues in the sugarcane genome

Erika M. de Jesus, Edgar A. O. Cruz, Guilherme M. Q. Cruz, Magdalena Rossi, Paula G. Araújo, Marie-Anne Van Sluys

Molecular Genetics and Genomics 287 (3), 205-219 (2012)

Novel Transposable Elements in Solanaceae: Evolutionary Relationships among Tnt1-related Sequences in Wild Petunia Species

Raquel A. Kriedt, Guilherme M. Q. Cruz, Sandro L. Bonatto, Loreta B. Freitas

Plant Molecular Biology Reporter 32 (1), 142-152 (2014)

Noise or Symphony: Comparative Evolutionary Analysis of Sugarcane Transposable Elements with Other Grasses

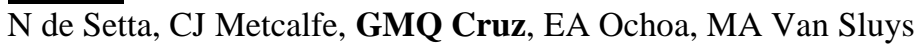

Plant Transposable Elements, 169-192 (2012)

Virus-like attachment sites and plastic CpG islands: landmarks of diversity in plant Del retrotransposons. Guilherme MQ Cruz, Cushla J Metcalfe, Nathalia De Setta, Edgar AO Cruz, Andréia Prata Vieira, Rosario Medina, Marie-Anne Van Sluys

\#Artigo submetido para a revista PLOS One em dezembro de 2013

Building the sugarcane genome sequence for biotechnology and identifying evolutionary trends

De Setta N, Monteiro-Vitorello CB, Metcalfe CJ, Cruz GMQ, Vicentini R, Nogueira FT, Del Bem LE, Campos RA, Nunes SL, Turrini PC, Prata A, Cruz EAO, Corrêa TCS, Hotta CT, Varani AM, Vautrin S, Trindade AS, Vilela MM, Lembke CG, Sato PM, Andrade RF, Nishiyama MYJr, Cardoso-Silva CB, Silva CBC, Scortecci KC, Garcia AA, Kim C, Paterson AH, Berges H, D’Hont A, Souza AP, Souza GM, Vincentz M, Kitajima JP, Van Sluys MA

\#Artigo submetido para a revista BMC Genomics em janeiro de 2014 